High Level Waste Management Division

\title{
High Level Waste System Plan Revision 9 (U)
}

\section{April 1998}

Westinghouse Savannah River Company Savannah River Site

Aiken, SC 29808 


\section{DISCLAIMER}

This report was prepared as an account of work sponsored by an agency of the United States Government. Neither the United States Government nor any agency thereof, nor any of their employees, makes any warranty, express or implied, or assumes any legal liability or responsibility for the accuracy, completeness, or usefulness of any information, apparatus, product, or process disclosed, or represents that its use would not infringe privately owned rights. Reference herein to any specific commercial product, process, or service by trade name, trademark, manufacturer, or otherwise does not necessarily constitute or imply its endorsement, recom. mendation, or favoring by the United States Government or any agency thereof. The views and opinions of authors expressed herein do not necessarily state or reflect those of the United States Government or any agency thereof. 


\section{DISCLAIMER}

Portions of this document may be illegible in electronic image products. Images are produced from the best available original document. 
HLW-OVP-98-0037

\title{
High Level Waste Management Division
}

\section{High Level Waste System Plan Revision 9 (U)}

\author{
Contributors: A. S. Choi \\ P. Paul \\ F. E. Wise
}

Prepared by: Neil Rass

N.R. Davis

$6 / 2 / 98$

HLW System Integration Manager

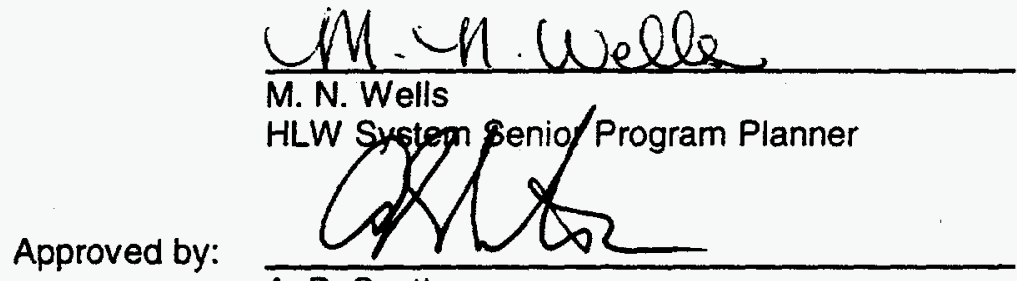

A. B. Scott

Vice President and General Manager

Date

High Level Waste Management Division

Westinghouse Sayannah River Company

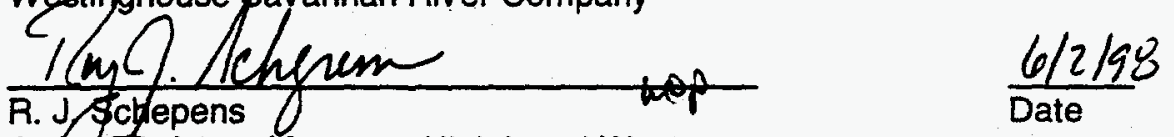

Acting Assistant Manager, High Level Waste

U. \$. Debontringnt of Energy, Sayangah River Field Office
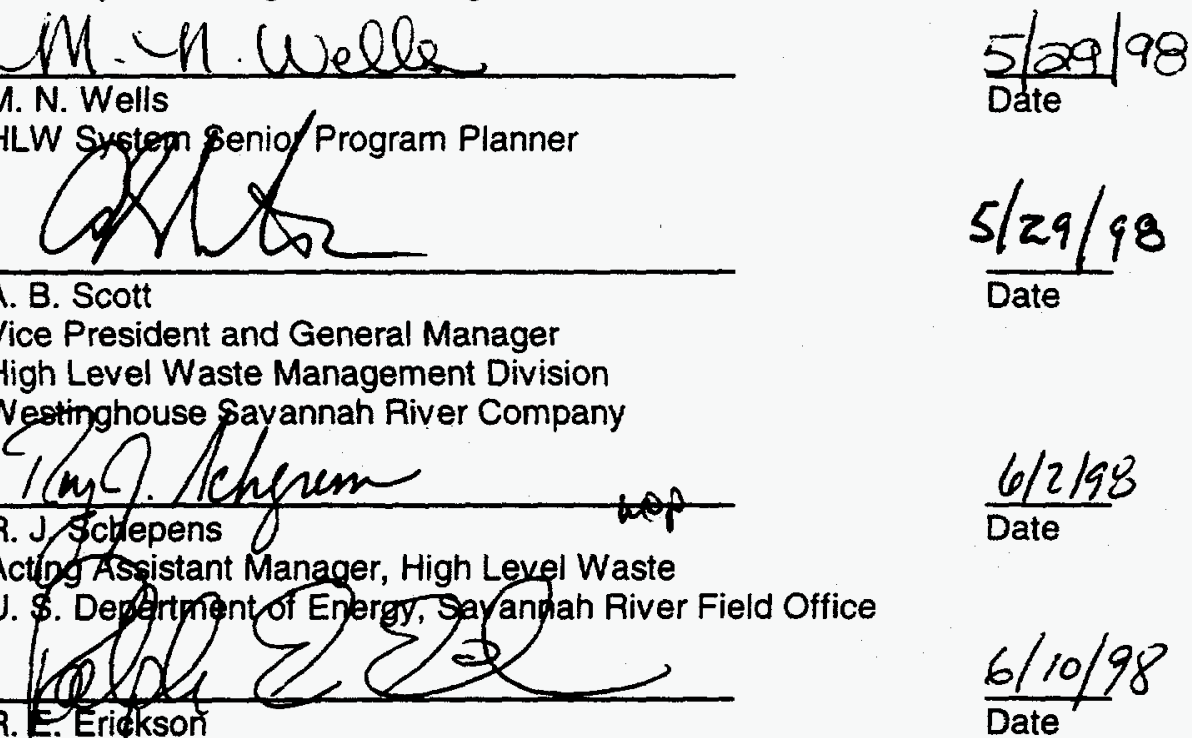

R. E. Eriqkson

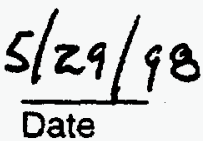

Dilector, Office of Eastern Operations

Environmental Management

U. S. Department of Energy, Headquarters

Prepared for the U. S. Department of Energy under contract no. DE-AC09-96SR18500 
Mr. R. J. Schepens, Acting Assistant Manager

High Level Waste

U. S. Department of Energy

Savannah River Field Office

P. O. Box A

Aiken, SC 29802

Dear Mr. Schepens:

\section{HIGH LEVEL WASTE SYSTEM PLAN, REVISION 9 (U)}

Attached is the final version of the HLW System Plan, Revision 9. The reference date of this System Plan is April 17, 1998. Schedules, forecasted budget, milestones, cost estimates, operational plans and facility status information are current as of that date. Revision 9 analyzes the programmatic and funding requirements to support two cases: a base case showing production of 250 canisters per year, and a comparative case, showing production of 200 canisters per year. The System Plan 250-canister base case will be used as the "Requirements Case" in the next update of the "Accelerating Cleanup: Paths to Closure" plan. It was also used as the basis for the FYOO Out-Year Budget. The 200-canister comparison case aligns with the Site's current target funding level for FY00. Although the 250-canister case requires additional funding in the early years of the program, successful implementation of this case will complete the HLW Program mission five years earlier and yield a life cycle cost savings of $\$ 3.8$ billion.

Questions or requests for additional information regarding this Plan should be directed to S. S. Cathey at $8-3215$, or M. N. Wells at 8-8430 of my staff.

Sincerely,

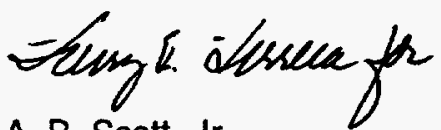

A. B. Scott, Jr.

Vice President and General Manager

High Level Waste Management Division

MNW:mnw/cb

Att. 
THIS PAGE

INTENTIONALLY BLANK 


\section{Table of Contents}

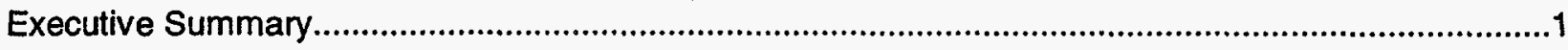

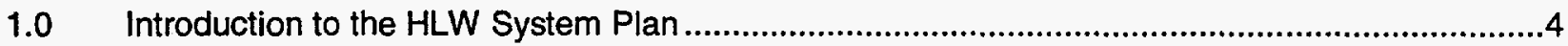

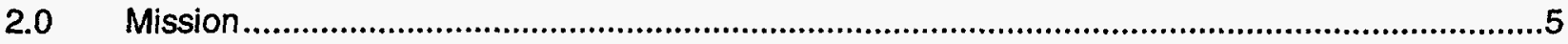

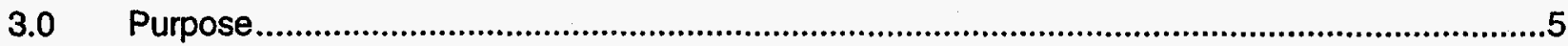

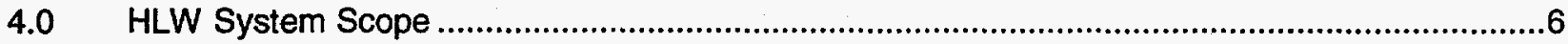

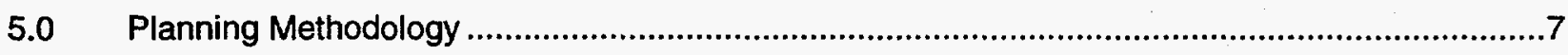

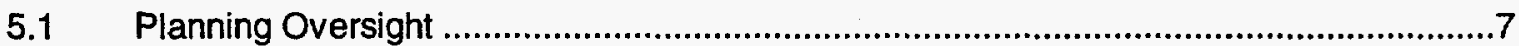

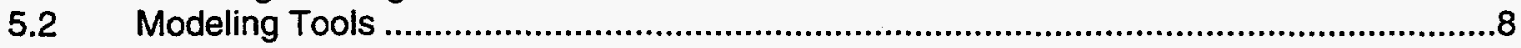

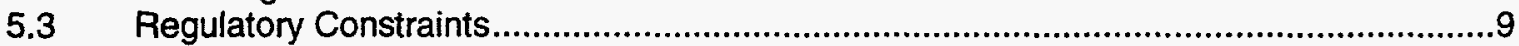

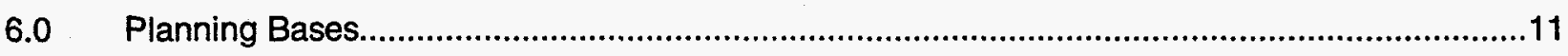

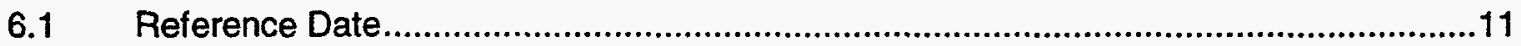

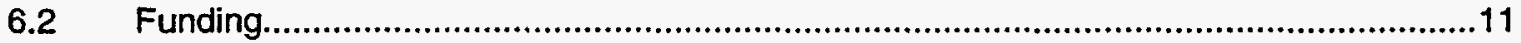

6.3 Key Milestones and Integrated Schedule ..........................................................11

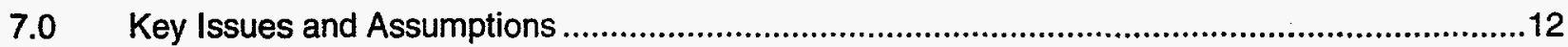

7.1 Accelerating Cleanup Plan: Paths to Closure …......................................................12

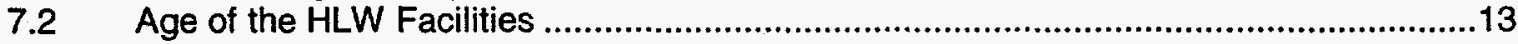

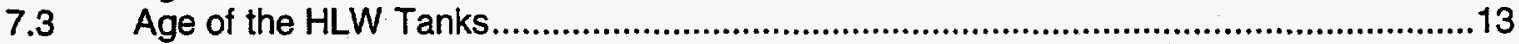

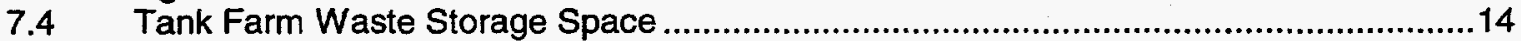

7.5 Transferring Waste Into Old-Style Tanks....................................................................15

7.6 ITP Flowsheet and Resumption of Operations..........................................................15

7.7 TSR Implementation: Scope and Schedule ..............................................................16

$7.8 \quad$ TSR Implementation: Facility Impacts......................................................................18

7.9 Key HLW Processing Parameters Uncertainty .............................................................19

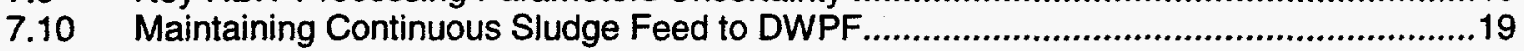

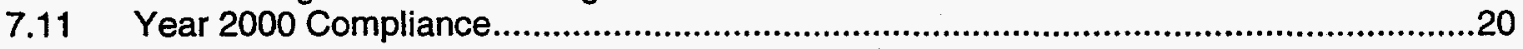

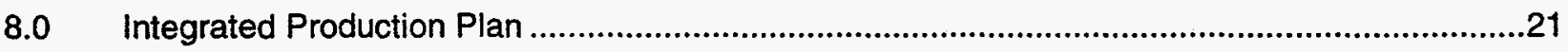

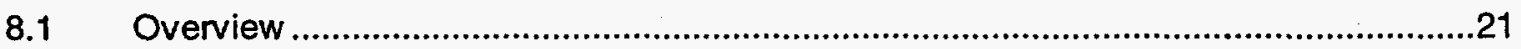

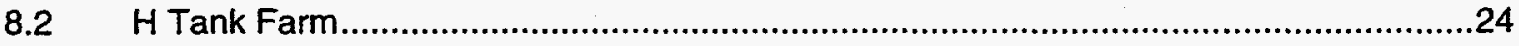

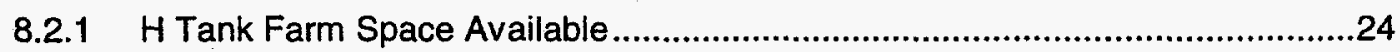

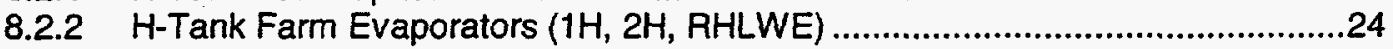

8.2.3 H-Tank Farm Waste Removal Operations ..................................................27

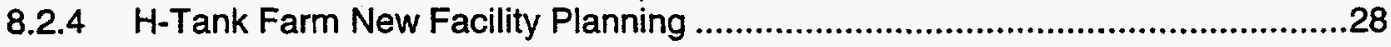




\section{Table of Contents}

8.0 Integrated Production Plan, continued:

8.3 F Tank Farm

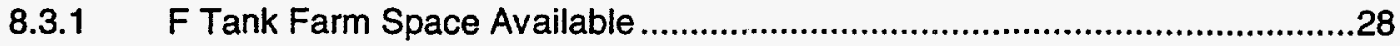

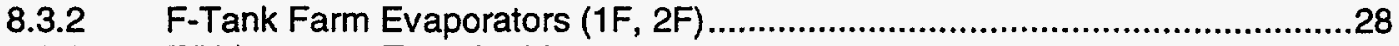

8.3.3 F/H Interarea Transfer Line ................................................................30

8.3.4 F-Tank Farm Waste Removal Operations .....................................................30

8.3.5 F-Tank Farm New Facility Planning .......................................................

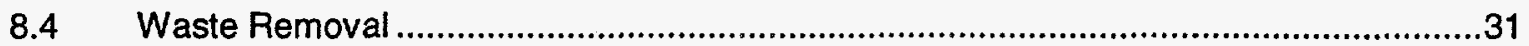

8.4.1 Salt Removal Demonstrations .....................................................................33

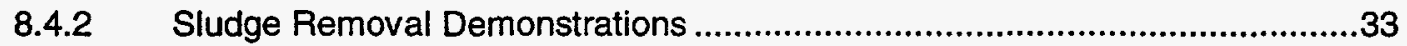

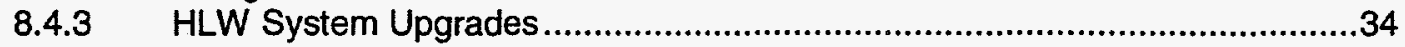

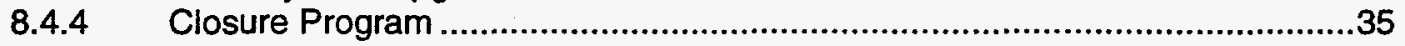

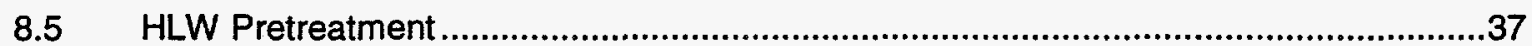

8.5.1 Extended Sludge Processing....................................................................37

8.5.2 Salt Processing: In-Tank Precipitation and Late Wash...................................39

8.6 Defense Waste Processing Facility ....................................................................41

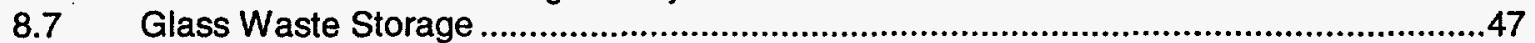

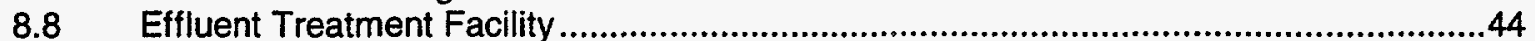

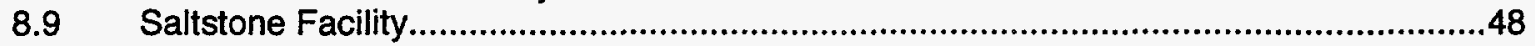

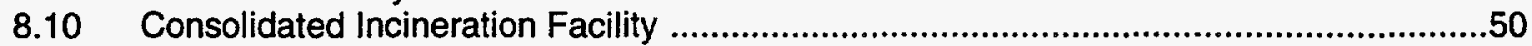

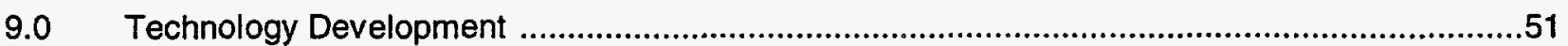

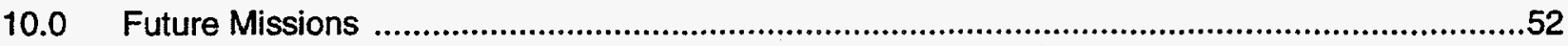

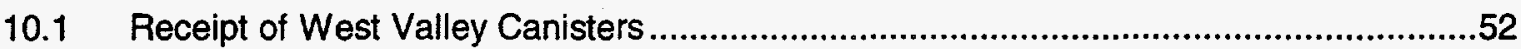

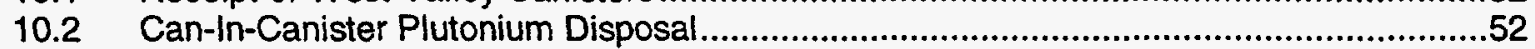

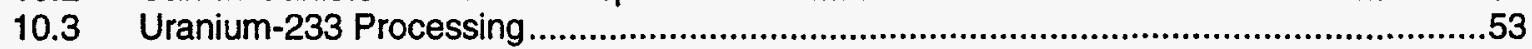




\section{Table of Appendices}
A. Acronyms
B. HLW System Priorities
C. Funding
C.1 Funding (250 cans/yr)
C.2 Funding Comparison (250 cans/yr vs. 200 cans/yr)
D. HLW Projects
E. Waste Removal and Closure Schedule

E.1 Approved FFA Waste Removal Plan and Schedule E.2 Planned Waste Removal Schedule

F. Level 1 HLW System Schedule

G. Production Plan: 250 cans/yr

G.1 Tank Farm Material Balance

G.2 Working Inventory of Tank Space

G.3 Salt Processing

G.4 Sludge Processing

G.5 Canister Storage

H. Simplified HLW System Flowsheet

I. Historical Tank Farm Influents and Effluents

J. Production Plan: 200 cans/yr
J.1 Funding
J.2 Milestones (250 cans/yr vs. 200 cans/yr)
J.3 Level 1 HLW System Schedule
J.4 Tank Farm Material Balance
J.5 Salt Processing
J.6 Sludge Processing
J.7 Canister Storage 
THIS PAGE

INTENTIONALLY BLANK 


\section{Executive Summary}

\section{Introduction}

Revision 9 of the High Level Waste System Plan documents the current operating strategy of the HLW System at SRS to receive, store, treat and dispose of high-level waste. This HLW system is a fully integrated operation that involves safely storing high-level waste in underground storage tanks; removing, pre-treating, and vitrifying this high-level waste; and storing the vitrified waste until it can be permanently disposed of in a Federal Repository. The reference date of Revision 9 is April 17, 1998. Schedules, forecasted budget, milestones, cost estimates and operational plans were current as of that date.

By the end of this fiscal year, over 450 vitrified waste canisters will have been produced and two waste tanks will have been closed. This will leave the tank farms with an estimated $\mathbf{3 4}$ million gallons of waste containing approximately $\mathbf{4 8 0}$ million curies of radioactivity to be disposed of over the next 20 years or so.

Revision 9 of the HLW System Plan analyzes the programmatic and funding requirements to support two cases:

- a base case showing the production of 250 canisters per year

- a comparative case showing a production of 200 canisters per year.

The System Plan 250-canister base case will be used as the "Requirements Case" in the next update of the "Accelerating Cleanup: Paths to Closure" plan. It was also used as the basis for the FYOO Out-Year Budget (OYB). The 200-canister comparison case aligns with the site's current target funding level for FYOO. An evaluation of the two cases gives a clear understanding of the benefits to be achieved if the required incremental funding levels can be obtained to make the 250-canister case possible. The key results of the two cases are shown below:

\section{MILESTONE AND LIFE CYCLE COST COMPARISON: 250 CANS/YR VS. 200 CANS/YR}

\section{Description}

Initiation of Coupled Feed* 24 "Old Style Tanks" Closed

Waste Processing Completed

Waste Processing Facilities Closed

All Canisters Shipped to Repository Life Cycle Cost

\begin{tabular}{c}
250 Canisters/Year \\
\hline FY03* \\
FY14 \\
FY17 \\
FY20 \\
FY25 \\
$\$ 13.6$ Billion
\end{tabular}

200 Canisters/Year FY05*

FY16

FY22

FY25

FY25

* The dates shown for the Initiation for Coupled Feed are based on current In-Tank Precipitation and Late Wash flow sheets and current salt loading levels in DWPF canisters. However, based on the various salt-processing options it may be possible to delay the Initiation of Coupled Feed in the 250 Canister Case until FY05. This may be done either by increasing the salt loading level in DWPF canisters based on the current Waste Acceptance Criteria and/or by modifying the frit composition. The ability to delay the Initiation of Coupled Operations for both the 200 and 250 canister/year production rates is being evaluated along with the salt processing options. The results of this evaluation will be incorporated in the next revision of the HLW System Plan.

To achieve the improved results of the 250-canister-per-year case, additional funding will be required in the early years of the program. The funding differences and scope drivers from FY99 through FY06 are shown below. Note that, although the 250-canister case requires additional funding for 5 years, it then requires less funding. The 250-canister case breaks even with the 200-canister case in FY13 and completes the program with $\$ 3.8$ billion in life cycle cost savings. 
INCREMENTAL COST COMPARISON: 250 CANS/YR VS. 200 CANS/YR

\begin{tabular}{|c|c|c|}
\hline & Incremental Cost (\$M) & Primary Scope Drivers \\
\hline FY99 & 4.2 & - Expedited Sludge Removal Tank Preparations \\
\hline FYOO & 61.3 & $\begin{array}{l}\text { - Expedited Salt Processing Upgrades } \\
\text { - Expedited Sludge Removal Tank Preparations }\end{array}$ \\
\hline FY01 & 37.3 & $\begin{array}{l}\text { - } \quad \text { Expedited Salt Processing Upgrades } \\
\text { - Expedited Sludge Removal Tank Preparations } \\
\text { - } \quad \text { Expedited Glass Waste Storage Building II }\end{array}$ \\
\hline FY02 & 28.1 & - Expedited Glass Waste Storage Building II \\
\hline FYO3 & 29.8 & $\begin{array}{l}\text { - Salt Processing Upgrades Completed Earlier } \\
\text { - Expedited Salt \& Sludge Removal Tank Preparations } \\
\text { - } \quad \text { Expedited Glass Waste Storage Building II }\end{array}$ \\
\hline FY04 & -5.6 & - Glass Waste Storage Building II Completed Earlier \\
\hline FY05 & -17.1 & $\begin{array}{l}\text { - Glass Waste Storage Building II Completed Earlier } \\
\text { - Expedite Saltstone Vault }\end{array}$ \\
\hline FY06 & -42.1 & - Glass Waste Storage Building II Completed Earlier \\
\hline
\end{tabular}

Two major changes have been incorporated into this HLW System Plan:

Re-use of old-style tanks. Transfer of additional waste into several old-style waste tanks is necessary due to the delay in Salt Processing and coupled feed operations resulting from the technical difficulties at In-Tank Precipitation.

A 5,200 total canister count. The estimate of the total canister count has been reduced from 5,900 to 5,200. Three enhancements make this reduction possible:

- The amount of glass placed in each canister is higher than previously estimated.

- Waste loading in glass is higher than previously estimated,

- Waste composition data has been refined to better differentiate between salt and sludge in those tanks that contain significant quantities of both.

The HLW inventory at the time of this plan is projected to produce 5,084 canisters. This reduction in the total number of canisters to be produced will provide significant savings to the government by shortening the duration of the HLW program and thereby reducing HLW life cycle costs, and by reducing the overall cost to store canisters at the Federal Repository.

\section{State of the HLW System}

The status of each key HLW facility is summarized below.

H-Tank Farm: Modifications to the 2H Evaporator were completed to resolve the Potential Inadequacy in Safety Analysis (PISA) related to the source term of the waste in the vessel. The performance of the $2 \mathrm{H}$ Evaporator has greatly exceeded expectations: at the time of this System Plan, the 2H Evaporator had gained $\sim 1,225,000$ gallons of space vs. a pro-rated goal of 977,000 gallons. At this time, $\mathrm{H}$-Tank Farm has $\sim 656,000$ gallons of tank space available. In order to maintain an acceptable level of available tank space until salt processing resumes, $\sim 5,000,000$ gallons of dilute supernate are being retrieved from $\mathrm{H}$-Tank Farm Type III tanks for evaporation in the $2 F$ and RHLWE systems. Evaporation of these dilute wastes is expected to recover $\sim 3,000,000$ gallons of tank space over the period FY98-FY00. Construction and startup testing of the RHLWE remains on schedule to support a startup date of $6 / 30 / 99$. 
F-Tank Farm: At the time of this System Plan, the 2F Evaporator had gained 234,000 gallons of space vs. a pro-rated goal of 251,000 gallons. The evaporator is currently in a four month outage for modifications to ensure compliance with safety basis requirements. The evaporator is expected to resume operations ahead of the scheduled 5/15/98 date. F-Tank Farm has $\sim 664,000$ gallons of tank space available.

Tank Closure: Tanks 17 and 20 operational closure is complete; these are the first two high level waste tanks to be closed in the U.S. Preparations are underway to sample the waste in the Tank 16 annulus to determine if annulus cleaning is required. The first tank cluster will be closed FYO4 (Tanks 17-20). Eleven tanks will be closed by the end of FY06 in the 250 canister/year case, or seven tanks for the 200 canister/year case.

Waste Removal: Construction of waste removal equipment continues on Tanks 8,25 and 29 as well as supporting services in both tank farms. Design was initiated and continues on Tank 11. Routing all signals and controls for Tanks 29-32 and 35-37 to the RHLWE Control Room continues. Maintaining continuous sludge feed to DWPF at a rate of 250 canisters per year requires acceleration of all activities supporting subsequent sludge batch preparation. These activities have taken on a high priority in this System Plan.

Extended Sludge Processing (ESP): Sludge Batch 1A feed from Tank 51 to DWPF continues in support of a canister production rate of 250 cans/yr. In Tank 51, the B-4 slurry pump was replaced. It was the last of the four original pumps to be replaced with the improved version. The Telescoping Transfer Pump was also lowered 30" to enable all of the sludge in Tank 51 above the pump heel to be pumped out. Tank 51 sludge feed to DWPF At the 250 canister/year feed rate, the sludge level in Tank 51 will reach the pump heel in mid-August 1998. Final washing, decanting and settling of Batch 1B in Tank 42 is complete. Pending satisfactory results from the Tank 42 sludge acceptance testing currently ongoing at SRTC, the Tank 42 sludge will be transferred into Tank 51 in July 1998 to provide continuous sludge feed to DWPF.

In-Tank Precipitation (ITP) and Late Wash: The chemistry program to better understand benzene generation, retention and release and loss of cesium decontamination factor progressed to a point where it was decided that the benzene generation rate was too high to ensure that fuel control could be used as a credible defense-in-depth safety feature in Tanks 48 and 49 . Process development work and most field modifications were suspended on January 23,1998. A salt processing Systems Engineering Evaluation is in progress. All known salt processing options will be evaluated against HLW System requirements and the best option will be selected. A draft schedule for the Systems Engineering Evaluation proposed September 30, 1998 as the target date by which the evaluation would be completed and a recommendation submitted to DOE-SR. As this effort has progressed and the scope of the evaluation has become more focused, a final schedule for this effort can be prepared. The final schedule, due to DOE-SR on June 22,1998 , will identify a firm completion date, which may vary slightly from the target September 30, 1998 date originally proposed.

Because the Systems Engineering Evaluation is ongoing at this time, salt processing in this System Plan is based on the existing ITP and Late Wash flowsheet. Further, this System Plan assumes that salt processing will resume in FY02. This is the date by which ITP operations should begin, with DWPF coupled operations starting in $\mathrm{FYO3}$, if the production rate is 250 canisters/year and the sludge:salt ratio in glass is per the historical "recipe." If the production rate is 200 canisters/year, then coupled operations should start no later than FY05. However, based on the various saltprocessing options it may be possible to delay the Initiation of Coupled Feed in the 250 Canister Case until FY05. This may be done either by increasing the salt loading level in DWPF canisters based on the current Waste Acceptance Criteria and/or by modifying the frit composition. The ability to delay the Initiation of Coupled Operations for both the 200 and 250 canister/year production rates is being evaluated along with the salt processing options. The recommendations of the Systems Engineering Evaluation Team will be incorporated in the next System Plan.

Defense Waste Processing Facility (DWPF): Pouring problems experienced in FY97 have been corrected by the installation of the pour spout insert. The insert service life has been acceptable and insert replacement has been performed quickly and without complication. DWPF production 
rates have greatly exceeded expectations. The production rate has averaged about 250 canisters per year since the $4^{\text {th }}$ quarter of FY97. At the time of this System Plan, DWPF had poured 140 canisters vs. a pro-rated goal of 108 (based on pouring at a rate of 200 cans per year). Facility modifications are in progress to support processing of Sludge Batch \#1B sludge, which is expected to begin in July 1998.

Glass Waste Storage Building (GWSB): At the time of this System Plan, 308 glass canisters are stored in GWSB \#1. This represents approximately $14 \%$ of GWSB\#1 available 2,159 canister capacity. Activities are underway to repair the shield plugs for approximately 450 (presently unused) canister storage locations.

Sailtstone: Saltstone will process approximately 300,000 gallons of Tank 50 waste in FY98. In FY99, Saltstone will be placed in partial lay-up mode, pending resumption of salt processing. Key Saltstone personnel will be cross-trained to perform tasks at other SRS facilities while Saltstone is in lay-up.

Effluent Treatment Facility (ETF): The available waste in Tank 50 (approximately 300,000 gallons) will be fed to Saltstone and processed in FY98. This will create sufficient space in Tank 50 to store approximately 4-5 years' worth of ETF evaporator concentrate, pending resumption of salt processing.

Consolidated Incinerator Facility (CIF): CIF began radioactive operations in April 1998 and is currently processing backlogged non-PUREX legacy wastes in support of a Site Treatment Plan commitment to treat $50 \%$ of the non-PUREX legacy mixed wastes by $4 Q$ FY 98 .

\subsection{Introduction to the HLW Svstem Plan}

This Plan describes the strategy for the integrated startup and operation of the HLW System based on allocation of available and projected resources in support of processing 250 canisters per year. The text of the System Plan and Appendices C-G support the 250 canister case. In addition, this System Plan includes pertinent production planning data in Appendix $J$ in support of a reduced production rate of 200 canisters per year. This System Plan is developed in conjunction with the budget planning process. This revision supports the FYOO Outyear Budget and will be used as a basis for the next update of the "Accelerating Cleanup: Paths to Closure" document.

The HLW System planning bases are described in Sections 1.0-6.0. Key issues and assumptions are described in Section 7.0. The production plan supporting 250 canisters per year is described in detail in Section 8.0. Two new sections, Sections 9.0 and 10.0, have been added to highlight technology development needs and potential future missions for the HLW System. The Appendices include supporting tables and figures. Appendix A provides a list of acronyms, and Appendix $H$ shows a simplified HLW process flowsheet. These appendices should be particularly useful to those who are not familiar with this Plan. A new appendix, Appendix I, has been added to this System Plan to provide perspective on changes in Tank Farm influents and effluents from 1954 to the present.

One goal of the planning process is to continuously improve the HLW System Plan to better serve the needs of stakeholders. Revision 9 of this Plan incorporates several improvements since Revision 8:

- ProdMod, the integrated linear programming computer simulation of the HLW System using Aspen Speedup ${ }^{(\mathrm{R})}$ software, has been modified to enable planners to incorporate inter-tank transfers and evaporation of backlogged wastes, which are now key activities in HLW production planning;

- Both ProdMod and CPES now use the Waste Composition Database as their sole source of waste tank data;

- All ten sludge batches have been modeled in CPES and individually optimized to maximize waste loading and minimize the number of canisters produced; 
- Sludge Batch compositions have been refined to accommodate DWPF processing concerns related to mercury and uranium;

- An improved system for communications has been established between the High Level Waste Management program and the Nuclear Material Stabilization program to improve forecasting.

Several significant activities are ongoing at this time. The Systems Engineering Evaluation of salt processing flowsheet modifications is in progress, and impacts to related facilities are being assessed. The FYOO Outyear Budget is being developed at this time. HLWMD personnel are also supporting activities that could lead to new missions for SRS. DOE-EM Integration activities could lead to temporary storage of approximately 300 glass canisters from the West Valley site at DWPF's Glass Waste Storage Building. DOE-MD program activities include possible implementation of a can-in-canister program at DWPF for disposition of surplus plutonium.

\subsection{Mission}

The mission of the High Level Waste System is to:

- Safely store the existing inventory of DOE high level waste;

- Support critical Site production and cleanup missions by providing tank space to receive new waste;

- Volume reduce and thereby stabilize high level waste by evaporation;

- Pretreat high level waste for subsequent treatment and disposal;

- Immobilize the low level liquid waste resulting from HLW pre-treatment and dispose onsite as Saltstone grout;

- Immobilize the high level liquid waste as vitrified glass, and store the glass canisters onsite until a Federal Repository is available;

- Retire and close HLW tanks and support systems per regulatory-approved approach; and,

- Ensure that risks to the environment and to human health and safety posed by high level waste operations are either eliminated or reduced to acceptable levels.

That part of the HLW Mission that supports other Site Missions remains a high priority. The Defense Nuclear Facilities Safety Board (DNFSB) 94-1 document contains nine distinct recommendations, the first of which is:

"That an integrated program plan be formulated on a high priority basis, to convert within two to three years the materials addressed in the specific recommendations below, to forms or conditions suitable for interim storage."

The Savannah River Site (SRS) plan to address this recommendation is the Integrated Nuclear Materials Management (INMM) Plan. A detailed high level waste system operating plan that supports all aspects of the HLW Mission is shown in Appendix G.

\section{$3.0 \quad$ Purpose}

The purpose of this HLW System Plan is to document currently planned HLW operations from the receipt of fresh waste through the operation of the DWPF and Saltstone until all HLW has been vitrified, all HLW facilities have been closed, and all glass canisters have been shipped to the Federal Repository. This document is a summary of the key planning bases, assumptions, limitations, strategy and schedules for facility operations needed to support the FYO0 Outyear Budget. This System Plan will also be used as a base document for developing future budget plans, for adjusting individual project baselines to match projected funding, and to project the Site's ability to support the approved Federal Facilities Agreement (FFA) Waste Removal Plan and Schedule. 


\subsection{High Level Waste System Scope}

Key HLW facilities and supporting projects are grouped by function in the "Accelerating Cleanup:Paths to Closure" and FYOO Outyear Budget documents as shown below. The Effluent Treatment Facility and the Consolidated Incineration Facility are included because of the supporting roles they play for the HLW System.

- SR-HLO1: H-Tank Farm

H-Area Tank Farm

2H Evaporator

Replacement High Level Waste Evaporator Project

- SR-HLO2: F-Tank Farm

F-Area Tank Farm

2F Evaporator

$F / H$ inter-Area Line

- SR-HL03: Waste Removal Operations and Tank Closure

Waste Removal operations

Tank Closure projects

Facility Decontamination and Decommissioning

- SR-HL04: Waste Pretreatment

Extended Sludge Processing Facility

Salt Processing Facility (currently includes the In-Tank Precipitation and Late Wash Facilities)

- SR-HL05: Vitrification

Defense Waste Processing Facility

Replacement Melter projects

Failed Equipment Storage Vault projects

- SR-HL06: Glass Waste Storage

Glass Waste Storage Building operations

Glass Waste Storage Building \#2 construction

- SR-HL07: Effluent Treatment Facility

- SR-HL08: Saltstone

Saltstone Facility

Saltstone Vaults \#1 and \#4

Saltstone Vault projects

- SR-HL09: Tank Farm Service Upgrades

- SR-HL10: H-Tank Farm Storm Water System Upgrades

- SR-HL11: Tank Farm Support Services F Area 
- SR-HL12: High Level Waste System Upgrades

Waste Removal project

Vitrification upgrades

Precipitate upgrades

Piping upgrades (H-Tank Farm East Hill)

- SR-SW01: Consolidated Incineration Facility

The inter-relationships of these facilities and projects are shown in Appendix $H$, Simplified HLW Flowsheet Diagram.

\subsection{Planning Methodology}

Operation of the HLW System facilities is subject to a variety of programmatic, regulatory and process constraints as described below.

\subsection{Planning Oversight}

Some uncertainty is inherent in this Plan. Lack of actual operating experience in the new processes, as well as emergent budget issues, changes to Canyon production plans, evolution of Site Decontamination \& Decommissioning initiatives, and other factors preclude execution of a "fixed" plan. Therefore, DOE Headquarters (DOE-HQ), DOE Savannah River (DOE-SR) and Westinghouse Savannah River Company (WSRC) personnel are continuously evaluating the uncertainties in the Plan and incorporating changes to improve planning and scheduling confidence. WSRC refines and updates this Plan in conjunction with facility operations planning and budget planning.

The HLW Steering Committee provides the highest level of oversight of the HLW System. This Committee consists of members from DOE-HQ, DOE-SR, and the WSRC HLWM Division. The Committee meets periodically to formally review the status and operational plan for the HLW System. The HLW System Plan is approved by DOE-HQ, DOE-SR, and WSRC HLWMD.

The HLW Program Board is a WSRC committee that provides oversight and approval of the HLW System Plan and the schedules contained therein which form the schedule and cost "baseline" for the overall program. Maintenance of the baseline is controlled via a formal change control process.

The Technical Oversight Steering Team (TOST) is comprised of senior WSRC professionals and managers from HLW Engineering, the Savannah River Technology Center, and HLW Program Management, and provides oversight for resolution of technical issues within the HLWMD.

The weekly HLW Interface Meeting among HLWMD Facility Managers and others ensures that near-term activities impacting multiple facilities are closely coordinated to maximize effective allocation of resources.

The High Level Waste Management Technology Program Plan (TPP) describes the integrated technology program plan for the SRS HLW System. The program is based upon the specific needs of the HLW System and is organized following system engineering functions. Specific tasks, funding, deliverables, and milestones are presented for each fiscal year; the plan is updated and issued annually. For additional information on current and planned activities, refer to Section 9.0, Technology Development.

Waste Acceptance Criteria are in place for all waste-receiving facilities. Influent waste streams must be compatible with existing equipment and processes, must remain within the safety envelope, and must meet downstream process requirements. 


\section{$5.2 \quad$ Modeling Tools}

WSRC uses a family of computer simulations to model the operation of the HLW System. Each model is designed to address different aspects of long range production planning. WSRC uses these models interactively to guide long-range production planning.

The Waste Characterization System (WCS) documents the composition of the waste in each of the $51 \mathrm{HLW}$ tanks. Sludge, salt and supernate are characterized separately. The data encompass 41 radionuclides, 38 chemical species, and 23 other waste characteristics, and are derived from a multitude of monthly reports, waste sampling results, Canyon process records and solubility studies. The Waste Characterization System represents the best compilation of SRS HLW characterization to date, and provides a sound basis for production planning analyses.

The Chemical Process Evaluation System (CPES) is a steady-state model originally developed as a design document for DWPF. The strength of this model is the size of the database it can manage. The current version of CPES tracks 183 chemical compounds in 1,750 process streams connecting over 700 unit operations. Its output consists of a complete tabular material balance for all chemical compounds in each process stream. CPES models waste processing operations for each of the ten sludge macro-batches. Because the composition of sludge varies widely from tank to tank, CPES uses tank-specific sludge composition data, as defined by WCS. However, the composition of salt wastes are fairly uniform, so CPES assumes all salt wastes are blended into an "average salt" composition. A new subroutine was recently created, tested and installed that enables CPES to read waste composition data directly from the Waste Characterization System. Close-coupling of these two models is a key planning improvement for the HLWMD, because it allows planners to easily determine how changes in waste composition data will impact sludge batches and subsequent processing in DWPF. In addition, all ten sludge macro-batches have been modeled through CPES, and all ten are expected to produce acceptable glass.

In addition to its on-line role predicting glass quality in DWPF, the Product Composition Control System (PCCS) is also used off-line to verify that the tank farm waste blends modeled by CPES will be processable in DWPF and will produce acceptable glass. PCCS examines glass property constraints, including liquidus temperature, viscosity, durability, homogeneity, solubility, alumina content, and frit content. PCCS also determines the optimum glass blend to maximize waste loading in glass thereby minimizing canister production for each sludge macro-batch. ESP sludge washing and aluminum dissolution endpoints are established based on CPES and PCCS analyses.

The HLW Integrated Flowsheet Model (HLWIFM) is a non-linear, dynamic simulation in Speedup ${ }^{R}$ software that addresses daily variability over a planning period of approximately 3 years. HLWIFM can model transient waste processing conditions (such as tank levels, temperatures or curie content) against known processing constraints (such as safety parameters, source term limits, operations limits, and regulatory permit requirements).

To expedite modeling of different production planning scenarios, the individual facility modules of the HLWIFM can be run independently. The results of these facility-specific runs are available in seconds, not hours, and are used to optimize facility operations. They are also useful as "real-time" predictive and diagnostic tools while the facility is operating. Facility-specific models have been developed for ITP, ESP, the evaporators and DWPF. HLWIFM also uses the Waste Characterization System as its source of waste data.

The Production Model (ProdMod) is a linear equation model that uses the same Speedup ${ }^{\mathrm{B}}$ software as HLWIFM. The linear equations used in ProdMod enable it to calculate in monthly and annual increments to the end of the program, with a run time of about one minute. This enables planners to quickly evaluate different operating scenarios while still tracking key parameters. ProdMod tracks three key waste constituents: 1) sodium, because it drives the sludge washing operation in ESP; 2) potassium, because it determines the amount of precipitate produced by salt processing; and 3) cesium, because many source term limits are based on cesium concentrations. ProdMod uses the Waste Characterization System as its source of waste data. 
The HLW System Plan Cost Model is based on fixed and variable costs. Fixed costs are those costs required to keep a facility in a "hot standby" mode, in which the facility is fully manned with a trained workforce ready to resume production immediately. Variable costs are those costs that vary with production, including: raw materials, repetitive projects such as outfitting tanks with waste removal equipment, replacement glass melters, Failed Equipment Storage Vaults, Saltstone Vaults, some Capital Equipment, etc. Variable costs go to zero if production is zero. The Cost Model is used to determine the long-term cost impacts of accelerating or delaying HLW production schedules.

The WCS, CPES, PCCS, ProdMod and the Cost Model were used to generate the production planning data contained in the appendices of this System Plan.

\subsection{Regulatory Constraints}

There are numerous regulatory laws, constraints and commitments that impact HLW System planning. The most important ones are described below.

The Federal Facility Agreement (FFA) was executed January 15, 1993 by DOE, the Environmental Protection Agency (EPA) and the South Carolina Department of Health and Environmental Control (SCDHEC). It became effective August 16, 1993. The FFA provides standards for secondary containment, requirements for responding to leaks, and provisions for the removal from service of leaking or unsuitable HLW storage tanks. Tanks that do not meet the standards set by the FFA may be used for the continued storage of their current waste inventories, but these tanks must be placed on a schedule for removal from service. The "F/H Area High Level Waste Removal Plan and Schedule (WRP\&S)," submitted to Regulators on November 10,1993, showed specific start and end dates for the removal from service of each non-compliant tank, and committed SRS to remove the last non-compliant tank from service no later than FY28. The order in which the tanks were removed from service was consistent with sludge batch compositions at the time. The 1993 WRP\&S stated "removal from service" included bulk waste removal and water washing. Tank closure was not envisioned.

In January 1996, DOE began efforts to close Tanks 20 and 17. This was the first time any facility in the U.S. had tried to close a high level waste tank, and no specific regulations for the activity existed. SCDHEC and EPA worked closely with DOE to incorporate appropriate aspects of the Clean Water Act and RCRAVERCLA. Given this new set of tank closure requirements, and other changes that had occurred in sludge batch compositions, a different waste tank schedule emerged. In this schedule, waste removal was planned by groupings of closely-located tanks, such that an entire tank grouping could be emptied in a few years and the group made available for closure. This schedule showed proposed waste removal and closure dates of all 24 non-compliant tanks by 2009 .

In December 1996, DOE submitted the HLW Tank Systems Closure Plan to SCDHEC. The Closure Plan included both the original 1993 schedule, and the newer 1996 schedule. DOE formally requested approval of the 1993 version, stating the 1996 version was for planning purposes only.

By the end of July 1997, DOE had successfully closed Tank 20, and closure of Tank 17 was in progress. In early August 1997, SCDHEC learned that anticipated DOE budget cuts could defer planned tank closure activities for years. Concerned, SCDHEC sent a letter to DOE. The letter stated "SCDHEC cannot approve" the 1993 version of the WRP\&S, and requested DOE to "submit to EPA and SCDHEC for review and approval a revised WRP\&S that is consistent with the three party consensus tank closure strategy outlined in the Program Plan." In subsequent discussions, SCDHEC stressed their interpretation of "removal from service" as tank closure, and expressed their desire for a tank closure schedule. DOE responded by proposing a new WRP\&S. The new schedule includes several features that distinguish it from earlier submittals. It includes closure dates for all 24 non-compliant tanks, and it addresses closing tanks in groupings to the extent that waste characteristics permit. It clearly shows that Tanks 4-8 may be emptied and refilled with concentrated waste, in the event that budget shortfalls or technical uncertainties preclude salt processing for several years. And it includes some contingency to accommodate technology developments for closing Type I and Type II tanks. Nevertheless, the proposed schedule shows an average improvement of 6 years per tank compared to the 1993 WRP\&S. All old-style tanks will be closed by the end of FY22. The proposed WRP\&S was transmitted to SCDHEC and EPA on 
January 15, 1998, and was approved by SCDHEC on February 26, 1998. The approved WRP\&S is an enforceable commitment from DOE to SCDHEC and EPA. Refer to Appendix E.1 to see the approved schedule.

The National Environmental Policy Act (NEPA) requires federal agencies to assess the potential environmental impacts of constructing and operating new facilities or modifying existing facilities. Four NEPA documents directly affect the HLW System and support the operating scenario described in this Plan:

- DWPF Supplemental Environmental Impact Statement;

- Waste Management Environmental Impact Statement;

- Interim Management of Nuclear Materials (IMNM) Environmental Impact Statement;

- Environmental Assessment (EA) for the Closure of the High Level Waste Tanks in F- \& HAreas at the Savannah River Site.

The Site Treatment Plan (STP) for SRS describes the development of treatment capacities and technologies for mixed wastes. This allows DOE, Regulatory Agencies, the States and other stakeholders to efficiently plan mixed waste treatment and disposal by considering waste volumes and treatment capacities on a national scale. The STP identifies vitrification in DWPF as the preferred treatment option for treating SRS liquid high level waste, and it identifies incineration followed by stabilization in the CIF as the preferred treatment option for many mixed wastes.

DWPF has met its STP commitments to submit permit applications, enter into contracts, initiate construction, conduct systems testing, commence operations, and submit a schedule for processing backlogged and currently generated mixed waste. In the schedule submitted to SCDHEC on 5/21/96, SRS committed that:

"... After the startup period is complete and DWPF begins full operation, the maintenance of an average of 200 canisters of processed glass per year will be required in order to meet the schedule for removal of backlogged and currently generated waste inventory by the year 2028..."

The production plan described in this System Plan meets this STP commitment.

CIF has met its STP commitments to submit permit applications, enter into contracts, initiate construction, conduct systems testing, and begin operations. The STP includes the following commitment for CIF:

"Submit an LDR waste processing rate schedule for the CIF within 180 days after commencing operations, including the time necessary to prepare or repackage certain mixed waste streams."

This commitment was met when SRS submitted a schedule on October 17, 1997. The schedule commits to a processing completion milestone and several intermediate milestones, based on mixed waste that were in RCRA permitted or interim status facilities as of 9/30/97. Incinerable mixed waste received at RCRA storage facilities after that date are not included in the schedule, but these wastes will be accumulated and burned in the appropriate CIF campaign (listed vs. characteristic). Nearterm schedule commitments for CIF include:

"Complete processing of $50 \%$ of backlogged non-PUREX SRS mixed wastes by $4 Q$ federal FY98."

"Submit RCRA Part B permit or permit modification for pre-treatment of non-PUREX SRS mixed wastes by $1 Q$ federal FY2002."

"Complete processing of $50 \%$ of the backlogged PUREX waste by $4 Q$ FY2009." 
Receipt and burning of offsite wastes will be reviewed on a case-by-case basis, and requests will be filed with SCDHEC as required by Consent Order 95-22-HW. Offsite quantities are expected to be small, and thus their incorporation should have negligible impact on the treatment schedule for SRS mixed waste.

\subsection{Planning Bases}

\subsection{Reference Date}

The reference date of this Plan is April 17, 1998. Schedules, forecasted budget, milestones, cost estimates and operational plans were current as of that date.

\section{$6.2 \quad$ Funding}

The funding required to support this Plan is shown in Appendix $C$ by individual projects and is based on the funding required to execute either of the two cases. This is different from previous Plans where budget targets were set and the Plan was developed based on the budget targets. The funding required to support the 200 canister/year case is shown in Appendix J.1.

\subsection{Kev Milestones and integrated Schedule}

Key milestones relate to the processes required to remove waste from storage, process it into glass or saltstone grout, and close HLW facilities. Key milestones shown below are supported by the budget as described in Section 6.2. Dates shown in bolded italics are actual dates.

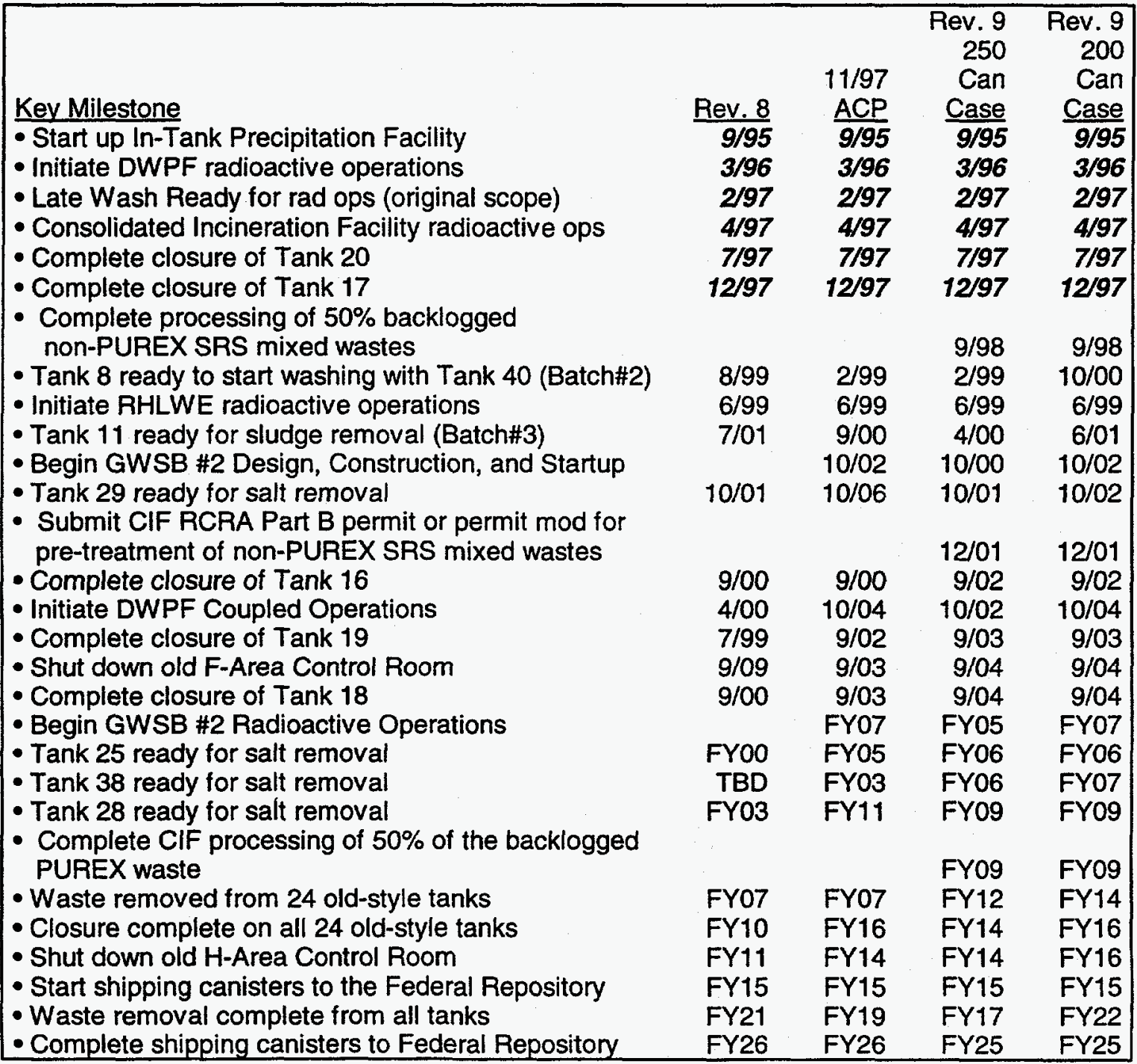


* The dates shown for the Initiation for Coupled Feed are based on current In-Tank Precipitation and Late Wash flow sheets and current salt loading levels in DWPF canisters. However, based on the various salt-processing options it may be possible to delay the Initiation of Coupled Feed in the 250 Canister Case until FY05. This may be done either by increasing the salt loading level in DWPF canisters based on the current Waste Acceptance Criteria and/or by modifying the frit composition. The ability to delay the Initiation of Coupled Operations for both the 200 and 250 canister/year production rates is being evaluated along with the salt processing options. The results of this evaluation will be incorporated in the next revision of the HLW System Plan.

\section{$7.0 \quad$ Key Issues and Assumptions}

Key issues affecting the HLW system are described below. Note that the number of issues has increased since the last revision of the System Plan. Resolution of each of these issues will have a significant impact on the HLW System for years to come. Each issue has an assumed outcome. Assumptions are therefore listed for each key issue. Potential contingency actions are described, should the assumptions prove to be incorrect.

\section{1 "Accelerating Cleanup Plan: Paths to Closure" Plan and Schedule}

Issue: $\quad$ The 11/97 revision of the "Accelerating Cleanup: Focus on 2006" (ACP) document included a High Level Waste Program in which canister production proceeded at a rate of 200 cans per year for several years, peaked at 250 cans per year for several years, and then dropped back down to 200 cans per year for the remainder of the program. That scenario is bounded by the more aggressive 250 canister per year case and the less aggressive 200 canister per year case presented in this System Plan.

Background: $\quad$ Given recent funding expectations, this System Plan presents two possible HLW Production scenarios which bound the one presented in the 11/97 ACP. The 250 Can Case assumes that DWPF will produce 250 canisters per year from FY98-FY18, which accelerates the HLW program end date by two years relative to the $11 / 97 \mathrm{ACP}$. The $200 \mathrm{Can}$ Case assumes that DWPF will produce 200 canisters per year from FY98-FY22, which delays the HLW program end date by three years relative to the 11/97 ACP.

Assumptions: $\quad$ The 250 Can Case assumes that funding and resources are available to accelerate all upstream and downstream processes necessary to support a DWPF production rate of 250 canisters per year. These upstream processes include accelerated waste removal and sludge batch preparation, and accelerated salt processing (needed to remove concentrated supernate and salt from evaporator drop tanks so that evaporators can process DWPF recycle and ESP sludge wash water at increased rates). In addition, downstream processes like the Saltstone Facility will have to operate at faster rates and construct and operate subsequent Saltstone Vaults on an accelerated schedule to dispose of low level salt solutions produced by the upstream salt processing facilities. The schedule for constructing and operating DWPF Glass Waste Storage Building \#2 must also be accelerated by two years, since GWSB \#1 will be filled two years earlier.

The 200 Can Case assumes that funding and resources are limited to a production rate of 200 canisters per year. This extends the HLW program by three years relative to the $11 / 97 \mathrm{ACP}$, and increases life cycle costs considerably.

Contingency: In the interest of decreasing environmental risk by removing liquid high level waste from temporary storage in underground tanks, and minimizing life cycle costs, the HLW System will operate as fast as available funding and resources will allow. 


\section{$7.2 \quad$ Age of the HLW Facilities}

Issue: $\quad$ The materiel condition of many HLW facilities constructed from the early 1950 's to the late 1970's is deteriorating.

Background: $\quad$ The following are examples: The transfer line encasement in F-Area has failed in one place and is leaking in several others. Groundwater intrusion into Tank 19 has been observed. Routine repairs to service systems in the $F$ and $H$ Area Tank Farms have escalated into weeks of unplanned downtime due to the poor condition of the service piping and obsolete instrumentation. In many cases, waste cannot be transferred out of tanks unless temporary services are installed or emergency measures are taken. Aging facilities cause excessive unplanned downtime, addition of unplanned scope to existing projects or the need for new Line Item projects to ensure that the Tank Farm infrastructure will be able to support the HLW Program. It should be noted that the Tank Farm can't be "shut down" as it contains approximately 34 million gallons of highly radioactive waste, much of which is in a mobile form.

Assumptions: $\quad$ The H-Area encasement will not fail and the H-Area Type IV Tanks will not leak or fail. Sufficient funding will be allocated for maintenance of the Tank Farms, and planned Line Item projects will remain on schedule to help refurbish and preserve the Tank Farm infrastructure. These projects include:

$\begin{array}{ll}\text { Tank Farm Services Upgrades (HTF West Hill) } & \text { FY96-FY98 } \\ \text { Tank Farm Storm Water Upgrades } & \text { FY98-FY00 } \\ \text { Tank Farm Support Services (FTF) } & \text { FY99-FY02 }\end{array}$

Contingency: Remove sludge from old-style tanks earlier by consolidating it in new-style tanks prior to feeding it to DWPF. Accept a slowdown of the HLW Program and increased life cycle costs to reallocate funding to the Tank Farm infrastructure. Accept increased environmental risks as tank systems age. Obtain additional funding.

\subsection{Age of the HLW Tanks}

Issue: $\quad$ SRS's 51 underground HLW storage tanks are intended for interim liquid waste storage only. The oldest of these tanks have already been in service for more than 40 years. Eleven of these tanks have a leakage history. Continued storage of liquid waste in these tanks poses a potential threat to the environment.

Background: $\quad$ The first SRS HLW tanks were put into service in the early 1950's. Twentytwo of the 51 tanks are considered "old-style" tanks and do not meet current requirements for secondary containment and leak detection. DOE has enforceable commitments to SCDHEC and the EPA to close these "old-style" tanks (see Appendix E.1). Several of the tanks are partially submerged in the water table. Approximately 34 million gallons of high level waste is stored in the Tanks Farms, much of it in a mobile form.

Assumptions: Successful waste chemistry controls, temperature controls, and construction stress-relief methods will prevent new leak sites. Rigorous tank inspections will monitor known leak sites and detect any new leak sites, if they occur, so that appropriate compensatory actions can be taken. Resources will be available to continue to remove liquid waste from underground tanks, thereby significantly reducing the environmental threat posed by storage of liquid high level waste in underground tanks

Contingency: Maintain emergency storage capacity in the Tank Farms to accommodate transfer of waste from a leaking tank, if a leak occurs. Remove sludge from 
old-style tanks earlier by consolidating it in new-style tanks prior to feeding it to DWPF. Accept increased environmental risks as tank systems age. Obtain additional funding.

\subsection{Tank Farm Waste Storage Space}

Issue: Influent Canyon wastes, delays in salt processing, and extended evaporator outages are consuming the Tank Farms' available waste storage space. Insufficient waste storage space could impact the Tank Farms' ability to support operations in DWPF and the Canyons or lead to adding concentrated waste to old-style tanks that have been emptied.

Background: Planned operations in ITP have been suspended pending a Systems Engineering Evaluation of salt processing alternatives. This evaluation is expected to be complete in October-November 1998, at which time a recommendation for possible process changes and a schedule for resumption of salt processing will be available. If significant process changes are warranted, or if insufficient funding is available, salt processing may be delayed until $\sim$ FYO2 or beyond.

Both the $2 \mathrm{H}$ and $2 \mathrm{~F}$ Evaporators have been shut down for extended unplanned outages, which necessarily impact the evaporators' ability to meet space gain goals. The $2 \mathrm{H}$ Evaporator was down for seven consecutive weeks from MayJuly 1997 to resolve an emergent PISA concern related to the source term in the evaporator vessel, and to implement TSR requirements. In August, $2 \mathrm{H}$ was shut down again for 6 weeks when the GDL plugged with an unexpectedly hard material, which had to be removed by a high pressure water jet. In order to support ongoing DWPF operations during periods when the $2 \mathrm{H}$ Evaporator is not available, DWPF recycle was stored in Tank 22 . The $2 \mathrm{~F}$ Evaporator was also shut down for five weeks from May-July 1997 due to the PISA concern, and was allowed to resume limited operations based on laboratory analysis of feed already available in the $2 \mathrm{~F}$ system. As a result of these lengthy outages, the $2 \mathrm{H}$ and $2 \mathrm{~F}$ Evaporators narrowly achieved their FY97 space gain goals of $1,600,000$ gallons and 900,000 gallons, respectively. The $2 \mathrm{~F}$ Evaporator is currently in a 16-week outage to implement TSRs, and is not expected to resume operations until May 1998.

At the time of this Plan, F-Tank Farm has $\sim 664,000$ gallons of space available, and $\mathrm{H}$-Tank Farm has $\sim 656,000$ gallons of space available.

Assumptions: $\quad$ The Canyon's waste stream volumes and the DWPF recycle volumes will be less than or equal to the forecast. The $2 \mathrm{H}$ and $2 \mathrm{~F}$ Evaporators will operate as planned and achieve their space gain goals for FY98. The RHLWE will start up as planned in June 1999. DWPF recycle will be concentrated to 8 molar hydroxide, which will minimize formation of salt solids in Tank 38. The backlog of dilute supernate currently stored in H-Tank Farm Type III tanks can be successfully retrieved and evaporated as a means to recover space in the Tank Farms.

Contingency: HLW system attainment could be decreased. Planned Canyon programs could be slowed down until the Tank Farm is in a better position to support them. Salt processing may resume earlier than the assumed FYO2. Concentrated supernate could be added to old-style tanks. 


\subsection{Transferring Waste Into Old-Stvle Tanks}

Issue: $\quad$ If salt processing is delayed until FY02 and the waste generating facilities perform as planned, then the Tank Farm waste inventory will exceed the storage capacity in new-style tanks by FY01. The plan is to add concentrated supernate back to Tanks 4-8 starting in FY01.

Background: $\quad$ SRS has established an expectation with stakeholders that once waste was removed from old-style tanks, those tanks would be retired and not reused. However, in order to continue to support Canyon and DWPF operations while salt processing is down, some old-style tanks will be re-used for waste storage.

All 24 of the old-style tanks were evaluated, and most were eliminated from consideration. Tanks 1, 9-16 and 19 have a leakage history. Tanks 2 and 3 lack a viable inlet transfer route. Tank 17 is closed. Tank 18 is the only route by which waste in Tank 19 can be removed. Tank 20 is closed. Tanks 21-24 are still in active service. However, detailed reviews of regulatory documents indicate that Tanks 4-8 could be used. The F/H Area High-Level Waste Tank Farm Partial Permit to Operate, Special Condition \#11, states that:

"Based on a review of the Tank Assessment Report ... the Type I tanks identified as tanks 2-8 are approvable as equivalent devices for secondary containment. The Type I tanks, however, should only be used for waste receipt when there is no suitably available volume in an approved Type III tank."

Some Type III tank space would be maintained, including the $1,271 \mathrm{Kgal}$ emergency space in each Tank Farm as required by the SAR, and the minimum $200 \mathrm{Kgal}$ needed in each evaporator system to efficiently operate the $2 \mathrm{~F}, 2 \mathrm{H}$ and RHLWE evaporators. Given the latest Canyon waste and DWPF recycle forecasts, all remaining Type III tank space will be consumed by FY01. The need to store concentrated waste in Tanks 4-8 has been discussed with SCDHEC, and is included in the Approved FFA Waste Removal Plan and Schedule.

Assumptions: The existing backlog of dilute supernate will be evaporated to the extent possible during FY98-00. Tanks 4-8 will not fail. Concerns about adding liquid to dry sludge in Tanks 5 and 8 can be resolved. Funding and resources will be available to make necessary upgrades in these tanks, such as installing modified leak detection systems and seal plates in valve boxes, refurbishing ventilation systems, repairing or upgrading pumps and annulus jets, upgrading services, installing waste inlet pipes and valves to prevent inadvertent transfers, etc. Both the 250 canister per year case and the 200 canister per year case assume that some concentrated supernate can be stored in old-style tanks.

Contingency: $\quad$ Canyon and DWPF operations could be slowed or stopped commensurate with Tank Farm waste storage capacity. Low activity waste $(<5 \mathrm{Ci} / \mathrm{gal})$ could be added to Tanks 21-24. Salt processing may resume before FYO2 as assumed.

\subsection{Salt Processing Flowsheet and Resumption of Operations}

Issue:

The design and construction of ITP modifications was suspended January 23, 1998. The future of salt pretreatment in terms of the process to be used, cost and schedule, is uncertain. Near term production plans and long term Life Cycle Cost impacts are therefore uncertain.

Background:
ITP completed concentration of Batch \#1, but benzene generation rates greatly exceeded expectations, and cesium decontamination factors decreased with time. The DNFSB issued Recommendation 96-1, which 
recommended against further processing until benzene generation, retention and release mechanisms were adequately understood to ensure that measures to prevent and/or mitigate deflagration were adequate. SRTC initiated a series of experiments to improve the understanding of benzene chemistry. These experiments led WSRC to the conclusion that fuel control in Tanks 48 and 49 could not be credited as a "defense-in-depth" safety feature. In addition, laboratory tests indicated that cesium tetraphenylborate solids may not stay in solution as long as expected; this would affect the efficiency of the process and ITP's capability to support production objectives. WSRC recommended to DOE that further work on ITP be suspended until a Systems Engineering Evaluation was completed.

Assumptions: $\quad$ Since this revision of the System Plan does not have the benefit of a recommended path forward from the Salt Processing Systems Engineering team, the only avenue for modeling purposes was to assume an ITP-like process. Therefore, salt processing was assumed to resume operations starting in FY02. Also, any selected salt process is assumed to process an equivalent quantity of waste as ITP. Therefore, production is assumed to ascend from the equivalent of three 800,000 gallon ITP batches in FY02 to nine 800,000 gallon ITP batches per year starting FY05.

Contingency: There are several contingency actions that could be implemented if salt processing does not start up by FYO2 or if it cannot complete the equivalent of nine 800,000 gallon ITP batches per year:

- Waste could be placed in old-style Tanks 4-8

- the Tank Farms could operate with only one emergency spare tank

- Salt could be formed Tanks 48 and/or 49

- F-Canyon, H-Canyon and/or DWPF processing could be slowed down or halted

- Salt loading level in DWPF canisters could be increased based on the current Waste Acceptance Criteria, and/or by modifying the frit composition

\subsection{TSR Implementation: Scope and Schedule}

Issue: $\quad$ Bringing the F-and H-Area Tank Farms into compliance with DOE Order 5480.22 will require significant manpower resources, and will require capital upgrades to facilities. Implementation of a revised Authorization Basis (AB) program has begun. As administrative control programs are defined, further procedure revisions and equipment upgrades may be required. Equipment functional classification and backfit analyses could result in TSR changes and equipment upgrades. Implementation of TSRs is also expected to cause increases in some routine operations and maintenance costs.

Background: In the past, the Tank Farms' Authorization Basis relied heavily on administrative programs. The new methodology requires significantly more safety related systems and programs to provide adequate protection. Achieving compliance with the new $A B$ documents will require implementing a comprehensive program addressing Limiting Conditions of Operation (LCOS), administrative controls incorporating Process Controls of Operation (PCOs), surveillance requirements, mode change check lists, integrated operating procedures, training and compliance verification. $A$ Basis for Interim Operations $(B / O)$ is in place as one of the Tank Farms' $A B$ documents to specify compensatory measures until the final TSR revisions are completed.

Dedicated, interdisciplinary teams representing Engineering, Operations, Procedures, Maintenance and Training are working to develop and implement 
Technical Safety Requirements (TSRs) and a Basis for Interim Operations $(\mathrm{BIO})$. Implementation is planned in several phases.

Phase $I$ is in progress. In Phase I, training, procedures and surveillances were upgraded and implemented. Authorization Basis $(A B)$ related equipment (e.g., transfer related conductivity probes and the $2 \mathrm{~F}$ and $2 \mathrm{H}$ Evaporator steam control valves) were upgraded from a functional classification of GS/PS to SS/SC. Phase I was completed in H-Tank Farm on March 31, 1998. Phase I will be complete in F-Tank Farm by May 31, 1998.

Phase $I I$ is in progress. In Phase II, additional training, procedures and surveiliances will be upgraded and implemented. Open Issues will be resolved and the TSRs and BIO will be revised accordingly. Upon approval of the TSR and $\mathrm{BIO}$, an implementation schedule will be generated to determine the resources required to implement the requirements as approved. TSRs will be implemented in H-Tank Farm first, with F-Tank Farm to follow, incorporating any Lessons Learned from the $\mathrm{H}$-Tank Farm implementation.

The functional classification (i.e., Safety Class or Safety Significant, SC/SS) of the components in each system will be defined. Equipment backfit analyses and commercial grade dedication evaluations will be conducted to determine if capital upgrades may be required. The backfit analysis will be completed by June 30,1998 and the functional classification process will be completed by September 30, 1998.

Cost/benefit analyses will be performed to evaluate the cost of the equipment upgrades versus risk of no upgrade. Exemptions will be requested as deemed necessary by WSRC.

TSR implementation for F\&H Tank Farms and ITP/ESP is ongoing. However, at the time of this System Plan, a resource-leveled schedule is being prepared to determine a revised implementation date as well as any additional resources and/or funding.

Phase III will implement the next revision of TSRs and resulting upgrades, as required by the Functional Classification evaluations, which may include control room alarms, field modifications and compensatory administrative control measures. Additional training, procedures and surveillances may be upgraded and implemented to support the modifications.

The TSR and BIO will be revised as necessary to implement deferred items as agreed to with DOE. Implementing any deferred items may require additional training, procedures and surveillances to be upgraded and implemented.

At completion of Phase III, the Safety Analysis Report (SAR) and TSR will be revised. Upon approval of these documents, additional training, procedures and surveillances may be required. Full compliance with the requirements of 5480.22 and 5480.23 will be achieved at this point.

Assumptions:

Adequate manpower and funding resources will be applied to support the program. Some exemptions will be requested and granted based on the outcome of the Phase II resource-leveled schedule.

Contingency: If resources are not available and exemptions are not approved, operations will continue under the revised BIO until the TSR program can be fully implemented. HLW system attainment could be slowed to make resources available to support the TSR program. 


\section{$7.8 \quad$ TSR Implementation: Facility Impacts}
Issue:
Significant changes will occur in most daily Tank Farm activities as a result of TSR implementation. The additional requirements mandated under TSRs are expected to increase routine operations and maintenance costs. Such increases in resource needs are difficult to quantify at this point, so additional resources have not been forecast.

Background:

TSR Implementation will provide an improved safety basis for the Tank Farms and ITP/ESP operations. However, additional resources must be applied to comply with TSR requirements, due to more stringent controls and surveillances. The following are examples:

a) LCO 3.2.1 and 3.2.2, Waste Tank Flammable Vapor Control for Rapid and Slow Generation Tanks (respectively): TSR implementation will include new requirements for determining whether the Waste Tanks contain flammable vapor. Under TSRs, Operations will sample the vapor space of each Rapid Generation Tank once per shift, and each Slow Generation Tank twice per week, regardless of whether the tank's ventilation system is operable. This method increases safety by standardizing monitoring frequencies for all tanks, and ensuring that flammability will not exceed $20 \%$ of the CLFL in any tank. However, daily sampling of all tanks is additional work scope for Operations. As an example, at the time of this System Plan, the Tank Farms have four Rapid Generation Tanks and 43 Slow Generation Tanks. Without TSRs, if these tanks lose ventilation or hydrogen monitors, they may require up to 30 vapor space samples in the course of a week. With TSRs, under the same conditions, the same tanks will require almost 150 vapor space samples in a week.

b) LCO 3.3.1, Transfer Path Leak Detection: TSRs categorize all Tank Farm transfers as "liquid transfers," including sump rainwater transfers, for which certain minimum requirements apply. These minimum requirements include siphon evaluations, identification of intended and unintended transfer routes, erecting barricades and installing area radiation monitors at any excavation sites along those routes, and other requirements. In addition to those requirements, transfers of liquid high level waste are subject to requirements related to Operations manning, transfer monitoring, equipment functionality checks, vehicle barriers, and others. These requirements improve safety by ensuring that if a leak or inadvertent transfer occurs, it will be promptly identified so that appropriate response actions can be initiated. However, more facility resources will be needed than before to complete even routine sump rainwater transfers. (Approximately $\mathbf{3 0 0}$ sump transfers are made each year.)

c) LCO 3.2.6, 242-F/H Evaporator Interlocks: TSRs will require that the two tube bundle steam isolation valves on each evaporator will close within 30 seconds at full steam flow. This requirement improves safety by guarding against over-pressurization of the tube bundle and evaporator vessel. However, this surveilance will be required every 3 months, will take a minimum of 3 operators approximately one day to execute, and must be done while the evaporator is shut down. This is a new requirement.

TSRs will also require loop verification every six months for each evaporator vessel's high and high-high pressure interlocks, and for the condenser vent high and high-high temperature interlocks. This requirement improves safety by ensuring that accurate data is transferred from the evaporator system to the control room, so that Operations personnel can operate the evaporators within approved parameters, and respond appropriately to process upsets. However, the loop checks will require 3 mechanics, 1 RadCon inspector, 2 QA 
inspectors and an Operations interface to execute; will take several days to complete; and can only be executed when the evaporator is shutdown. This may extend the duration of planned outages. Previously, the loop verifications were only required once per year.

d) Functional classification efforts to date have resulted in upgrading 291 conductivity probes, 22 hydrogen monitors, and 18 evaporator instruments, all from GS/PS to SS/SC. Additional upgrades of valves, jumpers and transfer lines are anticipated as a result of backfit analysis. This improves safety by ensuring that key components will continue to function during the design-basis accidents defined by the SAR. However, the SS/SC designation imposes stringent requirements on all aspects of the equipment, from manufacturing and acceptance testing through installation, operation and maintenance. These requirements impact many facility organizations, including Procurement, QA, Engineering, Work Control, Procedures and Training, so operating costs are expected to increase.

Assumptions: $\quad$ Cost efficiencies can be identified and implemented such that existing resources will be sufficient to comply with TSR requirements without adversely impacting cost or schedule.

Contingency: HLW System attainment could be slowed commensurate with available resources.

\section{$7.9 \quad$ KeV HLW Processing Parameters Uncertainty}

Issue: $\quad$ Subtle changes in a few key waste characteristics could dramatically impact HLW processes and the overall length of the HLW Program.

Background: This Plan assumes that all of the aluminum in the sludge is in the form gibbsite, $\mathrm{Al}(\mathrm{OH})_{3}$, which is soluble, and can be removed by the aluminum dissolution process at ESP. However, some could be in the form of boehmite, $\mathrm{AlO}(\mathrm{OH})$, or aluminum silicates, which do not dissolve completely, and therefore would not be removed in ESP. This could impact processing in DWPF. This Plan assumes that 2 wt\% insoluble solids are entrained in saltcake. If the actual amount is higher, more canisters of glass will be produced. This Plan assumes that the accepted total potassium inventory in the Tank Farms is complete. An increase in the amount of potassium will drive increases in total precipitate production.

Assumptions: Waste sample analyses are being refined to obtain additional needed information without increasing the number of samples. Sample results will confirm the waste composition and characteristics described above. Operating experience in facilities throughout the High Level Waste System will improve our understanding of the relationships among waste composition, waste characteristics and waste processing. Facility processes will be adjusted as necessary. Blending of feed to Salt Disposition and ESP will compensate for any transient (high or low) conditions in individual waste tanks.

Contingency: Additional waste tank samples could be retrieved and analyzed. Modifications to some facilities could be required. The total number of canisters to be produced may increase. The overall High Level Waste program could be lengthened. 
Background:

Assumptions:

(Tanks $4,7,12$, and 14) "ready to feed" to DWPF are behind schedule, and must be accelerated to maintain continuous sludge feed to DWPF.

The baseline plan for the operation of the HLW System was based on the following:

- Production of 60 canisters in FY96

- Production of 150 canisters in FY97

- Production of 200 canisters per year from FY98 to FY04

- 3,705 pounds glass per canister

- waste loading of $28 \mathrm{wt} \%$ sludge oxides in glass

Actual production exceeded the plan by 4 canisters in FY96 and 19 canisters in FY97. The FY98 year-to-date production rate is 250 canisters/year. About 4,000 pounds of glass are being placed in each canister and waste loading has been increased slightly above $28 \mathrm{wt} \%$. These three factors, when combined with the desire to sustain this performance, result in the schedule imbalance.

In order to maintain continuous sludge feed to DWPF, the Sludge Batch \#2 "ready to feed date" must be accelerated by 10.5 months, to $5 / 15 / 00$. The Sludge Batch \#3 "ready to feed date" must be accelerated by 15 months, to 4/02. The Sludge Batch \#4 "ready to feed date" must be accelerated by 21 months, to $8 / 04$. WSRC is actively working to improve these schedules.

The outage to transition from Sludge Batch \#1A to \#1B will be two weeks or less. All of the sludge in Tank 42 except the 75,000 gallon heel will be transferred to Tank 51. Sludge Batch \#1B will perform as modeled. There will be no melter failure in this time frame. There will be no specific Y2K outage; Y2K modifications will be completed during other planned outages. WSRC will be able to improve subsequent Sludge Batch schedules to sustain a production rate of 250 canisters/year.

Contingency: $\quad$ Any unplanned outage will reduce the schedule imbalance. A very successful Tank 42 to Tank 51 sludge transfer where significantly less than 75,000 gallons of sludge remain in Tank 42 will reduce the schedule imbalance. The DWPF production rate could be reduced. An extended outage in FY99 or FYOO could be planned.

\subsection{Year 2000 Compliance}

Issue: $\quad$ Many of the HLWMD's computer systems are not "Year 2000 Compliant," and may not work properly, or may not work at all, after January 1, 2000, unless repairs are made in advance. Operations of all HLWMD processes could be impacted.

Background:

The software in many microprocessors assumes that in any four digit year, the first two digits are always 1 and 9 , and only the last two digits are used to indicate a particular year. That is, many microprocessors interpret " 99 " as "1999." At the turn of the century, the last two digits of the new year will be "00," but many microprocessors will interpret that as the year 1900. This will cause disruptions in programs using timing or date-related functions.

Each manufacturer's code is different, so solutions must be developed for each different microprocessor, application or system. No one solution will work for everything. Fixes may include modifications to hardware as well as software. Existing equipment and software will be utilized to the extent practical, but some procurements will be required. 
Affected HLWMD systems include: process control systems (i.e., the Distributed Control Systems in F-Tank Farm, DWPF, the RHLWE, H-DB8 and Waste Removal); programmable logic controllers; data acquisition systems; engineering and scientific systems; process support systems; databases or data intensive systems (DWPF's Laboratory Information Management Systems \{LIMS\}, DWPF's Process Information Management Systems [PIMS\}, and the HLWMD Work Management System \{WMS\}); and others. In addition, some HLWMD systems were supposed to be fixed under the now-defunct SAP program, and now will be addressed by HLWMD resources. These include QA Tracker, BCP Tracker, PDMS, Image Expander, Tech Base and others. Some systems will not be cost effective to fix, and so will be abandoned.

A dedicated HLWMD Y2K Team has completed its inventory of affected HLW systems, and has planned a path forward. The scope of work required to fix each major system is being defined, and schedules are developed. Outage schedules will be carefully integrated with other facility work scope and priorities to minimize production impacts. All affected mission-essential HLW systems are expected to by Y2K compliant by October 31, 1999 . Other affected systems which have medium- or low-priority will be addressed after mission-essential systems have been fixed. Some Y2K scope for mediumand low-priority systems may extend into FY00.

Assumptions: Highest priority will be given to fixing those systems related to human health, safety and the environment. Vendors of affected hardware and software will provide some support. Additional resources can be identified and allocated to implement solutions. Production outages can be scheduled so as to minimize the impact on HLW system attainment.

Contingency: $\quad$ All HLW processing, including DWPF operations and receipt of Canyon wastes, could be slowed or halted until appropriate repairs can be made.

\subsection{Integrated Production Plan}

\subsection{Overview}

The following integrated production plan supports production of 250 canisters per year, starting in FY98 and continuing through FY17. However, note that successful implementation of this production plan is contingent upon: availability of funding as shown in Appendix C.1; successful acceleration of waste removal projects in the Tank Farms; acceleration of sludge batch preparation in ESP; increased salt processing rates at ITP/LW and Saltstone; and acceleration of GWSB\#2 project. All of the Approved FFA Waste Removal Plan and Schedule commitments will be met. The funding required to support the HLW program at 250 cans per year is shown in Appendix C.1.

This section describes the effect of each influent and effluent stream in the Tank Farms, and its impact on Tank Farm operations, as illustrated in Appendix G.1. Sections $\mathbf{8 . 2}$ through $\mathbf{8 . 1 0}$ describe the production requirements for each HLW facility to support this Plan.

\section{HLW System Material Balance}

The Tank Farm Material Balance shown in Appendix G.1 is the key tool used to develop this Plan. The balance between influents to the Tank Farm and effluents to DWPF, Saltstone and the Effluent Treatment Facility is critical during the next ten years due to the current low working inventory of tank space in the Tank Farms. The lack of tank space impacts the ability to receive influents from Separations and DWPF and to store salt concentrate from the evaporators. A review of the forecasted influents and effluents and their impact on the HLW System is provided below.

Tank Space Available: Influents and effluents are listed only as they impact the Type III Tanks that are used to store and evaporate HLW, herein referred to as the "Available" tank space. The Available Tank Space is calculated as follows. 
The old-style tanks (Tanks 1-3 and 9-24) are excluded because they do not meet current requirements for secondary containment and leak detection, and so the Tank Farm Industrial Wastewater Operating Permit does not generally allow waste to be added to those tanks. Tanks 4-8 may be used to store concentrated waste in the future, but field modifications will be required before those tanks can be used. Therefore, they are not included in the "available space" at this time.

Salt Disposition Tanks 48,49 and 50 are excluded primarily because unplanned additions of large waste volumes would alter the waste composition, possibly violating strict process chemistry controls, and may impact the ability to efficiently implement a salt processing alternative.

ESP Tank 51 is excluded from the Available Tank Space calculation because unplanned additions of waste would alter the washed sludge composition, interrupting feed to DWPF while the waste is requalified. (Note that in FY99, when Tank 40 begins processing sludge for Sludge Batch \#2, Tank 40 will also be excluded from the Available Tank Space calculation.)

Each Tank Farm is required to maintain 1,271,000 gallons of space in Type III/IIIA Tanks, to accommodate emergency storage of waste in the unlikely event of a tank leak.

For planning purposes, the maximum capacity of all the remaining Type III and Type IIIA tanks is assumed to be $1,270,620$ gallons, which is 35,100 gallons less than the Technical Standard limit of $1,305,720$ gallons. The only exceptions to this are the $2 \mathrm{~F}$ and $2 \mathrm{H}$ Evaporator feed tanks, Tanks 26 and 43 , in which the Operating Limit is $1,228,500$ gallons, due to the elevation of the feed pump motor.

The "Available Tank Space" column in Appendix G.1 is the working inventory of tank space available to support routine Tank Farm activities, such as inter-tank transfers and evaporator decants. The Available Tank Space represents space available in addition to the Type III Tanks identified above, and in addition to the 2,542,000 gallons that are always reserved for emergency spare space. At the time of this Plan, the F- and H-Tank Farms have a combined $1,319,353$ gallons of working space available.

In order to maintain sufficient space available in the Tank Farms to meet minimum SAR requirements and continue to support planned waste transfers from the Canyons and DWPF, the Tank Farms have begun evaporating backlogged, dilute supernate from Type III tanks. This is expected to recover approximately $5,000,000 \mathrm{gal}$ of space over the period FY98-FY00.

Influents - F-Canyon Low Heat Waste (LHW) and High Heat Waste (HHW): Reprocessing of Taiwan Research Reactor (TRR) fuel is still in progress and is expected to complete in June 1998. Approximately 16,000 gallons of High Heat Waste and 57,000 gallons of Low Heat Waste are expected from TRR processing. SRS Plutonium Scrap Processing is scheduled from May 1998 to September 1998, and is expected to generate $\sim 12,000$ gallons of Low Heat Waste. The Record of Decision for Rocky Flats Plutonium Scrap has not yet been finalized, but if that material is brought to SRS, reprocessing could occur in FY99 and FY00. A Process Vessel Vent (PVV) flush, tentatively scheduled for September 1998, will generate an additional $-12,000$ gallons of low heat waste. For planning purposes, F-Canyon de-inventory flushes are assumed to occur from April-August 2000, generating $-20,000$ gallons of low heat waste per month and $-2,000$ gallons of high heat waste per month. Starting in September 2000 , shutdown flows of $\sim 10,000$ gallons per month low heat waste and zero high heat waste are forecast.

Influents - H-Canyon Low Heat Waste (LHW) and High Heat Waste (HHW): H-Canyon began dissolving K14 charges and operating the head-end of the process in July 1997. At the time of this System Plan, WSRC is waiting for DOE approval to start first cycle. Processing of the K14 charges is expected to produce $\sim 20,000$ gallons of Low Heat Waste per month through July 1998. A 4,000 gallon transfer containing Pu-242 was planned, but has been deferred in light of a recent DOE decision to recover the Pu-242. A Special Waste Compliance Plan is being developed for planned transfers containing Pu-238. The Pu-238 material will be diluted to $\sim 40,000$ gallons because of source term limits in the Tank Farms. A Warm Canyon PVV filter flush previously scheduled in March 1998 is on hold pending discussions with DOE. Anion exchange recovery of Neptunium in HB- 
Line is being planned, but is not currently scheduled. Processing of Mark 16 and Mark 22 charges will begin in July 1998 and continue through May 2001, generating $\sim 10,000$ gallons of low heat waste per month, and $\sim 14,000$ gallons of high heat waste per month. Beginning in June 2001, the only forecast activity is HB Line Plutonium scrap processing, which will generate just $\sim 3,000$ gallons of low heat waste per month, and zero high heat waste.

Influents - DWPF Recycle: DWPF recycle volume will vary over the life of the facility. The volume of recycle generated reflects sludge-only canisters versus combined sludge and precipitate canisters, planned canister production rates, and the age of the facility. (As the facility ages, increased maintenance needs for contaminated equipment will increase, thereby increasing the amount of spent decontamination water generated.) Over the life of the program, the recycle volume will range from $\sim 2,278,000$ gallons per year to $\sim 3,114,000$ gallons per year. The recycle algorithm has been updated to reflect recent facility operating experience, and is explained in Section 8.6.

Influents - Tank Wash Water: The waste tank interiors of all tanks to be removed from service are water washed as part of the waste removal program. The annulus of each tank with a leakage history is also water washed. The volume of the tank interior wash is planned to be 140,000 gallons, which is a level of about 40 inches in most tanks. The annulus wash is assumed to be two 25,000 gallon washes, which is a level of about 24 inches in the annulus for each wash. This Plan assumes that all tanks are water washed.

Influents - ESP: The ESP wash water volumes are based on CPES and ProdMod modeling for each of the remaining sludge batches. The wash water for each batch is generated during the $\sim 12$ month period immediately before the batch is fed to the DWPF. No distinction is made between the water used to slurry and transport the sludge to the ESP tanks, aluminum dissolution waste, and sludge wash water. All of the wash water will be evaporated. For more details on ESP, refer to Section 8.5.1.

Other Influents: Influents from the 100-Areas were listed in previous revisions of this Plan but are now planned to be zero. There are no plans to support the Reactor Basin water quality programs using HLW tanks. The Receiving Basin for Offsite Fuel (RBOF) impact on the Working Inventory is projected to be zero because the RBOF waste will be stored in Tank 23, and when Tank 23 fills, that waste will be used to dissolve salt.

Effluents - Evaporators: The $2 F, 2 \mathrm{H}$, and RHLWE reduce the volume of dilute, influent waste streams. In order to maintain available space in the Tank Farms during the extended Salt Processing evaluation outage, the evaporators have also begun to evaporate dilute supernate from Type III tanks. This is expected to recover approximately 5,000,000 gal of space over the period FY98-FY00. Reference to "evaporator space gain" is a misnomer, because evaporator operations can only minimize the effect of waste additions as saltcake and caustic liquor accumulate. The only true source of Tank Farm space gain is to operate a Salt Processing facility, thereby processing the salt and supernate into an acceptable solid waste form (glass or grout). For more details on evaporator operations, refer to the "Evaporator Salt Inventory" section below, and Sections 8.2.2 and 8.3.2.

Effluents - Salt Processing (In-Tank Precipitation or other): Space gain occurs when concentrated supernate, unconcentrated supernate, or dissolved saltcake is fed to a Salt Processing facility. Previous revisions of the System Plan waited to recognize space gain from dissolved salt until the entire tank had been emptied and returned to salt service. However, this Plan credits recovered space immediately, since that space could be made available to store 1) concentrated supernate from an active evaporator drop tank, or 2) any liquid waste, in the unlikely event of a tank leak. Although the salt processing flowsheet is currently under re-evaluation, for planning purposes, this Plan assumes that space gain can be achieved using the existing ITP flowsheet and ITP Production Plan as shown in Appendix G. For more details on Salt Processing and ITP, refer to Section 8.5.2. 


\section{Evaporator Salt Inventory}

The evaporators volume reduce the various waste streams coming into the Tank Farms. This is crucial to the success of HLW and Site Missions. The evaporators must keep current with waste generated by Canyon operations, DWPF recycle, ESP spent wash water, and HLW tank wash water.

Evaporator space gain is defined as the difference between evaporator feed and evaporator concentrate, corrected for flush water and chemical additions necessary to operate the evaporator system. Space gain is predicted based on evaporation of each waste stream, given its chemical constituents. This is further described in Sections 8.2.2 and 8.3.2.

When the saltcake level reaches 1.0 million gallons in a salt receipt tank, the tank is considered full. (The remaining 0.3 million gallons of space typically contains concentrated supernate.) At that time, another salt receipt tank is required or the evaporator will become salt bound and shut down. Appendix G.1 shows the salt formation in each of the three evaporator systems. Note that the volume of concentrated supernate is not explicitly shown, because this Plan assumes that concentrated supernate can be transferred out of the evaporator systems as needed, and either fed directly to the salt processing facility or stored in another Type III tank. Evaporator operating plans are carefully balanced with salt processing feed plans, so that the evaporators can support the influent waste forecast without becoming salt bound.

\subsection{H Tank Farm}

The H-Tank Farm receives, stores, evaporates, and transfers high level waste.

\subsubsection{H-Tank Farm Space Available}

The H-Tank Farm includes twelve old-style waste storage tanks, eleven new-style tanks, and three evaporator systems. At the time of this Plan, H-Tank Farm has $\sim 656,000$ gallons of space available.

\subsubsection{H-Tank Farm Evaporators}

The 1H Evaporator vessel has a leaking tube bundle. There are no plans to restart this evaporator. Therefore, the condition in the Tank Farm Wastewater Operating Permit to remove the $1 \mathrm{H}$ Evaporator from active service by $1 / 1 / 98$ has been met.

The $1 \mathrm{H}$ system was chemically decontaminated in FY96. The evaporator cell, the interior of the evaporator vessel, the Concentrate Transfer System (CTS) cell, the CTS tank interior and the CTS loop line were cleaned using alternate caustic/acid flushes similar to the method used for the $2 \mathrm{H}$ Evaporator vessel replacement. The $1 \mathrm{H}$ system is currently in lay-up mode.

The 2H Evaporator system includes one feed tank (Tank 43) and two salt receipt tanks (Tanks 38 and 41). Tank 38 is the active tank; Tank 41 is full of salt. The primary role of the $2 \mathrm{H}$ Evaporator in FY98 is to evaporate the 221-H Canyon LHW stream and the DWPF recycle stream, both of which are normally received in Tank 43 and evaporated. After the RHLWE starts up, the DWPF recycle volume will be divided between the RHLWE and $2 \mathrm{H}$.

At the time of this Plan, $\mathrm{H}$-Tank Farm had received $-46,000$ gallons of low heat waste from $\mathrm{H}$ Canyon, and $-1,278,000$ gallons recycle from DWPF (fiscal year to date, FYTD). The $2 H$ Evaporator has achieved $\sim 1,225,000$ gallons space gain, which is $\sim 247,000$ gallons over and above the target space gain of $\sim 977,000$ gallons for this date (FYTD). The $2 \mathrm{H}$ evaporator utility has averaged $82 \%$ per month FYTD, with a high of $98 \%$ in March 1998.

The current forecast for the remainder of FY98 calls for an additional $\sim 85,000$ gallons of $H-L H W$, and $\sim 1,043,000$ gallons of DWPF recycle. The $2 \mathrm{H}$ Evaporator is expected to achieve its FY98 space gain goal of $1,800,000$ gallons.

Video inspections and material balances made during March 1998 indicated that the salt volume in Tank 38 was $\sim 903,000$ gallons, which is approaching the maximum capacity of the tank. The $2 \mathrm{H}$ Evaporator's only other salt receipt tank is Tank 41 , which is already filled. Plans to dissolve the Tank 41 salt were suspended pending resumption of salt processing. Therefore, to extend the useful life of Tank 38, the operation of the $2 \mathrm{H}$ Evaporator was changed to produce a concentrate stream 
with a specific gravity of $1.30-1.45$, vice a previous level of $1.50-1.55$. Approximately $90 \%$ of the waste volume reduction can still be achieved at the lower specific gravity, by concentrating the waste to a sodium molarity just below the point at which saltcake is formed. The concentrated supernate will be periodically transferred to the Tank Farm to enable the evaporator to continue operating. The most recent such decant occurred in March 1998, when $\sim 329,000$ gallons of concentrated supernate were transferred to Tank 40.

Space gain for the $2 \mathrm{H}$ evaporator is driven by the volume and salt content of H-LHW and DWPF recycle streams, and by the specific gravity at which the evaporator is operated. The Appendix G.1 Tank Farm Material Balance uses an algorithm to forecast space gain. Based on historical and laboratory test data, the volume reduction for $\mathrm{H}$-LHW is typically $71 \%$. Space gain factors for all streams are based on historical and laboratory test data where available, process models, and projections of waste stream composition. However, since the evaporator is currently operating at a lower specific gravity, this Plan assumes that the volume reduction for DWPF recycle is $90 \%$. For now, the $2 \mathrm{H}$ space gain algorithm is:

$$
2 H \text { Space Gain }=(H-L H W)^{\star}(0.71)+(\text { DWPF Recycle })^{\star}(0.9)
$$

During the first 15 months of RHLWE operations, the RHLWE will have a significant quantity of backlogged supernate to evaporate in addition to its normal load. In order to balance space gain expectations between the RHLWE and the $2 \mathrm{H}$ evaporator, the DWPF recycle stream will be divided $25 \%$ to $\mathrm{RHLWE}$ and $75 \%$ to $2 \mathrm{H}$. During this period, the $2 \mathrm{H}$ Evaporator space gain algorithm will be:

$$
2 H \text { Space Gain }=(H-L H W)^{\star}(0.71)+(0.75)(\text { DWPF Recycle })^{\star}(0.9)
$$

Once the RHLWE has completed its processing of backlogged wastes, the DWPF recycle stream will be redistributed $50 \%$ to RHLWE and $50 \%$ to $2 \mathrm{H}$. From then on, the $2 \mathrm{H}$ Evaporator space gain algorithm will be:

$$
2 \mathrm{H} \text { Space Gain }=(H-L H W)^{\star}(0.71)+(0.50)(\text { DWPF Recycle })^{\star}(0.9)
$$

Appendix G.3 indicates that the 2H Evaporator is planned to gain about 2,000,000 gallons per year. The ability to do this was demonstrated in FY96. However, few unplanned outages occurred in FY96 to interrupt $2 \mathrm{H}$ operations. By contrast, the $2 \mathrm{H}$ Evaporator system encountered two long, unplanned outages in recent months. On May 7, 1997, the 2H Evaporator was shut down in response to a Potential Inadequacy in Safety Analysis (PISA) regarding the source term in the evaporator vessel. Sample analyses of Tank 38 indicated a higher-than-expected quantity of sludge solids, which could only have come from Tank 43 and through the evaporator. Given this condition, the projected source term in the evaporator was calculated to exceed the SAR limit for offsite dose in the unlikely event of an evaporator explosion. During the subsequent outage, two major modifications took place. The Tank 43 feed pump eductor was raised well above the known height of sludge in Tank 43 , to prevent further entrainment of sludge solids in evaporator feed. Also, a safety class steam cut-off valve was installed to automatically stop steam feed to the tube bundle. The $2 \mathrm{H}$ Evaporator resumed operations on July 4, 1997, and ran well for 15 days.

On July 19, 1997 the $2 \mathrm{H}$ Evaporator was shut down again, this time because the gravity drain line (GDL) was plugged. Standard flushing techniques failed to clear the line. Remote video inspection of the GDL indicated that the plugged material was different than anything previously encountered. The material was sampled and analyzed at SRTC. The analysis showed that the deposit may have been caused by a combination of frit carryover from DWPF and incorrect positioning of the Tank 43 feed line to the $2 \mathrm{H}$ evaporator. When the frit was combined with the aluminum and caustic in Tank 43 , and then exposed to the heat in the evaporator, it may have formed the chemical compound that plated out in the GDL. A vendor with a 10,000 psi pressure wash system had to be brought in to clear the line. The $2 \mathrm{H}$ Evaporator resumed operations on September 2, 1997, and narrowly achieved its FY97 space gain goal of $1,600,000$ gallons.

These two unplanned, extended outages demonstrated the evaporator's critical role in maintaining a balance between Tank Farm influents and effluents. During the outages, DWPF recycle rapidly 
collected in Tank 43. When the 2H evaporator resumed operations on September 2, the HLWMD had come within 7 days of implementing one of several contingency plans. These included reducing the operating capacity of the evaporator system; diverting additional recycle to Tank 40; or restricting recycle influent to the Tank Farms, and thereby curtailing DWPF operations. In light of this, an alternative path for DWPF recycle was established to Tank 22. Although every effort is made to coordinate planned outages between the Tank Farms and DWPF, unplanned outages do occur. At the time of this Plan, the Tank 22 inventory includes $\sim 328,000$ gallons of unevaporated DWPF recycle. Fortunately, the collected DWPF recycle may be useful as Tank 40 sludge wash water, which will be needed in FY99.

To provide even greater flexibility for the H-Area Tank Farm, however, activities are in progress to re-jumper HDB-8 and HDB-5 so that DWPF recycle can be diverted to Tank 21 or Tank 22 for storage during $2 \mathrm{H}$ evaporator system outages. The normal HLW System configuration for these transfers uses the S- to H-Area inter-area line to the Low Point Pump Pit, then to the HDB-8 Complex, through HDB-7, and finally to Tank 43 , which feeds the $2 \mathrm{H}$ Evaporator. The same route can also be used to transfer recycle into Tank 38 when necessary. A route through HDB-8 and HDB5 also exists, which allows the DWPF recycle to be transferred to Tank 22 . At the time of this System Plan, HDB-5 and HDB-8 are being re-jumpered to allow DWPF recycle to be transferred through HDB-8 and HDB-5 to Tank 21 as well. This will provide additional flexibility for the Tank Farms to accept DWPF recycle when Tank 43 is unavailable.

The $2 \mathrm{H}$ Evaporator vessel was replaced in December 1995, and the feed pump was replaced in January 1997. The new vessel has a Hastelloy tube bundle and warming coil that is expected to last for 30 years. Therefore, downtime for pot replacement is not forecast. 2H Evaporator operation is based on a planned utility of $60 \%$ with a space gain as shown in Appendix G.1. Utility averaged $58 \%$ in FY97, with a peak of $93 \%$ in April. The $2 \mathrm{H}$ evaporator is expected to operate continuously until FY19.

The Replacement High Level Waste Evaporator (RHLWE) achieved its milestone for mechanical completion (i.e., construction completion) on November 17, 1997, thirteen days ahead of the AOP milestone. Hot tie-ins to Tank 32, which will be the RHLWE feed tank, are in progress and are expected to be complete in April 1998. Other hot tie-in locations are being prepared, and are expected to be complete by August 1998. Start-up testing is in progress and is expected to complete in April 1999. Operator training began in February 1998 and is expected to complete in November 1998. A Readiness Assessment (RA) is scheduled prior to the start of Radioactive Operations in June 1999.

The RHLWE startup date is linked to the resumption of sludge washing. In the 250 canisters per year case, Batch 2 sludge washing must begin $8 / 15 / 98$. That means RHLWE startup is already 10.5 months behind the optimum startup date. In the 200 canisters per year case, Batch 3 sludge washing must begin 4/19/99, which makes RHLWE startup 2.5 months behind the optimum startup date. There is no contingency in the RHLWE startup schedule to recover either of these schedule disconnects. In addition, at the time of this System Plan, there is some discussion of having an Operation Readiness Review (ORR) instead of the RA. In either the $\mathbf{2 5 0}$ or 200 canisters per year case, an ORR would most likely delay the start of Radioactive Operations by approximately 3 more months, potentially impacting the start of Sludge Batch \#2 washing. Discussions with DOE are ongoing.

The RHLWE is planned to operate at $80 \%$ utility and at a space gain based on the forecasted availability of feed. The space gain values shown in Appendix G.3 are well within the expected capacity of the RHLWE. The design basis is 7,600,000 gallons per year of overheads assuming feed at $33 \mathrm{gpm}$ at $25-35 \%$ dissolved solids.

The RHLWE role will be to evaporate a portion of the ESP wash water; a portion of the tank wash water generated in H-Area; all of the H-Area High Heat Waste Stream, a portion of the DWPF recycle stream, and a significant quantity of backlogged supernate. The RHLWE space gain algorithm is derived as follows. H-Area has about $64 \%$ of all sludge, thus $64 \%$ of the sludge wash water is allocated to the RHLWE. The space gain factor for the ESP wash water is estimated at 
$85 \%$. H-Area has 29 of the 51 tanks, thus $56 \%$ of the tank wash water is allocated to the RHLWE. The space gain factor for tank wash water is estimated at $90 \%$. All fresh Canyon wastes can be evaporated with a space gain factor of $71 \%$. The space gain factor for DWPF recycle evaporated through the RHLWE is expected to be $90 \%$. Specific quantities of backlogged waste, each with space gain factors unique to the source tank, have also been allocated to RHLWE during its first 15 months of operation. In order to balance space gain expectations between the RHLWE and the $2 \mathrm{H}$ evaporator during this 15-month period, the DWPF recycle stream will be divided $25 \%$ to RHLWE and $75 \%$ to $2 \mathrm{H}$. During this period, the RHLWE space gain algorithm will be:

$\begin{aligned} \text { RHLWE Space Gain }= & (0.64)^{\star}(\text { ESP wash water })^{\star}(0.85)+ \\ & (0.56)^{*}(\text { tank wash water })^{*}(0.90)+ \\ & (1.00)^{\star}(\text { H-High Heat Waste })^{\star}(0.71) \\ & (0.25)^{\star}(\text { DWPF recycle })^{\star}(0.90)+ \\ & \text { backlogged supernate }\end{aligned}$

After the first 15 months, planned evaporation of backlogged supernate will be complete. At that time, the RHLWE will begin evaporating $50 \%$ of DWPF recycle, and the algorithm used to forecast RHLWE space gain in gallons per year (after the first 15 months of operation) will be:

$$
\begin{aligned}
\text { RHLWE Space Gain }= & (0.64)^{\star}(\text { ESP wash water })^{\star}(0.85)+ \\
& (0.56)^{*}(\text { tank wash water })^{*}(0.90)+ \\
& (1.00)^{*}(\text { H-High Heat Waste })^{\star}(0.71) \\
& (0.50)^{\star}(\text { DWPF recycle })^{*}(0.90)
\end{aligned}
$$

Backlog supernate feed to the RHLWE in FY99 includes $\sim 700,000$ gallons of dilute waste already present in Tank 30, the RHLWE's initial drop tank. In FY00, backlog feeds will include an additional $\sim 388,000$ gallons of Tank 30 inventory, plus $\sim 400,000$ gallons from Tank 32 , and $\sim 200,000$ gallons from Tank 42 (presently stored in Tank 40).

The RHLWE project scope currently includes installation of gravity drain lines to Tanks 29 and 30 . Gravity drain lines to Tanks 31 and 37 were deleted from the project in light of project TEC concerns. The RHLWE will start up with Tank 32 as its feed tank, and Tank 30 as its drop tank. By the time the waste volume in Tank 30 has reached one million gallons, Tank 29 will be empty and ready for salt receipt service.

\subsubsection{H-Tank Farm Waste Removal Operations}

\section{Salt Removal}

Tank 41 will be the first tank to feed dissolved salt cake to the salt processing facility. Relatively high concentrations of fissile uranium and plutonium anticipated in Tank 41 saltcake prompted WSRC to conduct a Nuclear Criticality Safety Study. The concern was that insoluble fissile materials could concentrate in low spots in the salt formation inside Tank 41. Sampling and analytical studies indicated that initiation of salt dissolution can safely proceed. Completed evaluations indicated that the top 50" of saltcake can be safely dissolved. The criticality safety concern will be managed via sampling to confirm neutron poison content as waste removal proceeds. The increased time requirement to remove salt in this way is incorporated into the schedule. Tank 41 dissolved salt will be fed to the salt processing facility over the period FY02-FY05.

As before, there is a strong need to empty Tank 41 as soon as possible in order to maintain the operation of the $2 \mathrm{H}$ Evaporator. The initial salt removal from Tank 41 will be slow due to the lack of working capacity in the tank and the criticality sampling requirements. As salt is removed, larger and larger salt removal batches can occur. Tank 42 must be available to stage the dissolved salt from Tank 41 to allow insoluble solids to settle prior to transferring to Tank 48.

Tank 29 will be the second tank fed to the Salt Processing facility. The RHLWE will start up dropping salt concentrate to Tank 30 . Tank 30 is expected to fill by FY05. Tank 29 must therefore have all of the salt removed, the cooling coils replaced (if needed) and the tank returned to salt receipt service by FY05. Tank 29 is currently projected to be empty by FY04. Tank 29 is the only 
tank in the RHLWE system outfitted with slurry pumps. Only two pumps will be installed in Tank 29 pending results from alternate salt removal demonstrations. A third pump could be installed later if required.

Tank 38 is currently projected to be the first salt tank to be designed with alternate salt removal technology. The three alternate demonstrations to be conducted in Tanks 25 and 41 will be used to generate the technical basis for the design of Tank 38 . This design is expected to save $\sim \$ 6$ million per salt removal tank in capital costs, and to be applicable to Tanks $1,2,3,9,10,27,30,31,36,37$, 44,45 and 46.

\section{Sludge Removal}

Sludge from Tank 11 will be processed as part of Sludge Batch 4 . Work on Tank 11 is already underway. The current schedule is as follows. In FY99, as-built drawings will be developed, a waste removal design contract will be awarded, and most of the waste removal design work will be completed. In FYOO, the design will be completed, a construction contract will be awarded, and most of the construction will be completed. In FY01, the four slurry pumps will be installed and tested, with sludge removal completed by June. However, this schedule is 12 months too late to support the 250 canister per year case. Efforts are underway to improve this schedule. The existing schedule for Tank 11 waste removal is well ahead of the approved FFA Waste Removal Plan and Schedule date to close Tank 11 by the end of FY10.

Sludge from Tank 12 and Tank 14 will be processed as part of Sludge Batch 5 . in FYOO, design bids will be received, a design contract will be awarded, and design will be completed. In FY01, construction bids will be received, a construction contract will be awarded, and construction will be completed. In FY02, slurry pumps will be installed and tested, and bulk waste removal will begin. Bulk waste removal would be complete by the end of February of FY03. This schedule is still 6 months too late to support the 250 canister per year case. Efforts are underway to improve this schedule. The existing schedule for Tanks 12 and 14 waste removal is well ahead of the approved FFA Waste Removal Plan and Schedule date to close Tanks 12 and 14 by the end of FY11 and FY10, respectively.

Sludge from Tank 13 and Tank 15 will be processed as part of Sludge Batch 6 . Walkdowns and asbuilts are scheduled for the last six months of FYOO. Receipt of design bids, award of the design contract, and completion of design is scheduled for FY01. Receipt of construction bids, award of the construction contract, and completion of construction is scheduled for FYO2 and FY03. Also in FY03, the slurry pumps would be installed and tested. Bulk waste removal is scheduled to be complete by the end of FY04. This schedule supports the 250 canister per year case, and is well in advance of the Approved FFA Waste Removal Plan and Schedule dates to close Tanks 13 and 15 by FY15 and FY13, respectively.

\subsubsection{H-Tank Farm New Facility Planning}

For details on projects currently planned in H-Tank Farm, refer to Appendix D.

\subsection{F-Tank Farm}

The F-Tank Farm receives, stores, evaporates, and transfers high level waste.

\subsubsection{F-Tank Farm Space Available}

The F-Tank Farm includes twelve old-style waste storage tanks, two of which are now closed; ten new-style tanks; and two evaporator systems. At the time of this Plan, F-Tank Farm has $\sim 664,000$ gallons of space available.

\subsubsection{F-Tank Farm Evaporators}

The IF Evaporator was shut down in 1988 because of high maintenance and lack of feed. There are no plans to restart this evaporator system. Some contaminated rainwater was pumped out of the 1F evaporator cell in February 1998 and some steam to the 1F system was permanently isolated in May 1998. However, at the time of this System Plan, no chemical cleaning has been done and no decontamination and decommissioning activities have occurred. 
In 1997, 2F Evaporator system operation was interrupted by the same sludge source term PISA and TSR implementation issues that affected the $2 \mathrm{H}$ Evaporator system. The $2 \mathrm{~F}$ evaporator was already shut down for a two-week planned outage in May 1997 when the sludge source term concern arose in the $2 \mathrm{H}$ system. Recognizing that this concern applied to the $2 \mathrm{~F}$ system as well, the $2 \mathrm{~F}$ evaporator completed its planned outage and immediately entered a PISA outage. An aggressive sampling program determined that the existing feed in the $2 F$ system was acceptable to run through the evaporator, and $2 \mathrm{~F}$ resumed operations on July 4, 1997, with source term limitations in place. During the next six weeks, $2 \mathrm{~F}$ recovered $\sim 200,000$ gallons of space, enabling F-Tank Farm to achieve its 900,000 gallon space gain goal for FY97. By that time, the $2 F$ evaporator had reduced its existing inventory to a "liquor" state, and no additional space could be recovered by further evaporation of that material. No new feed could be transferred from the higher source term H-Tank Farm tanks into the $2 \mathrm{~F}$ system until appropriate modifications could be made to the evaporator to satisfy the sludge source term PISA. Therefore, in late August 1997, $2 \mathrm{~F}$ shut down for a planned outage. For FY97, the 2F evaporator achieved a total of $\sim 908,000$ gallons of space gain at an average utility of $60 \%$, with a peak of $97.8 \%$ in March.

A planned steam outage precluded $2 \mathrm{~F}$ operations in October 1997. In November, $-245,000$ gallons of concentrated liquor were transferred out of Tank 26 and into Tank 34, and 369,000 gallons of fresh, dilute waste were transferred from Tank 33 into Tank 26. The 2F evaporator resumed operations in mid-November 1997. During the next three months, $2 F$ recovered $\sim 233,000$ gallons of space. This is enough to support a planned transfer of $\sim 350,000$ gallons from Tank 32 to Tank 26 , currently planned in May 1998. The $2 \mathrm{~F}$ evaporator entered a planned shut down in late January 1998 to install TSR modifications and to make other necessary improvements. The 2F evaporator is expected to resume operations on May 15, 1998.

The $2 \mathrm{~F}$ evaporator currently evaporates $100 \%$ of the F-Canyon HHW and LHW, and $100 \%$ of the HCanyon HHW. Much of the backlog unconcentrated supernate from H-Tank Farm will also be evaporated in 2F. (Note: Each backlog tank has its own space gain factor, so one is not shown explicitly in the equation below.) In addition, $2 \mathrm{~F}$ will evaporate $36 \%$ of the ESP wash water (F-Area has about $36 \%$ of all sludge, thus $36 \%$ of the sludge wash water is allocated to $2 F$; plus $44 \%$ of the tank wash water (F-Area has 22 of the 51 tanks, thus $44 \%$ of the tank wash water is allocated to $2 F$ ); when these streams are generated, starting in FY99. Therefore, the algorithm used to forecast space gain for the 2F Evaporator is:

$$
\begin{array}{cl}
\text { 2F Space Gain }=\quad & (1.00)^{\star}(\text { F-LHW })^{*}(0.71)+ \\
& (1.00)^{*}(\text { F-HHW })^{\star}(0.71)+ \\
& (1.00)^{*}(\text { H-HHW })^{\star}(0.71)+ \\
& (\text { backlog supernate })+ \\
& (0.36)^{\star}(\text { ESP wash water })^{\star}(0.85)+ \\
& (0.44)^{*}(\text { tank wash water })^{*}(0.90)
\end{array}
$$

At the time of this Plan, F-Tank Farm had received $\sim 123,000$ gallons of waste from F-Canyon (FYTD), with $\sim 190,000$ gallons still expected during FY98. Two transfers of unconcentrated supernate from Tank 32 totaling $\sim 772,000$ gallons are planned in Summer 1998. In addition, $\sim 194,000$ gallons of unconcentrated supernate will be transferred from Tank 33. By evaporating this quantity of backlogged supernate and $\mathrm{F}$-Canyon waste, the $2 \mathrm{~F}$ evaporator could achieve as much as $\sim 900,000$ gallons of space gain in FY98.

Evaporation of dilute supernate from Type III tanks will continue in FY99 and FY00. Forecast backlog feed to $2 F$ in FY99 includes $\sim 597,000$ gallons of supernate from Tank 32 , and $\sim 145,000$ gallons of supernate from Tank 33. Forecast backlog feed to $2 F$ in FYO0 includes $\sim 1,000,000$ gallons of supernate from Tank 39, and $~ 300,000$ gallons of supernate from Tank 33.

HLWMD experience operating HLW evaporators indicates that the average life expectancy of evaporator vessels is 10.5 years. The $2 F$ Evaporator vessel will reach 10.5 years of service in April 2000. The plan is to operate the $2 \mathrm{~F}$ evaporator until failure, so a replacement outage is not specifically scheduled at this time. SRS must first determine whether vessel replacement is warranted, given the current condition of the installed vessel, and the schedule for permanently 
removing the $2 \mathrm{~F}$ evaporator from service. If SRS does decide to replace the $2 \mathrm{~F}$ evaporator vessel, new jumpers for the replacement vessel and a disposal box for the failed vessel must be fabricated. Also, SRS must determine whether the new vessel should be installed as is (with the stainless steel tube bundle already in place), or whether the stainless steel tube bundle should be replaced with a Hastelloy tube bundle. Both the replacement vessel with a stainless steel tube bundle and a separate Hastelloy tube bundle are already available on site.

The 2F Evaporator can be shut down around the year 2017. The small amount of waste in F-Area can then be shifted to the RHLWE for evaporation.

\subsubsection{F/H Interarea Transfer Line}

The capability to transfer between F-Tank Farm and H-Tank Farm was restored in FY96. Concentrated supernate was transferred from Tank 26 through the Inter-Area Transfer Line to Tank 34 in November 1997. Fresh feed for $2 F$ was transferred from Tank 39 through the Inter-Area Transfer Line to Tank 26, also in November 1997. Planned evaporation of H-Tank Farm dilute supernate in the $2 \mathrm{~F}$ system, and subsequent de-inventorying of the concentrated supernate from $2 \mathrm{~F}$ into $\mathrm{H}$-Tank Farm, will require numerous uses of the inter-Area Transfer Line during the period FY98FYO0. Tank 8 sludge will also be transferred to Tank 40 via the Interarea Line in FY99.

\subsubsection{F-Tank Farm Waste Removal Operations}

\section{Salt Removal}

Tank 25 will be the third salt tank fed to the Salt Processing facility. Tank 25 must be emptied and returned to salt service before Tanks 27 and 46 are filled with salt. Tank 25 will be ready for waste removal in FYOO, with the first transfer of dissolved salt solution to the Salt Processing facility occurring in FYO4. Slurry pump installation and run-in and completion of post-modification testing activities comprise the remaining Tank 25 scope.

Tank 25 will be the first F-Tank Farm tank to undergo salt removal. Prior to startup, the F-Area common area support infrastructure upgrades must be completed. These facilities include the motor control center, instrument control room, distributed control system, and bearing water makeup and distribution. Succeeding F-Area tanks will use this infrastructure.

Tank 25 may be used to demonstrate a low pressure (approximately $60 \mathrm{gpm}$ and $50 \mathrm{psi}$ ) water jet for salt dissolution. A water jet which was originally designed to clean out tank trucks will be modified to allow SRS to use manual control of the sprayer nozzle necessary to conduct "point-and-shoot" demonstrations of the water jet. The modified water jet will be tested at TNX prior to installing it in the G Riser of Tank 25. The test will evaluate the ability to accurately control spray direction, the effectiveness of the spray pattern, and its ability to dissolve saltcake from cooling coils and tank walls. Water jet installation and operation have been deferred pending availability of funding and resumption of salt processing.

\section{Sludge Removal}

Tank $\mathbf{8}$ is a dry sludge tank. A Potential Inadequacy in Safety Analysis (PISA) related to dry sludge tanks must be resolved before re-wetting of the sludge and pump installation can proceed. In addition, operating support for Tank 8 will be based in the 74F Control Room, which can only be staffed after the old $1 \mathrm{~F}$ Control Room has been destaffed. Under the 250 canister per year case, sludge from Tank 8 must be delivered to Tank 40 by mid-February 1999 to support final processing of Sludge Batch 3. However, current project schedules show the Tank 8 bulk waste removal being complete in April 1999, two and a half months behind the need date. In order to meet the midFebruary need date, F-Tank Farm preparations must proceed expediently. At the time of this System Plan, a construction contract has been awarded and construction activities supporting tank top service upgrades are in progress. Between October 1998 and the end of January 1999, the four slurry pumps must be installed and tested, so that bulk waste removal can occur between February 1999 and April 1999. Tank 8 sludge will be water washed in Tank 40. (This is a change from the last System Plan, when Tank 8 washing was expected to occur in-situ. This change has been made because calculations indicate less spent wash water will be generated if the two tanks are washed together.) After the sludge has been removed, Tank 8 will be readied to receive and store 
concentrated supernate. Under the 250 canister per year case, $-750,000$ gallons of Tank 27 concentrated supernate will be transferred to Tank 8 in FY01.

Tank 19 heel removal technology will be selected between April and September, 1999. The Waste Removal Project, tank operations and tank water washing will proceed during FYOO. Refer to Section 8.4.4 for details on Tank 19 closure plans.

During Tank Closure activities, residual waste and wash water from Tanks 20,17 and 19 is being collected in Tank 18. Heel removal technology for Tank 18 will be selected between April and September, 1999. Design will proceed from October 1999 to March 2000. Between April 2000 and March 2001, a construction contract will be awarded and construction will be completed. Startup testing will occur from April through June 2001, followed by bulk waste removal from Tank 18 to Tank 7 by the end of FYOO. Refer to Section 8.4 .4 for details on Tank 18 closure plans

Tank 7 as-built drawings are complete, and a mock-up for Riser 4 probing is complete. Completion of Riser 4 probing on Tank 7 and installation of a telescoping transfer pump in Riser 4 is on hold pending availability of resources. Under the 250 canister per year case, the waste removal design contract must be awarded and the design completed by the end of June 1999 . The subsequent construction contract must be awarded and construction completed by the end of June 2000. Slurry pumps must be installed and tested between July and mid-September 2000 , so $30 \%$ of the consolidated Tank $7 / 18 / 19$ sludge can be transferred to Tank 51 for washing with Tank 11 . The remaining $70 \%$ will be transferred to Tank 40 in FY03 as part of Sludge Batch 5 .

Tank 4 walk-downs and preparation of as-built drawings must begin in June 1998. The design contract must be awarded in FY99 and the design completed by the end of November 1999. Between December 1999 and end of May 2001, the construction contract must be awarded and construction completed. Slurry pumps will be installed and tested from June 2001 to February 2002. Bulk waste removal to Tank 40 would proceed from March 2002 to February 2003, in support of preparing Sludge Batch \#5. Under the 250 Can per year case, Tank 4 would be refilled with 750 Kgal of concentrated supernate from Tanks 38 and 13.

Work on Tank 5 and Tank 6 must begin in early FY01 to support transfer of partially washed sludge to ESP Tank 51 in FY05.

\subsubsection{F-Tank Farm New Facility Planning}

For details on projects currently planned for F-Tank Farm, please refer to Appendix D.

\subsection{Waste Removal}

\section{Waste Removal from Trpe I, II and IV Tanks}

Four different designs, or "Types," of carbon steel waste tanks are used to store liquid HLW at SRS, but only the Type III Tanks meet current requirements for leak detection and double containment as defined in the FFA. The Type I and Type II Tanks have inadequate secondary containment and leak detection capabilities, and the Type IV Tanks have no secondary containment at all. Although eleven of the non-compliant HLW tanks have leaked in the past, the HLWMD's formal tank integrity monitoring program indicates that none of the known leak sites are currently active. Still, risk to the environment will be greatly reduced by removing the waste from these tanks and immobilizing the waste in a solid borosilicate glass or stabilizing it in a saltstone waste form.

\section{Waste Removal Sequencing Considerations}

The following generalized priorities are used to determine the current sequencing of waste removal from the HLW tanks:

1) Maintain emergency tank space per the Tank Farm Safety Analysis Report (SAR);

2) Control tank chemistry, including radionuclide and fissile material inventory;

3) Enable continued operation of the evaporators;

4) Ensure blending of processed waste to meet salt processing, Late Wash, DWPF, and Saltstone feed criteria; 
5) Remove waste from tanks with a leakage history;

6) Remove waste from tanks which do not meet FFA requirements;

7) Provide continuous radioactive waste feed to DWPF;

8) Maintain an acceptable precipitate balance within the salt processing facility;

9) Support the startup and continued operation of the RHLWE; and,

10) Remove waste from the remaining tanks.

The principal goal of the Regulatory drivers is to remove waste from the old-style tanks. In the 250 canister per year case, waste will be removed from all of the old-style tanks by 2012 . However, salt waste must concurrently be removed from some of the Type III Tanks to support the cleanup of the older tanks. Salt removal from new tanks is required to maintain the evaporator systems on-line and to provide receipt space for large transfers of ESP washwater and DWPF recycle. Removal of salt from Type III Tanks $41,29,25,47$, and 38 , must receive priority over the non-compliant salt tanks to enable continued operation of the $2 \mathrm{~F}, 2 \mathrm{H}$ and RHLWE Evaporator systems. After Tank 38 , salt will be removed from the old-style salt tanks (Tanks 1, 2, 3, 9, 10, and 14), and concentrated supernate will be removed from Tanks 4,7 and 8 (if they were refilled) for feed to salt pretreatment.

\section{Tank Space Availability}

Ensuring the availability of sufficient operating space in specific tanks at specific need dates is a key consideration in the development of an operating strategy. In addition to providing safe storage of waste, additional tank space must be generated to serve as surge capacity. This recovered tank space results almost entirely from the operation of the salt processing facility. Processing dilute HLW supernate through the evaporator systems reduces the amount of space required to store waste, but does not constitute "recovered space," per se. This space gain is extremely important for the following reasons:

- to support critical site production and cleanup missions by providing tank space to receive new waste;

- to maintain the evaporator systems on-line;

- to provide space to receive the large volume, low-level radioactivity waste transfers which are a by-product of ESP, Waste Removal and DWPF operations; and,

- to ensure flexibility to handle unanticipated problems (such as a leaking tank, or sudden increase in Canyon effluents) that could require additional tank space.

The "Available Tank Space" column in Appendix G.1 is the working inventory of tank space available to support these Tank Farm activities. At the time of this Plan, the F-and H-Tank Farms have a combined 1,319,000 gallons of working space available (in addition to the 2,542,000 gallons that are always reserved for emergency spare space). A significant portion of this System Plan is dedicated to planning tank space availability.

\section{Salt Removal Technical Baseline}

The salt removal technical baseline is based on three slurry pumps per salt tank. The slurry pumps are positioned just above the saltcake, and water is added to the tank. When the slurry pumps are started, the boundary layer of salt solution in contact with the saltcake is displaced thus exposing the underlying saltcake to unsaturated water. When the water becomes saturated with salt, it is transferred to the salt processing facility. Then the slurry pumps are lowered and the process is repeated. This technique was successfully used on Tanks 17, 19, 20 and 24 . Three slurry pumps for salt removal was selected as the project baseline in the early 1980's for four reasons: the salt removal rate was fast enough to support a production rate of 405 canisters/year; the agitation provided by three slurry pumps was vigorous enough to also remove insoluble solids known to be in all salt tanks; economy of scale could be achieved by using the same pumps for salt and sludge removal; and slurry pumps were considered to be cost effective. Since that time, the cost has increased due to the use of enhanced mechanical seals and slurry pump containment.

The project cost to equip a salt tank with three standard slurry pumps, a telescoping transfer jet and the associated service and instrumentation was about $\$ 13$ million. However, this cost has been reduced to \$6-8 million through increased use of fixed price contracting and other enhanced project 
management techniques. WSRC has committed to drive the cost down below $\$ 6$ million for all salt tanks, thus driving the need for demonstrations of alternative salt removal techniques.

\subsubsection{Salt Removal Demonstrations}

The salt removal sequence is similar to previous revisions of this Plan. The planned order of nearterm salt removal is Tanks $41,29,25,47$, and 38 . This should ensure that all three evaporator systems can avoid becoming saltbound. There is flexibility in this sequence as construction of waste removal equipment for Tanks 41,25 and 29 is nearly complete. Tank 38 will be the first salt tank to employ an alternate salt removal technique and equipment. The sequence for salt removal from all salt tanks is shown in Appendix G.1.

The outyear budget for salt removal equipment has already been reduced to $\$ 6$ million per tank although SRS has not yet demonstrated a more cost effective technique than the use of three slurry pumps. The resumption of the demonstrations is tied to the resumption of salt pretreatment, presumably in FY02. There is a total of $\$ 15.5$ million in the FYOO Outyear Budget to fund salt and sludge removal demonstrations from FY02-04. Three less expensive alternative salt removal techniques have been proposed, including Modified Density Gradient, a Single Slurry Pump and a Water Jet.

In the Modified Density Gradient method, inhibited water is added to the salt tank and allowed to dissolve saltcake without agitation. Then the dissolved salt solution is removed. A Modified Density Gradient demonstration started in Tank 41 in July 1996. Approximately 44,000 gallons of supernate and interstitial liquid were removed before the test to expose the saltcake. A like amount of inhibited water was then added back to the tank. Approximately 20,000 gallons of salt was successfully dissolved, but not removed. The Tank 41 demonstration was suspended in 1996 due to processing problems and tank space concerns.

The Single Slurry Pump demonstration is also planned in Tank 41. The Single Slurry Pump method uses the same principles as traditional salt removal techniques, except that only one pump is used. Salt removal will be completed with the three slurry pumps currently installed in Tank 41.

A Water Jet, which could be used for "point-and-shoot" salt dissolution, will also be demonstrated in a salt tank. Demonstration objectives include use of different nozzles to effect different spray patterns, varying the flow rate, pressure, temperature and determination of corrosion inhibiter requirements.

Demonstration results may indicate that a combination of two or more techniques must be used to remove salt and insolubles as quickly and thoroughly as needed.

\subsubsection{Sludge Removal Demonstrations}

The technical basis for sludge removal uses four standard slurry pumps, one telescoping transfer pump and one telescoping transfer jet for each sludge tank. The project cost to equip a tank for sludge removal is $\$ 8-11$ million (FY98 constant year dollars). Two alternate sludge suspension technologies are being developed via the Tanks Focus Area: the Advanced Design Mixer Pump and AEA Technologies pumps and samplers. SRS will be expected to support these demonstrations. There is a total of $\$ 15.5$ million in the FYOO Outyear Budget to fund salt and sludge removal demonstrations from FY02-04.

The Advanced Design Mixer Pump is the product of a three-year joint development effort between SRS and Hanford. The new pumps were designed to be larger capacity mixers, more reliable and easier to decontaminate and repair, thus minimizing personnel exposure, maintenance costs, and reducing pump disposal costs. A prototype of this design has been fabricated by a vendor and has been successfully tested at TNX. The pump will be installed in a Hanford waste tank for further evaluation.

A variety of AEA Technology's sludge mixing pumps and samplers are being considered for possible application in SRS sludge tanks. All of these pumps and samplers are in use at British Nuclear Fuel's Sellafield plant in England. The appeal of these components is that they are commercially available, 
and they use compressed gases to create vacuum or pressure to move waste; thus, there are no moving parts submerged in the waste thus making the equipment virtually maintenance-free. The AEA fluidic samplers are being installed in Tanks 48 and 49 for sampling salt slurry and in Tanks 40 and 51 for sampling sludge.

\subsubsection{HLW System Upgrades}

There are two sub-projects under the Waste Removal Line Item and three other Line Item Projects that will provide the necessary upgrades to F-Tank Farm, H-Tank Farm, DWPF, Salt Processing and Late Wash to enable the HLW System to operate at an acceptable attainment rate and with minimal unplanned outages. The total funding of $\$ 287$ million (FY98 constant year dollars) is spread over the period from FY96 to FY19. Each is discussed below even though the three other Line Items are not currently part of the Waste Removal Line Item.

\section{Waste Removal Line Item Vitrification Infrastructure Upgrades}

Two upgrades are planned. The first one is a $\$ 40$ million TEC (FY98 constant year dollars) subproject from FY02-04. The second one is a $\$ 60$ million TEC (FY98 constant year dollars) sub-project from FY07-14. The objective of these sub-projects is to enable continued operation of DWPF through the end of the HLW program. Critical services and infrastructure will be systematically refurbished or replaced. Scope includes steam supply, instrument air, plant air, breathing air, well water, domestic water, distributed control systems and other equipment and instrumentation that will reach the end of its useful life and/or become obsolete.

\section{Waste Removal Line Item Precipitate Modifications}

This is a $\$ 100$ million TEC (FY98 constant year dollars) sub-project from FY00-04. The objectives of this sub-project are to enable Salt Disposition, Late Wash and DWPF to support precipitate operations at the required attainment rate. There is $\$ 70$ million to modify the existing ITP facility to handle the increased benzene generation rate or to replace ITP with a new Salt Processing Facility. This funding is essentially a "placeholder" in the outyear budget as the future of Salt Disposition is unknown at this time. There is $\$ 30$ million to enable Late Wash and the DWPF Salt Cell to handle the increased benzene generation rate and to enable Late Wash to support high attainment operations. This funding is also a placeholder in the budget due to the Salt Processing uncertainties.

\section{Waste Removal Line Item East Hill Piping Uparades}

This is a $\$ 22$ million (FY98 constant year dollars) sub-project from FY00-03. The objectives of this sub-project are to enable ITP, ESP and the 2H Evaporator to operate through the end of the HLW program. Critical services and infrastructure will be systematically refurbished or replaced. Scope includes steam supply, instrument air, plant air, breathing air, well water, domestic water and other equipment and instrumentation that will reach the end of its useful life and/or become obsolete.

\section{Waste Removal Line Item Precipitate Intrastructure Upgrades}

This is a $\$ 30$ million (FY98 constant year dollars) sub-project from FY09-11. The objectives of this sub-project are to enable Salt Processing Facilities to operate through the end of the HLW program. Critical services and infrastructure will be refurbished or replaced.

\section{Tank Farm Services Upgrades}

This is an $\$ 8$ million (FY98 constant year dollars) FY96 Line ltem that will be completed in FY99. Scope includes replacement of electrical services north of the $1 \mathrm{~F}$ Control Room, installation of steam services to Tanks 29-32 and 35-37, installation of air services to the same tanks, and new separate gang valves for Tanks 35-37 and HDB-6.

\section{Storm Water Upgrades}

This is an $\$ 8$ million (FY98 constant year dollars) FY98 Line Item that will be completed in FY00. This project will provide equipment to relieve the current storm water flooding that occurs in the Tanks 9-12 area of the H-Area Tank Farm. In the past, this condition has resulted in storm water standing on top of Tanks 9-12 and actually leaking into the tanks. In a worst case scenario, a waste tank could be filled with water, causing direct communication between the tank contents and the standing water in the Tanks 9-12 area. This could also occur with the HDB-2 complex. As an interim 
measure, three-foot-tall dikes have been constructed around the perimeters of Tanks 9-12 to keep the water out.

\begin{abstract}
Tank Farm Support Services (F-Tank Farm)
This is a $\$ 19$ million (FY98 constant year dollars) FY99 Line Item that will be completed in FY02. The project will replace the aging, underground support services in the F-Area Tank Farm with new above grade lines. The original service piping systems have exceeded their useful life. The replacement services include steam, cooling water, domestic water, plant and instrument air, and breathing air. The need for this project is evidenced by the recurring, extended steam outages experienced by the 2F Evaporator since FY94. Routine three or four day outages become one and two month outages when excavations revealed whole line segments (not just isolated leaks or point failures) in unacceptable condition.
\end{abstract}

\title{
8.4.4 Closure Program
}

The Savannah River Site has begun to close HLW tanks. This is the first time anywhere in the DOE Complex that HLW tanks are being closed. SRS will close HLW tank systems under the F/H Tank Farm Industrial Waste Water Operating Permit and South Carolina Regulation R.61-82, "Proper Closeout of Waste Water Treatment Facilities." In addition, SRS recognizes that future RCRAVERCLA remediation actions may be required to clean up contaminated soils in the Tank Farms. Therefore, the SRS Tank Closure Program is structured to be consistent with the comparative analyses performed as part of a RCRA corrective measures study, and a CERCLA feasibility study under the FFA.

The performance objectives for HLW tank system closure are the groundwater protection standards applied at the point where groundwater discharges to the surface (seepline), and the surface water quality standards applied in the receiving stream. Closure options for each tank are evaluated to show conformance with the performance objectives as part of the overall evaluation.

DOE has determined that the material remaining in the tank systems at closure satisfies NRC criteria for "incidental waste," if remaining waste:

(a) "has been processed (or will be further processed) to remove key radionuclides to the maximum extent that is technically and economically practical;

(b) will be incorporated in a solid physical form at a concentration that does not exceed the applicable concentration limits for Class $C$ low-level waste as set out in 10 CFR Part 61; and

(c) will be managed, pursuant to the Atomic Energy Act, so that safety requirements comparable to the performance objectives set out in 10 CFR Part 61 are satisfied."

The general protocol for SRS tank closure is as follows. Bulk waste is removed and the tank is water washed. Any waste remaining in the tank after water washing is considered residual waste. The residual waste is characterized, and a method for stabilizing the residual contaminants is proposed. The proposed closure configuration is subjected to fate and transport modeling to evaluate compliance with overall performance objectives as determined by applicable environmental regulations. Contributions from other nearby tanks and non-tank sources are also included in the calculations. The portion of the performance objectives remaining after subtracting non-tank sources is apportioned among the tanks to determine individual, tank-specific performance objectives. Detailed tank-specific closure modules are prepared for each tank and submitted to SCDHEC for approval. SCDHEC approval is a prerequisite to starting emplacement of backfill material.

Three distinctly different layers of backfill material are placed in each tank. The first layer of backfill, nominally referred to as "reducing grout" for its waste-binding properties, was developed and tested by Construction Technologies Laboratories (CTL) in Chicago. The second layer of backfill is Controlled Low-Strength Material (CLSM), which will prevent tank subsidence. The top layer is "strong" grout, which can fill small void spaces at the top of the tank and will discourage intruders in the event institutional control is lost. 
The Tank 17-20 cluster in F-Area was selected as the first set of tanks to be closed, for several reasons. Tanks 17-20 are old-style tanks, which will not be returned to service after waste removal. Very little waste remains in any of the four tanks (see below for more details). Tanks 19 and 20 have a history of groundwater in-leakage. Also, these are Type IV tanks, which lack internal structures, thereby simplifying removal of sludge heels and emplacement of backfill material. Tank 16, an $\mathrm{H}$ Area Type II tank which has already undergone bulk waste removal, water washing and acid cleaning, also will be closed. Tanks 20 and 17 were closed in 1998.

Tank 20 was the first HLW Tank operationally closed at SRS. Bulk waste removal and water washing were completed in 1986. Ballast water was removed in July 1996. Photographic inspections of the tank interior revealed $\sim 1,000$ gallons of residual sludge on the bottom of the tank. The waste was characterized by process knowledge and sampling. SCDHEC approved the Tank 20 Closure Module on January 30, 1997. DOE-SR has determined through their ongoing interactions with the NRC that the NRC had "no objection" to the closing of Tanks 20 and 17. WSRC began placing the reducing grout in Tank 20 on April 24, 1997, using an on-site continuous feed plant located near Tank 20. The reducing grout was placed in several stages. The first layer was placed in liquid form using multiple pour locations. Grout was alternately poured through six perimeter risers and one center riser. The dense grout lifted the waste sludge, which is less dense, off of the tank bottom and spread it across the tank. The loose waste sludge was then immobilized by blowing in dry powdered grout. The dry particles hydrated, incorporating the water into the grout powder, and formed a hard mass. More liquid grout was poured from the center riser, forming a domed cap fully encapsulating the waste within the grout layers. Bleed water generation was kept to a minimum due to the special formulations of the backfill materials. A total of 518 cubic yards of liquid grout was used along with $141,620 \mathrm{lbs}$ of dry grout material. The entire filling operation was observed using a remotely operated video camera. The grouts and CLSM were shown to be very flowable while in the liquid state and were able to self-level and fully surround and enclose tank equipment. SCDHEC approved the Tank 20 closure on July 31, 1997.

Tank 17 was the second waste tank operationally closed at SRS. Bulk waste removal of 376,000 gallons of sludge was completed in 1985. Approximately 280,000 gallons of tritiated water was transferred from Tank 17 to Tank 6 in March 1997, leaving a sludge heel of $\sim 10,000$ gallons. Flygt mixers (4 horsepower and 15 horsepower sizes) were used to suspend the sludge heel, and water brushes were used to sluice the suspended sludge toward diaphragm pumps for removal to Tank 18. Approximately 2,200 gallons of solids and 200 gallons of water remained in Tank 17 after sluicing. These waste solids were sampled; sample results confirmed that process knowledge estimates were reasonable. The reducing grout was placed in several layers. The first one foot layer was placed in liquid form using multiple pour locations. When the grout was first introduced, some of the sludge was lifted off the tank bottom by the dense grout. Some intermixing occurred between the grout and the sludge. After the first one foot layer, no visible sludge remained on the top of the grout. At this point, the remaining reducing grout was poured from the center riser to achieve a total of $\sim 6$ feet ( 1,330 cubic yards) of reducing grout. This was followed by $\sim 28$ feet $(5,416$ cubic yards) of CLSM, and $\sim 11$ feet $(1,307$ cubic yards) of 2,000 psi high strength grout. The Tank risers were filled with 28 cubic yards of 5,000 psi high strength grout. SCDHEC approved the Tank 17 closure on December $15,1997$.

Tank 16 was the subject of a rigorous waste removal, water washing and acid washing demonstration in 1978-80. Waste removal from the tank primary is considered complete. However, large quantities of crystallized saltcake remain in the annulus. Some of the crystallized saltcake may have evolved into natro-devyne, a hard, insoluble compound, which would not dissolve easily. Mock-up and demonstration of a vendor's vacuum sample tool was successfully completed at TNX in April 1998. Deployment of the vacuum sample tool in the Tank 16 annulus is scheduled in May 1998. Annulus waste samples will be retrieved and analyzed, and closure performance modeling will be completed by August 1998. The performance modeling will provide data supporting the decision for additional cleaning of the annulus. Tanks Focus Area funding is being used to support FY98 activities. Tank 16 closure is currently funded in FY01 and FYO2, although this schedule could be accelerated if funding was available earlier. Closure in FY02 meets DOE's FFA commitment to close Tank 16 in FY15. 
Tank 19 bulk waste removal occurred in 1986 using two slurry pumps mounted in almost diametrically opposing risers. This equipment configuration created a "beachline" of sludge and zeolite (spent ion exchange media), roughly 18 inches high, running across the diameter of the tank bottom. The zeolite particles are large, making them difficult to remove with only two slurry pumps. Zeolite covers some piles of sludge. Waste samples obtained with a mud snapper in 1995 revealed that the heel is soft and probably easily mobilized. Therefore, the current plan for Tank 19 heel removal is to use essentially the same type of water brushes and Flygt mixers previously deployed in Tank 17. However, in this case, larger Flygt mixers would be needed. A 50 horsepower size mixer is currently being tested for that purpose; testing is expected to be complete by the end of July 1998. Because of the presence of zeolite in Tank 19, SRTC has enhanced a vendor's remote crawler and is testing it for possible deployment in Tank 19. The residual waste and wash water from Tank 19 will be consolidated in Tank 18. The Tank 19 transition box has been built but not yet installed. As with Tank 16, Tanks Focus Area funding is being used to support most FY98 activities. Tank 19 closure is currently funded in FY01 and FY02, although this schedule could be accelerated if funding was available earlier. Closure in FY02 meets DOE's FFA commitment to close Tank 19 in FY03.

Tank 18 will be the last tank closed in this cluster because: 1) Tanks 17,19 and 20 can only transfer into Tank 18, and 2) Tank 18 is the only one of the four that can transfer out to FDB-1. The tank currently contains about 42,000 gallons of sludge and 308,000 gallons of supernate. After the Tank 19 waste is transferred into Tank 18 , the combined contents of Tanks 18 and 19 will be transferred to Tank 7 and combined with Tank 7's waste for in-situ sludge washing. In support of the "Accelerating Cleanup: Paths to Closure," dated 4/98, Tank 18 will be closed in FY03. This meets DOE's FFA commitment to close Tank 18 in FYO4.

\subsection{HLW Pretreatment}

Three HLW facilities are included under Pretreatment in the FYOO Outyear Budget. They include the Extended Sludge Processing (ESP) Facility, the In-Tank Precipitation (ITP) Facility, and the Late Wash Facility. ESP is currently operating. ITP and Late Wash are down pending the results of a Systems Engineering Evaluation that will determine the best option for salt processing at SRS.

\subsubsection{Extended Sludae Processing (ESP)}

\section{General}

The ESP facility uses high temperature caustic dissolution to remove excess aluminum in sludge, which improves glass viscosity and reduces the total number of canisters to be produced; then washes the sludge with water to remove excess alkali, in order to make the sludge compatible with the vitrification process.

The current inventory of sludge in the HLW tanks will be divided into ten discreet sludge batches as shown in Appendix G.3. Each batch has been remodeled using CPES and PCCS since the last revision of this Plan and is projected to make acceptable glass. The resulting sludge batch compositions are also being checked against the DWPF WAC for compliance with the limit and target values. This review was in progress at the time of this Plan.

The current sludge inventory will produce about 5,084 canisters. Up to 150 additional canisters will result from the currently defined Canyon production plan thus the total canister count is projected to be about 5,200 versus the 5,978 canisters projected in the last revision of this Plan. This is primarily due to three factors: 1) all 10 sludge batches have been remodeled based on 4,000 pounds glass per canister versus the original basis of 3,705 pounds; 2) waste loading is consistently higher than the 27-28 wt \% design basis; and 3) the data in the Waste Composition System has been improved and incorporated into the CPES/PCCS modeling. A review of the sludge data revealed that the total mass of sludge in the Tank Farm incorrectly included some soluble species which are now not included in the sludge.

The planning basis for the ESP facility has changed. Whereas the original facility flowsheet was based on using two tanks for co-washing while a third tank fed DWPF, one tank (Tank 42) will soon be re-deployed as a storage tank for concentrated supernate and possibly as a feed staging tank for salt pretreatment. This precludes using a co-washing flowsheet. Therefore, the revised ESP 
flowsheet calls for Tanks 40 and 51 to alternate roles as processing and feed tanks. Both tanks will be retrofitted with steam spargers and caustic addition facilities to provide aluminum dissolution capability. Partial washing of sludge will be performed in-situ, e.g., in the tank where the sludge currently resides. Then the partially washed sludge will be consolidated in either Tank 40 or 51 for final washing and blending just prior to starting feed to DWPF.

\section{Production Capacity}

Sludge batch preparation, from in-situ washing and aluminum dissolution through sludge consolidation and final washing and blending is assumed to require 24 months. Settling data from Tank 51 confirms this assumption. The size of each batch is limited to 700,000 gallons at 19 wt \% solids due to the projected mixing capacity of the quad-volute slurry pumps in Tanks 40 and 51 . ESP can therefore produce 700,000 gallons of sludge feed every two years of which 612,000 gallons is available for feed to DWPF. Assuming that each canister contains 1,000 gallons of sludge, ESP can therefore support sustained production of about 300 canisters/year.

\section{Production Plan}

Tank 51 is currently feeding Sludge Batch \#1A to DWPF. At the completion of the final wash water decant and wt\% solids adjustment, Sludge Batch \#1A consisted of 491,000 gallons of washed sludge at $16.8 \mathrm{wt} \%$ total solids. Of this amount, 368,000 gallons were available to feed forward to DWPF for vitrification. The Tank 51 heel is $35^{\prime \prime}$ or 123,000 gallons based on pump elevations, net positive suction head requirements and cooling considerations. Since the last revision of this Plan, the Tank 51 transfer pump suction elevation was lowered from 61" to 31" in order to make all of the 368,000 gallons available (a minimum cover of 4 " of sludge above the pump suction is required). Also, the B4 slurry pump was replaced with a new design quad-volute pump. All four slurry pumps are now of the new design. Sludge Batch \#1A is projected to last until $8 / 30 / 98$ at the current DWPF production rate of 250 cans/year.

The Tank 42 riser $\mathrm{G}$ and $\mathrm{H}$ slurry pumps are now running properly. Each pump was raised $90^{\text {" }}$ and operated to slurry the top layer of settled sludge and then lowered in 10" increments to slurry as much sludge as possible. Tank 42 sludge washing was completed in December 1997, and the sludge was allowed to settle. Approximately 260,000 gallons of spent wash waster was decanted from Tank 42 to Tank 43 . Tank 42 currently contains $\sim 488,000$ gallons of washed sludge. This sludge will be transferred to Tank 51 during a planned two week DWPF outage in July 1998. The goal is to transfer all but 75,000 gallons. The four standard slurry pumps in Tank 42 cannot suspend all of the sludge; therefore, it is not known how much of the sludge can be transferred to Tank 51. A material balance will be completed after the first transfer. A second transfer will probably be needed. Representative sludge samples from Tank 42 are currently being vitrified and analyzed to confirm that the glass product will meet established waste acceptance criteria. Tank 42 sludge, when blended with the Tank 51 sludge heel, will become Sludge Batch \#1B.

Sludge Batch \#1B is projected to last until May 2000. By that time, Sludge Batch \#2 must be ready to feed. This batch consists of the sludge currently in Tanks 8 and 40 . Aluminum dissolution is not required so the expected duration for washing, consolidating, sampling and making test glass is 21 months. Washing must therefore start in August 1998. The schedule to support the May 2000 date is being developed. It is generally considered that the start of washing will be 4-6 months late. Options are being developed to reduce the 21 month wash duration.

Tank 40 currently houses 4 failed slurry pumps from Tank 51 . These pumps must be removed and disposed. Four quad-volute slurry pumps, already on site, will be run in and installed to prepare Tank 40 for sludge washing service. Tank 40 already contains about 170,000 gallons of unwashed sludge and about 1,000,000 gallons of concentrated supernate. The supernate will be transferred to Tanks 35 and 42 prior to transferring Tank 8 sludge into Tank 40. 


\subsubsection{Salt Processing: In-Tank Precipitation and Late Wash}

\section{General}

The ITP facility uses chemical precipitation/adsorption and filtration to separate Cs-137, Sr-90 and Pu from salt solution into a low-volume, high radioactivity waste stream known as "precipitate," and a high-volume, low radioactivity waste stream known as "filtrate." The precipitate is further processed at the Late Wash facility, which reduces the nitrite concentration of precipitate feed from ITP Tank 49 from $0.15 \mathrm{M} \mathrm{NO}_{2}$ to $0.01 \mathrm{M} \mathrm{NO}_{2}$. The lower $\mathrm{NO}_{2}$ concentration reduces the formation of organic compounds and ammonium nitrate in the DWPF melter feed preparation ventilation system to safe and manageable levels. The filtrate is combined with ETF evaporator concentrate in Tank 50 , and then solidified and disposed as Saltstone grout.

Experiments designed to enhance ITP process chemistry knowledge as recommended in DNFSB Recommendation 96-1 continued throughout 1997. Based on unfavorable results, WSRC advised DOE on January 23, 1998 that further work on the ITP process be suspended and a Systems Engineering Evaluation be completed to determine the best path forward. The Salt Processing Systems Engineering team has been formed as well as an oversight team. The evaluation is currently in progress. All known salt processing options will be evaluated against HLW System requirements and the best option will be selected. A draft schedule for the Systems Engineering Evaluation proposed September 30, 1998 as the target date by which the evaluation would be completed and a recommendation submitted to DOE-SR. As this effort has progressed and the scope of the evaluation has become more focused, a final schedule for this effort can be prepared. The final schedule, due to DOE-SR on June 22,1998 , will identify a firm completion date, which may vary slightly from the target September 30,1998 date originally proposed.

The Late Wash project is complete per the original baseline. In 1997, Late Wash was placed in a cold shutdown mode due to the ITP work suspension. The future use of Late Wash is uncertain, pending the outcome of the Systems Engineering Evaluation. If the existing ITP facility with some modifications is the chosen option, then Late Wash will need to start up within one year of ITP startup. If the chosen option is a new process, or even an ITP-like process using a smaller stainless steel tank, then Late Wash may not be needed at all. The Late Wash facility, or portions thereof, could be used to reduce the cost of the selected salt processing option.

\section{DNFSB Recommendation 96-1}

The DNFSB issued Recommendation 96-1 on August 14, 1996. The recommendation was confined to safety issues at the ITP facility. It contained two specific recommendations:

1. Conduct of the planned test PVT-2 should not proceed without improved understanding of the mechanisms of formation of the benzene that it will generate, and the amount and rate of release that may be encountered for that benzene.

2. The additional investigative effort should include further work to: (a) uncover the reason for the apparent decomposition of precipitated TPB in the anomalous experiment; (b) identify the important catalysts that will be encountered in the course of ITP, and develop quantitative understanding of the action of these catalysts; (c) establish, convincingly, the chemical and physical mechanisms that determined how and to what extent benzene is retained in the waste slurry, why it is released during mixing pump operation, and any additional mechanisms that might lead to rapid release of benzene; and (d) affirm the adequacy of existing safety measures or devise such as may be needed.

An experimental program was developed and completed at SRTC in response to the benzene problems. This program concluded that the benzene generation rate could be, under certain conditions, too high to credit fuel control as a defense-in-depth safety measure. Mitigative actions could include removal of the most active catalyst, "killing" the catalyst chemically, modifying the tank $\mathrm{H} \& \mathrm{~V}$, etc. In addition, laboratory tests indicated that cesium tetraphenylborate solids may not stay in solution as long as expected; this would affect the efficiency of the process and ITP's capability to support production objectives. WSRC recommended that all options for salt pretreatment be 
evaluated to determine the optimum path forward, rather than starting another round of modifications to the ITP facility.

\section{Systems Engineering Evaluation}

A team to perform the Systems Engineering Evaluation has been formally chartered and formed by SRS. This team consists of SRS personnel representing several disciplines, including systems engineering, process engineering, operations, waste processing, research, safety, and regulatory compliance. In addition, the team includes members from the Oak Ridge National Laboratory, academia, and the Hanford site representing research, chemistry and chemical processes, respectively. The existing ITP Flowsheet Team developed the functional requirements for salt pretreatment and will remain intact as an adjunct to the Systems Engineering Evaluation team.

Over 130 salt processing options have been proposed. The Systems Engineering Evaluation team has developed ranking criteria and weighting factors, and applied them to the original list of 130 options. At the time of this System Plan, the list has been pared down to 18 options. These will be modeled, evaluated, ranked and pared down again to just 5 or 6 options. These last 5 or 6 will then be evaluated more completely. Detailed flowsheets will be developed, laboratory experiments will be performed if needed, and some design activities may be completed. A final evaluation will be made and a recommendation forwarded to DOE in Fall 1998.

A second team was also formally chartered and is being formed by DOE-HQ to provide expert and independent oversight of the Systems Engineering Evaluation team.

\section{Production Capacity}

The capacity for the recommended salt pretreatment option is not known. This System Plan assumes that the selected salt pretreatment option eventually will be able to process the equivalent of nine 800,000 gallon ITP batches per year. Each ITP batch was projected to consist of an average of 489,000 gallons of salt solution, 294,000 gallons of dilution water, 17,000 gallons of STPB and produce 30,000 gallons of $10 \mathrm{wt} \%$ precipitate. ITP was therefore projected to produce 270,000 gallons of precipitate per year. Each canister of coupled feed was projected to contain 1,060 gallons of precipitate; therefore, ITP was projected to be able to support production of 255 canisters per year.

The Late Wash Facility may or may not be needed, depending upon the salt pretreatment option selected by the Systems Engineering Evaluation team. If the selected option utilizes Late Wash as it is currently configured, its flowsheet is expected to operate as follows. The Late Wash cycle time is expected to be 61 hours without filter cleaning and 91 hours with filter cleaning. The best estimate is that the crossflow filters will need to be cleaned after every third batch. Less cleaning may be required, particularly as precipitate absorbed dose is reduced; however, this conservative assumption is used until actual radioactive operating data is available. The batch size will be 4,200 gallons, of which 3,500 gallons is precipitate feed from Tank 49 . Two Late Wash batches will eventually go into each melter feed tank which is expected to make 6.6 canisters. The utility of the Late Wash facility was designed to be $75 \%$. Late Wash should therefore be capable producing 93 batches/year which would support production of 305 canisters/year. This is still highly theoretical, since Late Wash has yet to process one batch and interferences caused by upstream and downstream facilities are not considered (see below).

If planned canister production is 250 cans/year, then Late Wash will need to produce 76 batches/year, which is less than the theoretical capacity of 93 batches/year. This Plan assumes that Late Wash will be able to process at a rate of 76 batches/year starting FY03.

The Late Wash process is close-coupled with DWPF, meaning that there is no "wide spot " to accumulate late washed precipitate. The Late Wash process must wait for downstream tanks in DWPF to be emptied before Late Wash can transfer precipitate forward. Likewise, Late Wash cannot operate while DWPF is down. DWPF downtime is planned to be $25 \%$. The net result of the interplay between the Late Wash and DWPF flowsheet batch times is that Late Wash may become the rate limiting process in the HLW System. Current projections indicate that the maximum production rate Late Wash can consistently support as currently configured is about 200 canisters 
per year. This rate will be refined as actual production data is generated. Until more information is available, it is assumed that Late Wash can support 200 cans per year. As a contingency, $\$ 40$ million (FY98 constant year dollars) is set aside in FY02-04 in the FY0O Outyear Budget for HLW facility modifications (if needed) to support the selected salt processing option.

\section{Production Plan and Schedule}

The startup date of the salt pretreatment option is not known. For purposes of this System Plan, it is assumed that salt processing starts in FYO2 and processes the equivalent of three 800,000 galion ITP batches. Production is assumed to increase to five equivalent 800,000 gallon batches in FY03, seven 800,000 gallon batches in FY04, and then nine 800,000 gallon batches per year thereatter. This is shown in Appendix G.2.

If the Late Wash facility is needed in the future, then it would need to start up one year after ITP. Given the existing ITP flowsheet, the extra year is needed for ITP to produce enough precipitate to support continuous operations at Late Wash. The dates shown for the Initiation for Coupled Feed are based on current in-Tank Precipitation and Late Wash flow sheets and current salt loading levels in DWPF canisters. For the 250 canister per year case, and assuming the historical glass "recipe" of 6 wt\% salt oxides, 29 wt\% sludge oxides and $65 \mathrm{wt} \%$ frit, precipitate processing would stay "in balance" with sludge processing. That is, no precipitate inventory would remain at the end of sludge processing. Note that during simulant testing in DWPF, the salt loading was successfully tested up to $7.5 \mathrm{wt} \%$. Increasing the salt loading to $7.5 \mathrm{wt} \%$ would enable Late Wash to start up as late as FY05. It may also be possible to adjust the composition of DWPF frit to accommodate higher salt loading. The ability to delay the Initiation of Coupled Operations for both the 200 and 250 canister/year production rates is being evaluated along with the salt processing options. The results of this evaluation will be incorporated in the next revision of the HLW System Plan.

\subsection{Defense Waste Processing Facility (DWPF)}

DWPF is currently in "sludge-only" Radioactive Operations. At the time of this Plan, DWPF has poured a total of 373 canisters ( 64 in FY96, 169 in FY97, and 140 in FY98 to date). This represents completion of approximately $7.3 \%$ of the total number of canisters to be produced over the life of the facility.

\section{Production Capacity}

Attainment is defined as the design capacity multiplied by the design utility of the DWPF melter. DWPF was designed to support glass production at 228 pounds per hour, around the clock. Canister fill height was originally intended to be 91 ". At the 91" fill height, each canister contained 3,705 lbs of glass, and the design capacity of DWPF (i.e., $100 \%$ attainment) was calculated as follows:

$\frac{228 \mathrm{lbs} \text { glass }}{\mathrm{hr}} \times \frac{\text { canister }}{3,705 \mathrm{lbs} \text { glass }} \times \frac{24 \mathrm{hr}}{\text { day }} \times \frac{365.25 \text { day }}{\mathrm{yr}}=540 \frac{\text { canisters }}{\mathrm{yr}}$

Improvements in glass pour height monitoring technology and the desire to put more glass in each canister have enabled DWPF to increase the canister fill height. In recent radioactive operations, DWPF has succeeded in filling canisters to an average height of $96^{\prime \prime}$, which puts $4,000 \mathrm{lbs}$ of glass in each canister. Therefore, while the glass processing rate remains the same at $228 \mathrm{lbs} / \mathrm{hour}$, the maximum number of canisters that could be produced in a year becomes:

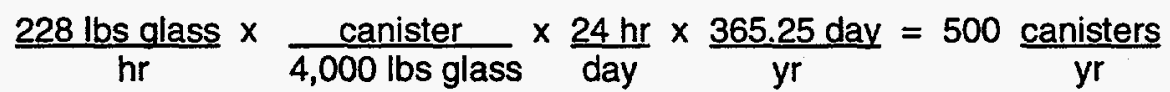

Past System Plans calculated DWPF attainment using the $\mathbf{5 4 0}$ canisters per year basis. However, DWPF attainment is now calculated using the 500 canister per year basis. This is consistent with actual plant production experience.

The design utility of the plant is $75 \%$, i.e., the plant is designed to operate $75 \%$ of the time. The assumed $25 \%$ downtime is attributed to melter replacements and planned outages. Therefore, the maximum average attainment over the long term is $(0.75)^{*}(500)=375$ canisters/year. This value is referred to as $75 \%$ attainment. 


\section{Recent Operating Experience}

Melter pour spout inserts have dramatically improved DWPF canister production rates by virtually. eliminating problems with glass "wicking." A replaceable insert is installed remotely in the melter pour spout. Its function is to provide a clean, sharp "knife edge." The knife edge is the last surface that the molten glass contacts before it free falls through the bellows and into the canister. Apparently, glass pouring had eroded the original melter knife edge, leaving a rounded surface that caused the glass pour stream to waver. This caused the glass to contact, cool and solidify on the inside surfaces of the lower pour spout and bellows liner. This greatly reduced DWPF attainment, because melter feeding and pouring had to be interrupted while the glass was removed from the affected surfaces. However, the fresh, sharp edge provided by each new insert allows the glass to flow smoothly and drop cleanly through the bellows and into the canister. The first melter pour spout insert was installed in May 1997. Operating experience shows that each insert lasts for approximately 50 canisters, before it must be removed and replaced.

\section{Production Plan}

DWPF is currently processing Sludge Batch \#1A from Tank 51 . Under the 250 Cans per year case, Sludge Batch \#1A is expected to last until 8/30/98. Sludge from Sludge Batch \#1B, currently stored in Tank 42, will be transferred to Tank 51 during a planned outage in July 1998. Sludge Batch \#1B is expected to last until $5 / 00$. For additional information on preparation of future sludge batches, refer to Section 8.5.1, Extended Sludge Processing, and Appendix G.3, Sludge Processing.

Several facility modifications are being implemented to support opportunities for production improvements:

The DWPF sludge-only flowsheet was revised to eliminate the addition of simulated precipitate hydrolysis aqueous (PHA). By eliminating the addition of simulated PHA, DWPF improved the Sludge Receipt and Adjustment Tank (SRAT) batch preparation time by $40 \%$, eliminated the need to prepare and sample the batches of simulated PHA, and reduced the volume of recycle generated by 11,000 gallons per SRAT batch cycle, thus reducing the volume of recycle transferred to the Tank Farm. This improvement was implemented with only minor facility modifications.

The Slurry Mix Evaporator (SME) operating sequence was modified to increase productivity. The spent decon frit and wash water resulting from canister decontamination is recycled to the SME for incorporation in subsequent glass batches. Previously, canister decontamination was a time-limiting item in melter feed preparation, because the SME could only accommodate spent decon frit and wash water at a rate of two canisters per day. However, under the new operating sequence, the SME can now accept up to 6 canisters' worth of spent decon frit and wash water per day. This improvement was made without the need for any facility modifications.

Holledge gauges are being replaced by wide-mouth bubblers in the Sludge Receipt and Adjustment Tank (SRAT), the Slurry Mix Evaporator (SME) Tank, the Melter Feed Tank (MFT), and the Low Point Pump Pit (LPPP) Sludge Tank. The wide-mouth bubblers can be cleaned by flushing them with water, which makes them easier to maintain (and therefore less expensive) than the Holledge gauges. The bubblers should have a much longer service life than the Hollegde gauges.

The dilute nitric acid decon system presently in use in the Remote Equipment Decon Cell (REDC) and the Contact Decon Maintenance Cell (CDMC) may be augmented by a carbon dioxide pellet system. This system would assist equipment decontamination in these two cells by generating streams of high pressure air bearing the $\mathrm{CO}_{2}$ pellets. This method must be successfully demonstrated prior to implementation in the facility. Testing is in progress and is expected to complete in late FY98. If successful, implementation of this system would reduce one source of aqueous waste in DWPF, because the spent $\mathrm{CO}_{2}$ pellets will sublime (phase change directly from solid to gas). This will help reduce the volume of recycle waste being returned to the Tank Farms, thereby reducing the burden on Tank Farm Evaporators and storage space.

Mock-up testing of laboratory aliquotting has been completed. DOE is currently reviewing WSRC plans to conduct side-by-side testing of aliquotting using real waste in the DWPF Analytical 
Laboratory. If DOE approves the plans, WSRC will have 3 months to conduct the side-by-side testing in DWPF. This should result in significant increases in DWPF Analytical Laboratory capacity.

Several additional facility modifications are needed to prepare DWPF for processing of Batch \#1B sludge. The Melter Feed Tank interlocks will be upgraded and seismically qualified to ensure that, in the event of an earthquake, feeding to the melter will stop. Motor Control Centers for Zone 1, 2, and 3 Ventilation will be seismically qualified to ensure that following an earthquake, forced air ventilation into the Vitrification building can be shut down while exhaust fans continue to operate. This will maintain negative pressure inside the Vitrification Building, thereby reducing the risk of an unfiltered release of radioactive material. A safety class air purge supply to the Slurry Mix Evaporator Condensate Tank (SMECT) is also being added to maintain a dilute vapor space. This will prevent the SMECT vapor space from reaching the lower flammability limit in the event of a solids carryover from the Sludge Receipt and Adjustment Tank (SRAT) or the Slurry Mix Evaporator (SME), which could result in hydrogen generation.

Production will escalate as follows:

$\begin{array}{ll}\text { FY96 } & 64 \text { canisters (actual) } \\ \text { FY97 } & 169 \text { canisters (actual) } \\ \text { FY98 } & 250 \text { canisters (140 poured to date) } \\ \text { FY99-17 } & 250 \text { canisters per year }\end{array}$

This represents a 5-year improvement of the HLW Program relative to the 11/97 "Accelerating Cleanup Plan" and HLW System Plan, Revision 8. Those past plans projected that DWPF production would continue for several years at a 200 canister per year rate, peak at 250 canisters per year for several years, then decline again to 200 canisters per year near the end of the program.

The current planning basis indicates that all waste will be vitrified in approximately 5,200 canisters by 2017. This figure represents 5,084 canisters which will be produced from the existing sludge inventory, plus approximately 100-150 canisters which are projected to account for future sludge receipts from the $\mathrm{F}$ and $\mathrm{H}$ Canyons for the currently defined mission. This is a significant departure from past System Plans, in which the total number of canisters to be produced typically hovered around 5,900 canisters. There are three reasons for the reduction: 1) The amount of glass placed in each canister is higher than previously projected. 2) Waste loading in glass has been optimized for each sludge batch, and is higher than previously projected. 3) Waste composition data has been refined to better differentiate between salt and sludge in those tanks that contain a significant quantity of both. The total number of canisters to be produced and the program end date will vary as more waste is slurried, representative samples are taken, and more is learned about the various processes in the HLW System. New Canyon missions, such as reprocessing of Spent Nuclear Fuel or Foreign Research Reactor Fuel, and new DWPF missions, such as can-in-canister Plutonium disposal, are not included in this Plan. Therefore, the total number of canisters to be produced is subject to change as missions and processes evolve.

DWPF will continue sludge-only processing until precipitate feed is available from the salt processing facility and Late Wash. At the time of this Plan, the salt processing flowsheet remains under evaluation. This Plan assumes that salt processing will resume processing in FY02. In the 250 Cans per year case, Late Wash start up and DWPF coupled operations would occur in FY03. In the 200 Cans per year case, Late Wash start up and DWPF coupled operations would be delayed until FY05. The different need dates are based on maintaining the sludge and precipitate feed in an acceptable balance to avoid having precipitate "left over" at the end of the HLW program.

During the first few years of coupled operations, the average attainment of DWPF, and therefore the HLW System, will be limited by Late Wash (if Late Wash is required for salt processing). As it is currently configured, the Late Wash facility is expected to limit DWPF attainment to $\sim 40 \%$, or $\sim 200$ canisters per year. However, funding has been set aside in "Accelerating Cleanup: Paths to Closure" document to improve Late Wash attainment rates. For more information, refer to Section 8.5.3. 


\section{Replacement Melters}

Ongoing vitrification operations will require periodic melter replacement. SRTC predicts that noble metals deposition (causing the electrodes to short-circuit) may be the most likely cause of melter failure. Other possible causes of melter failure include the failure of non-replaceable heaters in the riser, pour spout and lid. SRTC also predicts that melter life expectancy will average about two years. Replacement melter projects are planned accordingly. Melter replacement outages are expected to last approximately 5 months.

However, because of a Site Treatment Plan commitment to produce an average of 200 canisters per year (refer to Section $\mathbf{5 . 3}$ for more details), DWPF's annual production rate targets will not be decreased during years in which melter outages occur. In fact, DWPF's instantaneous canister production rate must be increased beyond currently demonstrated levels to compensate for production downtime associated with a melter replacement outage. To meet the STP commitment of 200 canisters per year, the instantaneous DWPF production rate (200 cans $\times 29$ month window $/$ 24 months production) must be 242 cans. DWPF is operating at essentially that rate right now. However, to meet the 250 Canister per year production planning case presented in this System Plan, the instantaneous DWPF production rate (250 cans $\times 29$ month window / 24 months production) must be 302 cans. Attainment improvements are required to operate DWPF at this rate. Funding for DWPF attainment improvements has been allocated in the outyears under the Accelerating Cleanup Plan Project SR-HL12, "HLW System Upgrades."

Melter \#1 is in service. It began operating in June 1994, was used for DWPF startup testing, and is currently in radioactive service. At the time of this Plan, Melter $\# 1$ has already reached $192 \%$ of its nominal two-year life expectancy. The long service life of Melter \#1 may be attributed, at least in part, to the low noble metals content of Sludge Batch \#1A. The noble metals content of Sludge Batch \#1B will be higher. Melter \#1 will remain in service as long as it operates normally.

Melter \#2 is on site. Construction modifications are complete, and the melter itself is ready to install. Some modifications to the Melter \#1 Storage Box and the Failed Equipment Storage Vault crane are being evaluated, but are currently unfunded. Plans and procedures to conduct the melter outage are task ready, should Melter \#1 fail. However, because Melter \#1 will be allowed to operate until failure, the Melter \#2 replacement outage is not specifically scheduled at this time .

The Melter \#3 vessel and frame and most major components are on site. Assembly began, but is currently on hold. The melter refractory has been installed, dried, and laid up inside the 105-P Reactor building. The subcontract for assembly of the pour spout is on hold; SRS now plans to do the final modifications in-house, based on lessons learned from Melter \#1 pouring experience. A few components are not yet available. The drain valve and feed tubes are still in production with a vendor. Thermocouples will be ordered, pending availability of funding. Once all components are on site, final assembly of Melter \#3 is expected to take 6 months. Overall lead time for a replacement melter project, from project inception through actual installation in the DWPF, is $\sim 5$ years.

\section{Falled Equipment Storage Vaults}

Failed Equipment Storage Vaults (FESVs) are repetitive projects required to sustain ongoing DWPF operations. Failed melters and other large failed DWPF equipment which are too contaminated to dispose in the site's Burial Ground will be contained in engineered boxes and temporarily stored in the DWPF FESVs. Each FESV can store one failed melter. Over the life of the HLW program, approximately $10 \mathrm{FESVs}$ will be needed. FESVs \#1-2 are already operational in DWPF. Additional FESVs are scheduled on a just-in-time basis. FESVs \#3-6 will be built on a line item project in FY01. FESVs \#7-10 will be built on a line item project in FY12.

\section{Recrcle Handling}

As part of normal operations, DWPF generates an aqueous recycle waste stream originating from three sources in the DWPF process: the primary (or back-up) Melter Off-Gas Condensate Tank, the Slurry Mix Evaporator Condensate Tank, and the Decon Waste Treatment Tank. These streams are collected in the Recycle Collection Tank for transfer to the Tank Farm. 
Melter Off-Gas Condensate Tank (OGCT): The melter is not designed to accommodate thermal cycling; that is, once it has been brought up to temperature, it remains heated containing a molten glass pool, even when waste feeding and glass pouring are temporarily suspended. Because the melter will always contain molten glass, the melter ventilation system must also remain operational. Several components of the melter off-gas system, including the offgas film cooler and the steam atomized scrubbers, use steam to cool and decontaminate the offgas before release to the Vitrification building exhaust system. Together, these components generate an aqueous waste stream which is collected in the primary (or back-up) OGCT. Although steam flow to the film coolers is reduced when melter pouring is suspended, at least one steam atomized scrubber operates all the time. Therefore, a portion of the recycle stream volume is generated at all times, regardless of waste processing rates.

During melter feeding and pouring, additional recycle volume is generated. The slurry feed into the melter is $45-55$ wt\% water, which flashes to steam upon entering the melter. This portion of the recycle stream is directly proportional to DWPF attainment rate; at higher attainment rates, feeding and pouring are increased, so recycle volume increases.

Slurry Mix Evaporator Condensate Tank (SMECT): The SMECT collects contaminated condensate from the Slurry Mix Evaporator (SME), the Sludge Receipt and Adjustment Tank (SRAT), and the Formic Acid Vent Condenser. The amount of aqueous waste produced by the SME and the SRAT is determined by waste processing rates and the solids content of the feed streams. In general, at higher attainment rates, more recycle waste will be produced.

Decon Waste Treatment Tank (DWTT): Contaminated aqueous waste from equipment decontamination operations is collected in the DWTT. The DWTT contents are neutralized with caustic before being pumped to the Recycle Collection Tank for subsequent recycling to the Tank Farm. This flow is variable, and depends upon the frequency of decontamination operations.

Recycle Collection Tank (RCT): The primary (and backup) OGCT, the SMECT, the DWTT, and the DWPF Analytical Laboratory sample waste streams are collected in the RCT, which has a working capacity of 8,200 gallons. DWPF has no other capacity to store the recycle stream.

Transfer to H-Tank Farm: To support DWPF production, recycle transfers to the Tank Farm must occur daily. The normal HLW System configuration for these transfers uses the S- to H-Area interarea line to the Low Point Pump Pit, then to the HDB-8 Complex, through HDB-5, and finally to Tank 43 , which feeds the $2 \mathrm{H}$ Evaporator. The same route can also be used to transfer recycle into Tank 38 when necessary. A route through HDB-8 and HDB-5 also exists, which allows the DWPF recycle to be transferred to Tank 22. At the time of this System Plan, HDB-8 and HDB-5 are being rejumpered to allow DWPF recycle to be transferred through HDB-8 and HDB-5 to Tank 21 as well. This will provide additional flexibility for the Tank Farms to accept DWPF recycle when Tank 43 is unavailable. After the RHLWE starts up, the DWPF recycle volume will be divided between the RHLWE and 2H. For more details, refer to Section 8.2.2, "H-Tank Farm Evaporators."

\section{Recycle Forecast}

DWPF Engineering has developed an algorithm for predicting recycle generation rate. The algorithm is derived from recent operating experience, including demonstrated or anticipated results of ongoing efforts to reduce recycle volume; adjustments for coupled feed operation; planned program activities, and increasing waste generation from decontamination operations as DWPF equipment ages. Three versions of the algorithm apply to the current planning basis.

For FY98, sludge-only operation: $\quad$ recycle gpm $=1.55+5.57$ (ATT)

For FY99, sludge-only operation: $\quad$ recycle gpm $=1.63+5.25$ (ATT)

For coupled-feed operation: $\quad$ recycle gpm $=2.12+7.61$ (ATT) 
where:

recycle $\mathrm{gpm}=$ the rate of recycle generation, on a continuous basis, in gallons per minute

ATT = DWPF operating rate, expressed as a fractional attainment

Note that even at zero attainment, some recycle waste continues to be generated.

For FY98 sludge-only operations, at an attainment of $50 \%$ ( 250 canisters), the recycle forecast is:

$=4.34 \mathrm{gpm}$

$=2,287,000$ gallons in FY98

For FY99 sludge-only operations, at an attainment of $50 \%$ (250 canisters), the recycle forecast is: $=4.26 \mathrm{gpm}$

$=2,236,000$ gallons in FY99

For coupled-feed operations, at an attainment of $50 \%$ (250 canisters/yr), the recycle forecast is: $=5.93 \mathrm{gpm}$

$=3,114,000$ gallons per year

\section{Organic Waste Storage Tank (OWST)}

Under the current salt processing flowsheet, washed precipitate transferred from Late Wash to DWPF will contain cesium tetraphenylborate and potassium tetraphenylborate. DWPF will use a precipitate hydrolysis process to destroy the tetraphenylborate, because tetraphenylborate cannot be processed through the melter. The precipitate hydrolysis process will yield a side stream nominally referred to as "benzene," although it also contains approximately $15 \%$ other aromatic organic compounds and very low levels of radioactivity. The benzene will be steam-stripped in the Precipitate Reactor (PR), further decontaminated in the Organic Evaporator (OE), sampled in the Organic Evaporator Condensate Tank (OECT), and transferred outside the Vitrification building to the Organic Waste Storage Tank (OWST) via a welded, stainless steel overhead line.

The OWST is a double-shell, above-ground tank located south-west of the Vitrification Building in SArea. The primary tank is constructed of $304 \mathrm{~L}$ stainless steel, and has a capacity of 150,000 gallons. A floating roof inside the primary tank reduces evaporation of the organic liquid. The roof begins to float when the tank inventory reaches approximately 13,800 gallons. Therefore, a minimum heel of 13,800 gallons of benzene, once established, will always be maintained to limit benzene emissions. The vapor space between the floating roof and the fixed roof is padded with nitrogen gas, and ventilated through a HEPA filter. The secondary tank is constructed of carbon steel, and includes a leak detection system.

Benzene was first transferred into the OWST in March 1993, during DWPF Cold Runs. At the time of this System Plan, the OWST liquid organic inventory is approximately 10,000 gallons. The OWST is operated in accordance with its own RCRA Part B permit. RCRA requirements limit storage of RCRA wastes to no more than one year. After one year, the owner/operator bears the burden of proving that such storage was solely for the purpose of accumulation of such quantities of waste to facilitate proper recovery, treatment or disposal. In the past, WSRC received written permission from SCDHEC to store the DWPF benzene in the OWST beyond the normal one-year prohibition. However, on March 3, 1998, SCDHEC sent WSRC a Notice of Violation (NOV) regarding benzene storage in excess of the one-year prohibition. Discussions with SCDHEC are ongoing.

RCRA regulations recognize incineration as the Best Demonstrated Available Technology (BDAT) for treatment of benzene wastes. The Consolidated Incineration Facility (CIF), located south of the OWST, will incinerate the DWPF benzene stream. The OWST is connected to the Consolidated Incineration Facility (CIF) by a second welded, carbon steel overhead line. For more information on the CIF, refer to Section 8.10. 


\section{Mercury Disposal}

The sludge contains mercury, which must be removed prior to vitrification. Originally, the mercury was supposed to be returned to the Separations facilities for re-use in their processes, but evolving Site missions have precluded re-use of the mercury stream. Since mercury is a toxic hazardous waste under the Resource Conservation and Recovery Act (RCRA), it must be disposed in compliance with RCRA regulations. The current Best Demonstrated Available Technology for mercury disposal is amalgamation. However, radioactive contaminants in the DWPF mercury stream may necessitate pre-treatment before amalgamation, or they may preclude amalgamation. After a sufficient quantity of radioactive mercury has been recovered, samples will be collected and tested to verify which disposal options are technically feasible. Disposition of the DWPF mercury was evaluated on a national basis under the Site Treatment Plan. The DWPF mercury will be stored at an on-site, permitted storage facility until a disposition plan is finalized.

\subsection{Glass Waste Storage}

The canisters of vitrified HLW glass produced by DWPF are stored on-site in dedicated interim storage buildings called Glass Waste Storage Buildings (GWSBs). GWSB\#1 consists of a belowgrade, seismically-qualified concrete vault which contains support trames for vertical storage of 2,286 canisters. The storage vault is equipped with forced ventilation cooling to remove radioactive decay heat from the canisters. A standard steel frame building encloses the operating area directly above the storage vault. A 5-foot thick concrete floor separates the storage vault from the operating area. The Shielded Canister Transporter (SCT) moves one canister at time from the Vitrification Building to the Glass Waste Storage Building. It drives into the operating area, removes the shielding plug of a pre-selected storage location, lowers the canister into the storage vault, and replaces the shielding plug.

Of the 2,286 canister storage positions nominally available, 572 positions are currently unusable because the plugs are out of round relative to the floor liner. This poses the problem of potentially jamming a plug during removal or replacement. Of the 572, DWPF Engineering estimates that 450 plugs can be repaired, but the remaining 122 will be abandoned in place, because it is not cost effective to repair them. In addition, 5 positions are occupied by test canisters strategically located to monitor for possible corrosion. After the 450 plugs are repaired, GWSB\#1 will have a working capacity of 2,159 usable storage locations.

GWSB \#1 is currently in Radioactive Operation. At the time of this Plan, GWSB\#1 was storing 308 radioactive canisters. If DWPF production proceeds at a rate of 250 canisters/year, GWSB\#1 will reach capacity in FY05, as shown in Appendices F and G.5. (Note that this System Plan does not include potential storage of $\sim 300$ canisters from the West Valley Demonstration Project. For additional information on potential storage of West Valley canisters at SRS, refer to Section 10.1, below.)

The project to design and construct Glass Waste Storage Building (GWSB) \#2 will begin in FY01 and will be funded over a four year period. The project could be completed more quickly, but the four year period levelizes the funding requirement. GWSB \#2 design will be similar to GWSB\#1, but the capacity of GWSB\#2 will be sized to accommodate the number of canisters that will be produced between FY05 and FY15.

In accordance with the FYOO Outyear Budget, this System Plan assumes that the Federal Repository will be ready to receive canisters starting in FY15. Therefore, SRS plans to ship 500 canisters per year to the Federal Repository starting in FY15. DWPF canister production will continue at the rate of 250 canisters per year through FY17. Additional storage capacity for the canisters produced between FY15 and FY17 need not be designed into GWSB\#2, since shipment of older canisters to the Repository will free up storage space. GWSB\#2 would be emptied and available for decommissioning in FY20. GWSB\#1 would be emptied and available for decommissioning in FY25. SRS canister shipments to the Repository will be completed in FY25. Note that delays in the startup of the Federal Repository, or changes in the assumed number of canisters to be shipped each year, could increase GWSB\#2 storage capacity requirements and decommissioning dates. 


\subsection{Effluent Treatment Facility (ETF)}

The ETF treats the low level aqueous wastes from the $\mathrm{F}$ - and $\mathrm{H}$-Canyons and the $\mathrm{F}$ - and $\mathrm{H}$-Tank Farms, which used to be disposed to seepage basins. Additional waste streams from Environmental Restoration and Reactors are also treated.After treatment at ETF, the waste water is discharged to a permitted outfall at Upper Three Runs Creek.

Production Capacity: The ETF Facility includes process waste water collection tanks, treated water tanks, and basins to collect contaminated cooling water and storm water run-off. Treatment processes include $\mathrm{pH}$ adjustment, filtration, organic removal, reverse osmosis, mercury removal and ion exchange. Recent operating experience indicates that average through-put is approximately 100 $\mathrm{gpm}$, with a peak rate of $170 \mathrm{gpm}$ for short periods of time.

Production Plan: ETF plans to treat $18,000,000$ gallons of waste water in FY98. At the time of this Plan, the facility has treated $\sim 13,000,000$ gallons (FYTD).

The ETF process flowsheet has been impacted by benzene concerns in ITP. Benzene modifications at ITP were expected to preclude ETF's use of Tank 50 to receive the ETF evaporator concentrate. A new Tank 50 Valve Box was constructed and installed in FY98 to accommodate ETF's present need to transfer into Tank 50. In the future, the Tank 50 valve Box will enable ETF to transfer evaporator concentrate directly to Saltstone. There was a brief period during the tie-in of the ETF transfer lines to the valve box when transfers to Tank 50 were precluded. During that period, approximately 31,000 gallons of ETF concentrate was transferred directly to Tank 43 instead. Installation of the valve box has since been completed, and ETF has resumed making concentrate transfers to Tank 50. The current inventory of waste in Tank 50, approximately 300,000 gallons, will be transferred to Saltstone for processing in FY98. This will provide approximately 4-5 years' worth of storage capacity for ETF concentrate in Tank 50 , pending resumption of salt processing.

The H-Area Retention Basin liner will be repaired in FY98, pending availability of funding. This liner has been in service for 21 years, far in excess of its predicted 10 year life. A subcontractor will install a new liner over the old one. No facility downtime is anticipated during the liner repair work. In addition, the Cooling Water Basin Liners also will be replaced in the next few years.

\section{$8.9 \quad$ Saltstone Facility}

The Saltstone Facility treats and disposes two low-level radioactive waste streams. The ITP filtrate stream and the ETF concentrate stream are treated by mixing the wastes with cement, flyash and slag. The resulting grout is disposed by pumping it to engineered concrete vaults and allowing it to cure. The solidified waste form is known as saltstone.

Production Capacity: The Saltstone facility is normally staffed with one ten-hour shift per day, four days per week. About seven hours each day are available for salt solution processing at an instantaneous rate of up to $110 \mathrm{gpm}$. The other three hours each day are required for startup preparations in the morning and process shutdown at the end of the day. The plant utility is assumed to be $50 \%$ based on experience to date. Therefore, when feed is available, Saltstone can average $-23,100$ gallons of salt solution processed per day or $\sim 4,805,000$ gallons of salt solution processed per year.

Production Plan: Since ITP began its CLFL outage in 1996, less feed has been available to Saltstone, so waste receipt and processing operations have been reduced to the minimum level needed to "exercise" the plant. The current waste inventory in Tank 50, approximately 300,000 gallons, will be processed in FY98. This will provide approximately 4-5 years' worth of storage capacity for ETF concentrate in Tank 50 , pending resumption of salt processing.

In FY99, the Saltstone Facility will be placed in a partial lay-up mode, pending resumption of salt processing. Partial lay-up will reduce facility costs while minimizing potential deterioration of the plant, thereby minimizing the cost to resume operations in the future. Key Saltstone Facility personnel will be cross-trained to support other key missions on site, but they will return to Saltstone when needed to operate the facility. 
The future salt processing flowsheet is not known; therefore, the production requirements for Saltstone are not known. This HLW System Plan assumes salt processing will resume in FY02, and that the process will generate decontaminated salt solution similar to ITP. The feed is expected to ascend from 2,400,000 gallons in FY02 to 7,100,000 gallons in FY05 where it will remain until the end of the program. This HLW System Plan assumes Saltstone will alter its staffing plan to support these production levels.

Attainment Modifications: Some facility modifications were proposed to support Saltstone's closecoupling with ITP. A grout delivery manifold and additional valves are needed to enable Saltstone to pump grout into multiple vault cells without interrupting production. Upgraded cameras are also needed in the vault cells to monitor pouring in progress. These modifications were placed on hold until the future of salt processing is determined.

Benzene Modifications: As a result of the benzene concerns in ITP, some modifications were planned for the Saltstone Facility. These potential modifications included nitrogen inerting systems for the Salt Solution Hold Tank (SSHT) and the Flush Water Receipt Tank (FWRT); a portable benzene analyzer for the SSHT; a gear box or variable speed drive for the SSHT agitator; a flow indicator of the SSHT ventilation system; and removal of the SSHT insulation. The SSHT ventilation flow indicator will need to be monitored every 12 hours to ensure adequate ventilation is maintained. An administrative procedure will also be implemented to maintain the SSHT level at less than 45,000 gallons. This combination of measures will ensure that the time to reach LFL in either tank is greater than one day, thereby providing personnel with sufficient time to respond with mitigating measures, rather than relying on installed, engineering equipment. These modifications were also placed on hold until the future of salt processing is determined.

Vaults: Saltstone operations require periodic construction of additional vaults, capping of filled vault cells and construction of permanent vault roofs. The required schedule for these repetitive projects is dependent upon the salt processing production plan. Each vault cell can hold 232,000 cubic feet of saltstone grout, or approximately 1.1 million gallons of Tank 50 salt solution. The construction and startup of new vaults supports planned Salt Processing production rates (based on the current ITP flowsheet) on a just-in-time basis (refer to Appendix G.2).

Currently, construction of Vault \#1 is complete and the vault is in service. Vault \#1 has 6 cells, three of which are now filled. The Rolling Weather Protection Cover (RWPC)is currently covering two of the three filled cells. Therefore, grout filling in Vault \#1 has been suspended pending completion of capping of the two full cells.

Vault \#4 grout filling is now in progress, in lieu of filling Vault \#1. Eleven of Vault \#4's twelve cells are available for grout disposal (Cell $A$ was filled in 1989 when 10,032 Naval Fuels waste drums were disposed and grouted in place.) Construction of the Vault \#4 permanent roof was completed in January 1997. The permanent roof provides several advantages over the RWPC: the cells can be filled to height of $\sim 25$ feet; more than one cell can be filled at a time; and the need to dispose of the RWPC as radioactive waste is eliminated.

The design for Vault \#2 is complete. Like Vault \#4, Vault \#2 has been designed with twelve cells. However, the Vault \#2 design differs somewhat from the Vault \#4 design in that it includes a permanent roof as an inherent part of the vault design and construction. The Vault \#2 design is considered the prototype for future Saltstone vaults, if SRS chooses to continue building this type of disposal unit. (See the Saltstone Vault Alternatives discussion below for more details.) However, to maximize budget efficiencies, this Plan assumes that 6-cell vaults will be used until such time as a better planning basis is available.

Saltstone Vault Alternatives: The high cost of building replacement vaults (currently projected at $\$ 11,500,000$ for a six-cell vault, in FY95 dollars), has been identified as a potential area for cost reduction. The "Saltstone Vault Alternatives Study" identified grout disposal in a Z-Area landfill as a possible option. The subsequent "Pre-Conceptual Design Study for Z-Area Saltstone Waste Disposal Alternatives," dated October 1996, briefly described the design and construction of Geosynthetic Lined Waste Disposal Cells, which would be similar to municipal landfills. Based upon 
pre-conceptual design information, a cost comparison concluded that the landfill option could provide cost savings. However, feasibility studies of this option are on hold until the DOE Order 5820.2A requirement to conduct a Performance Assessment can be completed. Further design work will be accomplished prior to construction of the next Saltstone vault.

\subsection{Consolidated Incineration Facility (CIF)}

The Consolidated Incineration Facility (CIF) treats and volume-reduces incinerable hazardous, lowlevel radioactive and mixed SRS wastes. The EPA recognizes incineration as the Best Demonstrated Available Technology (BDAT) for treating certain hazardous components, some of which are contained in SRS waste streams. Incineration reduces the waste volumes by approximately $90 \%$, reduces the chemical toxicity of the wastes, converts the residual ash to an environmentally immobile form, and eliminates the need for off-site shipments of incinerable wastes. CIF incinerates a flexible variety of SRS-generated wastes in parallel, thereby reducing overall operating costs. Typical waste streams processed or scheduled to be processed in CIF include: job control wastes (gloves, protective clothing, spill cleanup materials); waste oils; contaminated aqueous wastes; used or excess solvents; organic wastes (including DWPF benzene, see details below); miscellaneous waste sludges; and a multitude of small volume legacy hazardous and mixed liquid waste streams arising from separations and clean-up projects around the site. CIF is a fundamental element in the SRS strategy to reduce the legacy of backlogged wastes, but also plays a key role in treating newly generated wastes as they arise, to avoid generating a new legacy problem.

Major components of the CIF include: a CIF Tank Farm for receipt, sampling and analysis of liquid wastes; a Box Handling area for the receipt and inspection of boxed solid waastes; the Incinerator itself, comprising a rotary kiln (RK) and a secondary combustion chamber (SCC); an offgas treatment system, and a secondary waste stabilization system for incineration residuals. Boxes of solid waste are fed into the RK by a mechanical ram feeder. The rotating action of the RK

continuously tumbles the boxes to ensure thorough destruction at the operating temperatures of $1,500-1,700^{\circ} \mathrm{F}$. Liquid wastes (with the sole exception of DWPF benzene, see below) are also fed to the RK via one of two available injection systems, one for organic wastes with heating values above 7,500 BTU and one for aqueous wastes with lower heating values. Combustion gases generated in the rotary kiln are further incinerated in the SCC to ensure thorough destruction of the organic waste components. The SCC operates within the range $1,800-2,000^{\circ} \mathrm{F}$. Under the currently permitted operating conditions, CIF has demonstrated $99.999 \%$ destruction of the hazardous organic constituents of waste.

CIF generates two residual waste streams: ash formed as a combustion product in the RK and blowdown liquids from the recirculation of scrubbing and cooling water in the off-gas clean-up system. These two waste streams are stabilized at CIF by encapsulation in a cement matrix to form a solid monolithic structure in $\mathbf{5 5}$ gallon drums. This stabilization process, known as the ashcrete process, uses a formulation and a process which has been demonstrated to treat these waste streams to meet LDR treatment standards. The ashcrete (made from ash) and blowcrete (made from blowdown) products produced at CIF are disposed in compliance with applicable EPA and SCDHEC regulations. Wastes derived from the incineration of listed mixed wastes are being temporarily stored at SRS prior to selection of a final disposal option in a RCRA permitted disposal facility. Wastes derived from the incineration of low-level radioactive waste or characteristic mixed waste will be disposed at SRS in the E-Area vaults. As a cost-saving measure, and as part of the integration of several of the support facilities to the HLW system, it has been determined that blowdown arising from the incineration of low-level radioactive and characteristic hazardous/mixed waste may be treated at ETF and stabilized in-bulk at the Saltstone facility, rather than being stabilized in drums at CIF.

CIF is available to provide essential support to the High Level Waste System by incinerating the DWPF benzene stream. An overhead, welded carbon steel recirculating transfer loop connects the DWPF Organic Waste Storage Tank (OWST) to the CIF. A branch connection from the loop line feeds the benzene directly to the secondary combustion chamber in CIF. A cost savings is achieved as a result of this design because any benzene burned in the SCC reduces the amount of fuel oil necessary to maintain the SCC at its operating temperature. 
A second waste stream is also directly fed to the CIF, this time to either of the injection systems in the RK. In recognition of the significant commitment that SRS has made in the Site Treatment Plan with respect to treating the legacy PUREX waste, a pipeline will be completed in FY98 to transfer the PUREX solvent from the New Solvent Storage Tanks directly to the RK in the CIF. This is a significant cost savings over the alternative drum or tanker transfers and is indicative of the importance that SRS attaches to fulfillment of its STP commitments.

CIF conducted its Trial Burn from April 14-20, 1997, and is awaiting the issuance by SCDHEC of its final RCRA Permit, which will incorporate the demonstrated results from the trial burn. In the interim, CIF is able to operate under its existing RCRA permit and since radioactive start-up on April 24, 1997, CIF has treated listed mixed wastes in support of the Site Treatment Plan commitment to treat non-PUREX legacy wastes. As a result of the success of CIF, SRS will meet its STP commitment to treat $50 \%$ of the non-PUREX legacy mixed wastes by $4 Q$ FY98. Following completion of the listed campaign, CIF will undertake a clean-out outage to transition the facility to non-listed status before commencing its next incineration campaign. The focus of the next campaign will be characteristic waste and will include the treatment of PUREX solvent (to fulfill the STP commitment) and solid low level radioactive waste.

\subsection{Technology Development}

Since 1996, DOE's Tanks Focus Area (TFA) has provided "seed money" for sites to pursue and develop technologies for which there are applications throughout the DOE Complex. In exchange for receiving TFA funding, sponsoring sites are typically required to furnish skilled labor, equipment, materials, and matching funds to execute the agreed-upon work scope. Recently, TFA funding was used to develop and demonstrate several types of new waste heel removal tools which were successfully deployed in Tank 17. Each year, participating sites provide technology development proposals to the Tanks Focus Area. The proposals are ranked together at the national level, with the top proposals selected to receive TFA funding.

Funded activities in FY98 include:

- Tank 19 heel removal

- Tank 16 annulus sampling, analysis and performance assessment

- DWPF recycle clean-up using crystalline silico-titanate resin and reduced Tank Farm storage

- Re-use of ETF carbon containers

For FY99, HLWMD submitted technology development proposals for TFA consideration. Initiatives expected to be funded are:

- Tank inspection technology

- Optimized glass waste loading

- Tank 19 heel removal

- Tank 16 annulus cleaning

- Salt Processing alternatives

- DWPF recycle reduction

- Sintered metal filters to replace waste tank HEPA filters

- $2^{\text {nd }}$ generation DWPF melter

- Methods to unplug HLW transfer lines

- Real time wt \% solids measurement device

- In-tank corrosion probe 


\subsection{Support for Future Missions}

A number of new programs are currently being evaluated or developed. Many of these programs have the potential to impact HLWMD operations in the future. At the time of this System Plan, there has been no decision to incorporate any of these programs into the baseline; therefore, none are included in the current System Plan. They are addressed in this Plan for information only.

\subsection{Receipt of West Valley Canisters}

The West Valley Demonstration Project (WVDP) in New York State began producing vitrified waste glass canisters in July 1996. Canister production will continue through FY99, by which time the entire WVDP high level liquid waste inventory will be immobilized in $\sim 300$ glass canisters. Currently, these canisters are being stored in a modified process building cell on the West Valley Site, pending availability of the Federal Repository in FY15. However, final decontamination and decommissioning of all WVDP facilities is expected to be complete by FY05, ten years before the Repository will be available. Significant cost savings could be achieved if the WVDP canisters can be shipped and stored at the DWPF GWSB\#1. The proposed plan is to ship WVDP canisters to DWPF at a rate of 100 canisters per year starting FY02 and finishing FY04.

In order for DWPF to receive and store the WVDP canisters, DWPF must repair the inoperable canister storage locations in GWSB\#1; initiate a project to design, construct, and operate a canister shipping/receiving facility; and accelerate design and construction of GWSB\#2 by one year, from FY05 to FY04.

DOE has provided $\$ 2.7$ million to HLWMD in FY98 to further evaluate this option. Activities are in progress to:

- Initiate a project to repair the inoperable storage locations in GWSB\#1;

- Coordinate canister specifications with WVDP;

- Identify interface issues regarding transportation methods (rail vs. truck, cask configuration, canister contamination levels, and canister orientation);

- Coordinate WVDP shipping schedules with DWPF production schedules;

- Initiate a plan for WVDP canister handling, which have a different nozzle design and will require a different grapple;

- Identify conceptual design requirements of a canister shipping/receiving facility;

- Evaluate the impact on DWPF operating permits;

- Determine the scope of changes to DWPF Authorization Basis documents; and

- Support revisions of NEPA documentation as appropriate

DOE is responsible for other actions, including selecting the transportation method (rail or truck), obtaining agreements with affected states regarding transportation issues; providing a qualified shipping cask; obtaining a shipping contract; and implementing any necessary NEPA activities. DOE is expected to make a final decision on this proposal in FY98.

\subsection{Can-In-Canister Plutonium Disposal}

With the end of the Cold War, the U.S. has been left with an excess of weapons-grade plutonium. Up to 50 metric tons may be suitable for disposition via a process aptly titled "can-in-canister." At the time of this System Plan, the preferred option is to construct a facility at SRS, probably within the existing F-Area, to convert the plutonium to a ceramic form. The plutonium ceramic would be placed in small stainless steel cans, measuring approximately 21 " high and approximately 3 " in diameter. These small cans could then be positioned in racks that would fit inside a full-size DWPF canister. HLW glass would then be poured into the DWPF canister as usual. The presence of the HLW glass would act as a deterrent to the unauthorized retrieval of the weapons grade plutonium. The filled canisters would then be stored in the Glass Waste Storage Building, pending transfer to the Federal Repository for long-term storage. This process was successfully tested at DWPF in 1996 (prior to the start of Radioactive Operations) using a simulated plutonium glass inside the small cans. Test results indicated that the HLW glass flowed around the cans without creating any significant void spaces, and cooled without forming many crystals. Development of this option is ongoing, and could be implemented in DWPF in FY06. Disposal of all 50 metric tons of plutonium would produce approximately 210 additional DWPF canisters. However, because this mission is still under development, these additional canisters are not included in the System Plan at this time. 


\subsection{U-233 Processing}

Oak Ridge and Idaho have significant quantities of U-233. Options will be evaluated to determine the optimum disposition of this material. The schedule at this time is as follows. By 4/17/98, SRS will provide DOE-MD the cost and schedule for evaluating the proposed options. The evaluations will begin upon DOE-MD approval of the cost and schedule. The evaluations must be completed by 9/30/98 to support development and completion of an EIS in FY99, with an ROD in FYOO. Options involving SRS include: a) dissolving the U-233 in the Canyons, diluting the U-233 with depleted U and sending the waste to the HLW tanks; b) separating Th-229 for future medical use; c) converting U-233 to an oxide and sending it to the Waste Isolation Pilot Plant; and d) packaging breeder reactor fuel pellets in DWPF canisters similar to the plutonium can-in-canister proposal. All of these options will result in the production of additional DWPF canisters. Because this mission is still under development, these additional canisters are not included in the System Plan at this time. 


\section{Appendix A - Acronyms}

\begin{tabular}{|c|c|c|c|}
\hline ACP & Accelerating Cleanup Plan & ITP & In-Tank Precipitation \\
\hline ADS & Activity Data Sheet & Kgal & Kilo-galions $=1,000$ gallons \\
\hline AOP & Annual Operating Plan & LCO & Limiting Condition of Operation \\
\hline $\mathrm{BA}$ & Budget Authority & LHW & Low Heat Waste \\
\hline $\mathrm{BIO}$ & Basis for Interim Operations & $\mathrm{LI}$ & Line Item \\
\hline BO & Budget Outlay & LIMS & Laboratory Information Management System \\
\hline $\mathrm{CAB}$ & Citizen's Advisory Board & LHW & Low Heat Waste \\
\hline CERCLA & Comprehensive Environmental Response, & LLW & Low Level Waste \\
\hline & Compensation and Liability Act & NEPA & National Environmental Policy Act \\
\hline CIF & Consolidated Incinerator Facility & NMS\&S & Nuclear Materials Stabilization and Storage \\
\hline $\mathrm{Ci} / \mathrm{gal}$ & Curies per gallon & NRC & Nuclear Regulatory Commission \\
\hline CLFL & Composite Lower Flammability Limit & ORR & Operational Readiness Review \\
\hline CLSM & Composite Low Strength Material & PCCS & Product Composition Control System \\
\hline CPES & Chemical Process Evaluation System & PCO & Process Controls of Operation \\
\hline CTS & Concentrate Transfer System & PIMS & Process Information Management System \\
\hline DCS & Distributed Control System & PISA & Potential Inadequacy in Safety Analysis \\
\hline DNFSB & Defense Nuclear Facilities Safety Board & PUREX & Plutonium Recovery and Extraction \\
\hline DOE & Department of Energy & RBOF & Receiving Basin for Off-site Fuels \\
\hline DWPF & Defense Waste Processing Facility & RCRA & Resource Conservation and Recovery Act \\
\hline EA & Environmental Assessment & RHLWE & Replacement High Level Waste Evaporator \\
\hline EIS & Environmental Impact Statement & SAR & Safety Analysis Report \\
\hline EM & $\begin{array}{l}\text { Environmental Restoration and Waste } \\
\text { Management, usually as a suffix to DOE }\end{array}$ & SCDHEC & $\begin{array}{l}\text { South Carolina Department of Health } \\
\text { and Environmental Control }\end{array}$ \\
\hline EPA & Environmental Protection Agency & SGF & Space Gain Factor \\
\hline ESP & Extended Sludge Processing & SR & Savannah River - usually a suffix to DOE \\
\hline ETF & Effluent Treatment Facility & SRS & Savannah River Site \\
\hline FESV & Failed Equipment Storage Vault & SRTC & Savannah River Technology Center \\
\hline FFA & Federal Facility Agreement & SS/SC & Safety Significant / Safety Class \\
\hline FY & Fiscal Year & STP & Site Treatment Plan \\
\hline FYTD & Fiscal Year To Date & STPB & Sodium Tetraphenylborate \\
\hline GS/PS & General Service / Process Service & TEC & Total Estimated Cost \\
\hline GWSB & Glass Waste Storage Building & Tk & Tank \\
\hline HHW & High Heat Waste & TSR & Technical Safety Requirement \\
\hline HLW & High Level Waste & WCS & Waste Characterization System \\
\hline HLWIFM & High Level Waste Integrated Flowsheet Model & WRP\&S & Waste Removal Plan and Schedule \\
\hline HLWMD & High Level Waste Management Division & WSRC & Westinghouse Savannah River Company \\
\hline & Headquarters, usually as a suffix to DOE & WW & Wash Water \\
\hline INMM & Integrated Nuclear Material Management & Y2K & Year 2000 (as in computer compliance) \\
\hline
\end{tabular}




\section{Appendix B - HLW System Priorities}

1. Maintain operating facilities in a safe and production-ready condition:

1a. Safeguard health and safety of workers and public

1b. Continue stewardship of current waste inventories

1c. Implement improvement programs/projects critical to $1 \mathrm{a}$ and $1 \mathrm{~b}$

2. Support critical Site missions (i.e., DNFSB 94-1):
2a. Operate Evaporators and Tank Farms as required to provide receipt space for Canyon waste

2b. Operate ETF to support Canyons, Tank Farms and Evaporators

3. Comply with the approved FFA Waste Removal Plan and Schedule (i.e., empty and close all old-style tanks by 2022)

4. Near-term compliance with the Site Treatment Plan (i.e., maintain an average production of 200 canisters per year in DWPF and process $50 \%$ of nonPUREX legacy wastes at CIF by $4 Q$ FY98):

4a. $\quad$ Provide DWPF materials and analytical support to produce 200 canisters per year

4b. Operate evaporators and Tank Farms to provide receipt space for DWPF recycle

4c. Operate ESP to provide Tank 51 (Batch 1A) sludge feed to DWPF

4d. Complete Tank 42 washing, qualification and transfer to Tank 51 to provide sludge feed (Batch 18 ) to DWPF

4e. Operate CIF to meet

4f. Prepare Tank 8 and Tank 40 sludges (Batch 2) feed to DWPF

4g. Develop a washing strategy to remove the Tank 42 heel

4h. Prepare Tank 40 equipment for sludge processing

4i. Start up the RHLWE to evaporate ESP wash water generated during Batch 2 processing

5. Mid-term strategy to support Canyon missions and DWPF production:
5a. Resolve DNFSB Recommendation 96-1 regarding ITP
5b. Resume Salt Processing
5c. Deploy Tank 42 as a Salt Processing feed tank
5d. Remove supernate and saltcake to create space in the Tank Farms
5e. Prepare sludge batches to maintain continuity of DWPF operations (Batch 3 , Tks 7, 11, 18, 19; Batch 4, Tks 4, 7, 12, 14)
5f. Install Tank 51 aluminum dissolution modifications

6. Long-term strategy to ensure continuity of DWPF operations, with both sludge and salt:
6a. Startup and operate Late Wash and the DWPF Salt Cell
6b. Demonstrate salt removal technology alternatives
6c. Continue saltcake removal
6d. Install aluminum dissolution equipment on Tank 40
6e. Continue sludge processing to maintain continuity of DWPF operations (Batch 5-9)

7. Develop new technologies that have a strong potential to reduce cost

8. Accelerate operation of the HLW System and thereby reduce program duration and life cycle cost

9. Develop and implement tank and facility closure methods

10. Perform engineering, technical and planning activities that reduce programmatic risk 


\section{Appendix C.1 - Funding (250 cans/yr)}

\begin{tabular}{|c|c|c|c|c|c|c|c|c|c|c|c|c|}
\hline Project Title & Project \# & FY98 & FY99 & FYOO & FY01 & FY02 & FY03 & FY04 & FY05 & EY06 & EY07 & FY08 \\
\hline H-Tank Farm & SR-HL01 & 93,734 & 94,806 & 90,253 & 91,975 & 94,999 & 97,934 & 101,166 & 104,505 & 107,943 & 111,495 & 115,165 \\
\hline F-Tank Farm & SR-HLO2 & 51,833 & 55,792 & 59,135 & 60,255 & 62,248 & 63,292 & 65,386 & 67,550 & 69,786 & 72,096 & 74,482 \\
\hline Waste Removal Operations & SR-HLO3 & 2,016 & 2,190 & 2,362 & 6,937 & 15,261 & 30,203 & 25,712 & 13,942 & 10,323 & 20,676 & 25,746 \\
\hline ITP/ESP & SR-HL04 & 85,531 & 64,242 & 72,563 & 87,353 & 97,091 & 95,129 & 105,661 & 125,202 & 117,724 & 137,036 & 140,775 \\
\hline Vitrification & SR-HL05 & 125,831 & 143,838 & 147,720 & 158,547 & 161,917 & 159,996 & 165,212 & 171,424 & 177,270 & 183,048 & 188,740 \\
\hline Glass Waste Storage & SR-HLOG & 517 & 526 & 821 & 12554 & 37503 & 44837 & 33074 & 652 & 673 & 1,126 & 1,162 \\
\hline Tank Farm Sevices I & SR-HLO9 & 3,333 & 320 & 0 & 0 & 0 & 0 & 0 & 0 & 0 & 0 & 0 \\
\hline Storm Water Upgrades & SR-HL10 & 1,253 & 4,329 & 6,382 & 0 & 0 & 0 & 0 & 0 & 0 & 0 & 0 \\
\hline Tank Farm Services II & SR-HL11 & 0 & 3,604 & 7,255 & 9,363 & 5,872 & 0 & 0 & 0 & 0 & 0 & 0 \\
\hline Waste Removal Project & $\underline{\text { SR-HL12 }}$ & $\underline{23,026}$ & $\underline{24,467}$ & $\underline{76,694}$ & $\underline{134,644}$ & 128,586 & $\underline{92,541}$ & $\underline{89,885}$ & $\underline{32,774}$ & $\underline{49,167}$ & $\underline{62,577}$ & $\underline{87,107}$ \\
\hline HLWMD Sub-Total & & 387,074 & 394,114 & 463,185 & 561,628 & 603,477 & 583,932 & 586,096 & 516,049 & 532,886 & 588,054 & 633,177 \\
\hline Effluent Treatment Facility & SR-HL07 & 17,353 & 16,920 & 18,853 & 18,156 & 19,255 & 19,534 & 20,341 & 20,956 & 21,567 & 22,272 & 23,000 \\
\hline Saltstone & SR-HL08 & 7,753 & 1,871 & 2,216 & 8,688 & 9,486 & 14,813 & 26,277 & 41,900 & 37,721 & 33,290 & 34,168 \\
\hline Consol. Incinerator Fac. & SR-SW01 & $\underline{22,168}$ & $\underline{22,875}$ & $\underline{24,310}$ & $\underline{25,020}$ & $\underline{26,745}$ & $\underline{24,618}$ & $\underline{25,046}$ & $\underline{26,177}$ & $\underline{27,442}$ & $\underline{28,320}$ & $\underline{29,225}$ \\
\hline Solid Waste Div. Sub-Tota & & 47,274 & 41,666 & 45,379 & 51,864 & 55,486 & 58,965 & 71,664 & 89,033 & 86,730 & 83,882 & 86,393 \\
\hline Grand Totals & & 434,348 & 435,780 & 508,564 & 613,492 & 658,963 & 642,897 & 657,760 & 605,082 & 619,616 & 671,936 & 719,570 \\
\hline
\end{tabular}




\section{Appendix C.1 - Funding (250 cans/yr)}

\begin{tabular}{|c|c|c|c|c|c|c|c|c|c|c|c|c|}
\hline Project Title & Project \# & FY09 & FY10 & FY11 & FY12 & FY13 & FY14 & FY15 & $\underline{F Y 16}$ & FY17 & FY18 & FY19 \\
\hline $\mathrm{H}$-Tank Farm & SR-HL01 & 99,384 & 82,556 & 85,275 & 77,484 & 69,151 & 71,430 & 73,785 & 58,530 & 36,240 & 18,782 & 0 \\
\hline F-Tank Farm & SR-HLO2 & 76,948 & 71,236 & 56,630 & 49,793 & 51,443 & 43,959 & 26,541 & 0 & 0 & 0 & 0 \\
\hline Waste Removal & SR-HLO3 & 37,321 & 48,214 & 32,977 & 49,410 & 30,431 & 78,600 & 56,169 & 83,523 & 76,256 & 87,613 & 51,806 \\
\hline ITP/ESP & SR-HLO4 & 141,380 & 135,928 & 142,251 & 148,399 & 164,728 & 157,106 & 149,412 & 156,188 & 138,203 & 0 & 0 \\
\hline Vitrification & SR-HL05 & 195,177 & 201,543 & 207,820 & 219,778 & 226,422 & 228,846 & 245,079 & 242,169 & 249,396 & 0 & 0 \\
\hline Glass Waste Storage & SR-HL06 & 1,200 & 1,239 & 1,279 & 1,321 & 1,363 & 1,408 & 3,510 & 3,626 & 3,745 & 3,869 & 3,996 \\
\hline Tank Farm Sevices I & SR-HL09 & 0 & 0 & 0 & 0 & 0 & 0 & 0 & 0 & 0 & 0 & 0 \\
\hline Storm Water Upgrades & SR-HL10 & 0 & 0 & 0 & 0 & 0 & 0 & 0 & 0 & 0 & 0 & 0 \\
\hline Tank Farm Services II & SR-HL11 & 0 & 0 & 0 & 0 & 0 & 0 & 0 & 0 & 0 & 0 & 0 \\
\hline Waste Removal & $\underline{\text { SR-HL12 }}$ & 102,480 & $\underline{96,888}$ & $\underline{78,641}$ & $\underline{51,746}$ & $\underline{56,022}$ & $\underline{42,057}$ & $\underline{21,072}$ & $\underline{18,113}$ & $\underline{16,419}$ & $\underline{23,161}$ & $\underline{9,227}$ \\
\hline HLWMD Sub-Total & & 653,890 & 637,604 & 604,873 & 597,931 & 599,560 & 623,406 & 575,568 & 562,149 & 520,259 & 133,425 & 65,029 \\
\hline Effluent Treatment Facility & SR-HLO7 & 23,753 & 24,530 & 25,332 & 26,161 & 27,017 & 27,902 & 28,815 & 29,758 & 30,732 & 31,739 & 8,195 \\
\hline Saltstone & SR-HL08 & 40,412 & 49,884 & 38,425 & 39,932 & 41,133 & 43,692 & 37,386 & 20,000 & 16,292 & 16,830 & 4,740 \\
\hline Consol. Incinerator Fac. & $\underline{\text { SR-SW01 }}$ & $\underline{30,160}$ & $\underline{31,125}$ & $\underline{32,122}$ & $\underline{33,150}$ & $\underline{34,212}$ & $\underline{35,308}$ & $\underline{36,439}$ & $\underline{37.607}$ & $\underline{38,813}$ & 40.058 & 41,343 \\
\hline Solid Waste Div. Sub-Tota & & 94,325 & 105,539 & 95,879 & 99,243 & 102,362 & 106,902 & 102,640 & 87,365 & 85,837 & 88,627 & 54,278 \\
\hline Grand Totals & & 748,215 & 743,143 & 700,752 & 697,174 & 701,922 & 730,308 & 678,208 & 649,514 & 606,096 & 222,052 & 119,307 \\
\hline
\end{tabular}




\section{Appendix C.1 - Funding (250 cans/yr)}

\begin{tabular}{|c|c|c|c|c|c|c|c|c|c|c|c|}
\hline Project Title & Project \# & FY20 & FY21 & FY22 & $\mathrm{FY} 23$ & FY24 & FY25 & FY26 & FY27 & FY28 & Total \\
\hline H-Tank Farm & SR-HL01 & 0 & 0 & 0 & 0 & 0 & 0 & 0 & 0 & 0 & $1,776,592$ \\
\hline F-Tank Farm & SR-HL02 & 0 & 0 & 0 & 0 & 0 & 0 & 0 & 0 & 0 & $1,078,405$ \\
\hline Waste Removal & SR-HL03 & 9,242 & 0 & 0 & 0 & 0 & 0 & 0 & 0 & 0 & 796,930 \\
\hline ITP/ESP & SR-HLO4 & 0 & 0 & 0 & 0 & 0 & 0 & 0 & 0 & 0 & $2,461,902$ \\
\hline Vitrification & SR-HL05 & 0 & 0 & 0 & 0 & 0 & 0 & 0 & 0 & 0 & $3,799,773$ \\
\hline Glass Waste Storage & SR-HLO6 & 4,126 & 4,260 & 3,250 & 3,355 & 3,464 & 3,576 & 0 & 0 & 0 & 182,032 \\
\hline Tank Farm Sevices I & SR-HLO9 & 0 & 0 & 0 & 0 & 0 & 0 & 0 & 0 & 0 & 3,653 \\
\hline Storm Water Upgrades & SR-HL10 & 0 & 0 & 0 & 0 & 0 & 0 & 0 & 0 & 0 & 11,964 \\
\hline Tank Farm Services II & SR-HL11 & 0 & 0 & 0 & 0 & 0 & 0 & 0 & 0 & 0 & 26,094 \\
\hline Waste Removal & $\underline{\text { SR-HL12 }}$ & $\underline{0}$ & $\underline{0}$ & $\underline{0}$ & $\underline{0}$ & $\underline{0}$ & $\underline{0}$ & $\underline{0}$ & $\underline{0}$ & $\underline{0}$ & $1,317,294$ \\
\hline HLWMD Sub-Total & & 13,368 & 4,260 & 3,250 & 3,355 & 3,464 & 3,576 & 0 & $\mathbf{0}$ & $\mathbf{0}$ & $11,454,639$ \\
\hline Effluent Treatment Facility & SR-HL07 & 0 & 0 & 0 & 0 & 0 & 0 & 0 & 0 & 0 & 502,141 \\
\hline Saltstone & SR-HL08 & 0 & 0 & 0 & 0 & 0 & 0 & 0 & 0 & 0 & 566,909 \\
\hline Consol. Incinerator Fac. & SR-SW01 & $\underline{42,670}$ & $\underline{44,040}$ & $\underline{45,455}$ & $\underline{46.915}$ & 48,422 & 49,978 & $\underline{51,585}$ & $\underline{53,244}$ & $\underline{54,948}$ & \\
\hline Solid Waste Div. Sub-Tot & & 42,670 & 44,040 & 45,455 & 46,915 & 48,422 & 49,978 & 51,585 & 53,244 & 54,948 & $2,178,590$ \\
\hline Grand Totals & & 56,038 & 48,300 & 48,705 & 50,270 & 51,886 & 53,554 & 51,585 & 53,244 & 54,948 & $13,633,229$ \\
\hline
\end{tabular}




\section{Appendix C.2 - Funding Comparison ( 250 cans/yr vs. 200 cans/yr)}

\begin{tabular}{|c|c|c|c|c|c|c|c|c|c|c|c|}
\hline Total Costs & FY98 & FY99 & FYOO & FY01 & FY02 & FY03 & FY04 & FY05 & FY06 & FY07 & FY08 \\
\hline 250 cans/yr & 434,348 & 435,780 & 508,564 & 613,492 & 658,963 & 642,897 & 657,760 & 605,082 & 619,616 & 671,936 & 719,570 \\
\hline 200 cans/yr & $\underline{434,348}$ & 431,573 & 447,232 & $\underline{576,165}$ & $\underline{630,899}$ & $\underline{613,119}$ & 663,395 & 622,222 & $\underline{661,750}$ & $\underline{651,170}$ & $\underline{648,380}$ \\
\hline \multirow[t]{2}{*}{ Delta } & 0 & 4,207 & 61,332 & 37,327 & 28,064 & 29,778 & $-5,635$ & $-17,140$ & $-42,134$ & 20,766 & 71,190 \\
\hline & FY09 & FY10 & FY11 & FY12 & FY13 & FY14 & FY15 & FY16 & FY17 & FY18 & FY19 \\
\hline 250 cans/yr & 748,215 & 743,143 & 700,752 & 697,174 & 701,922 & 730,308 & 678,208 & 649,514 & 606,096 & 222,052 & 119,307 \\
\hline 200 cans/yr & $\underline{702,292}$ & 769,499 & $\underline{778,406}$ & $\underline{770,149}$ & $\underline{719,427}$ & 716,817 & $\underline{722,686}$ & $\underline{716,532}$ & 709,134 & $\underline{750,035}$ & $\underline{747,984}$ \\
\hline \multirow[t]{2}{*}{ Delta } & 45,923 & $-26,356$ & $-77,654$ & $-72,975$ & $-17,505$ & 13,491 & $-44,478$ & $-67,018$ & $-103,038$ & $-527,983$ & $-628,677$ \\
\hline & FY20 & FY21 & FY22 & FY23 & FY24 & FY25 & FY26 & FY27 & FY28 & \multicolumn{2}{|c|}{ Grand Totals } \\
\hline 250 cans/yr & 56,038 & 48,300 & 48,705 & 50,270 & 51,886 & 53,554 & 51,585 & 53,244 & 54,948 & \multicolumn{2}{|r|}{$13,633,229$} \\
\hline 200 cans/yr & $\underline{709,621}$ & 639,422 & $\underline{596,990}$ & $\underline{363,987}$ & 405,584 & $\underline{63,182}$ & $\underline{51,585}$ & $\underline{53,244}$ & $\underline{54,948}$ & \multicolumn{2}{|r|}{$17,421,777$} \\
\hline Delta & $-653,583$ & $-591,122$ & $-548,285$ & $-313,717$ & $-353,698$ & $-9,628$ & 0 & 0 & 0 & \multicolumn{2}{|r|}{$-3,788,548$} \\
\hline
\end{tabular}

Summary: Although the 250 canister/year case requires additional funding in the first five years (FY99-FY03), the 250 canister/year case requires less annual funding thereafter. The 250 canister/year case breaks even with the 200 canister/year case in FY13 and completes the program with $\$ 3.7$ Billion in life cycle cost savings. 


\section{Appendix D - HLW Projects}

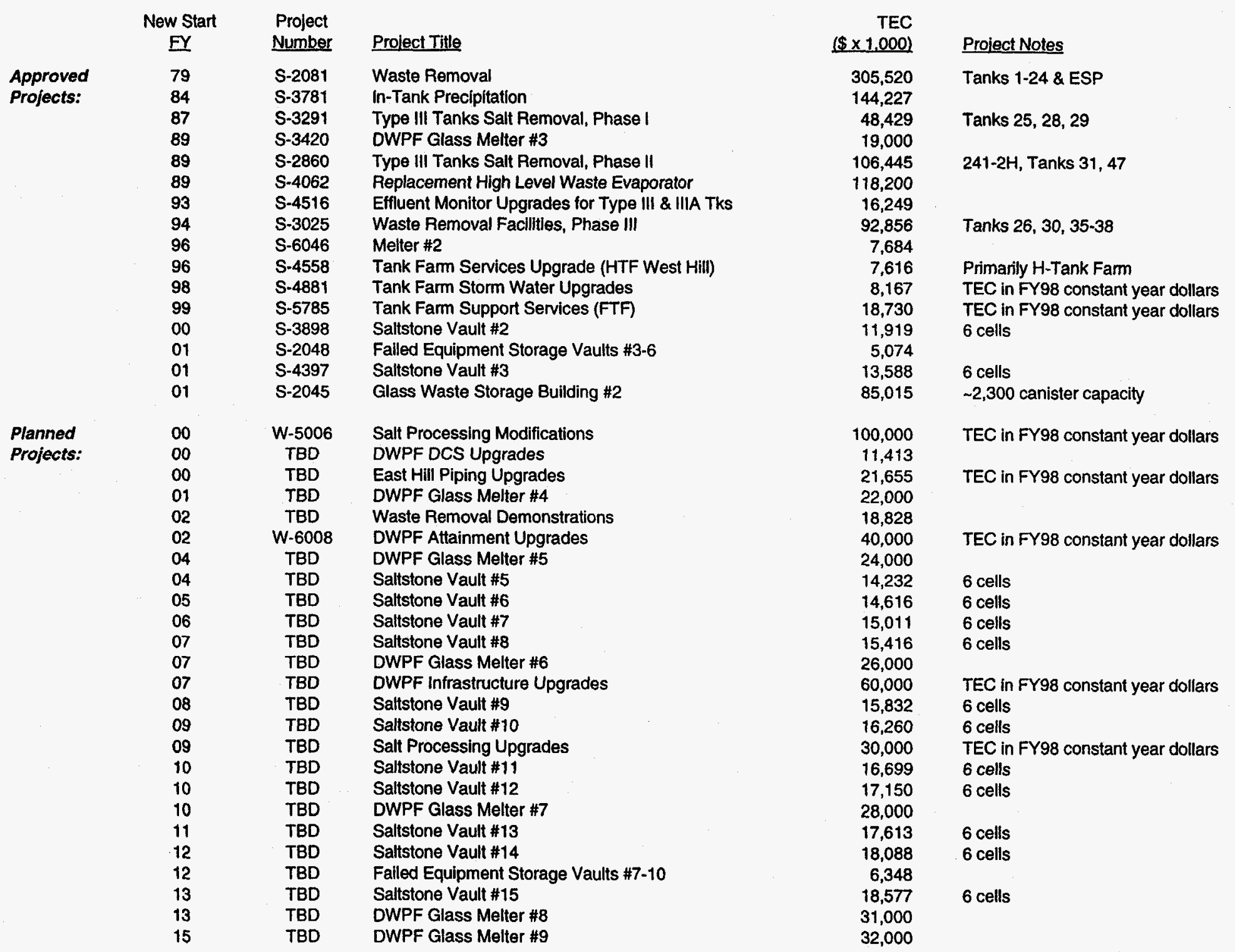

Notes: Only projects with TEC $>\$ 5,000,000$ are shown. "Planned Projects" do not have detailed estimates or scopes; estimates shown are placeholders in the outyear budget. 


\section{Appendix E.1 - Approved FFA Waste Removal Plan \& Schedule}

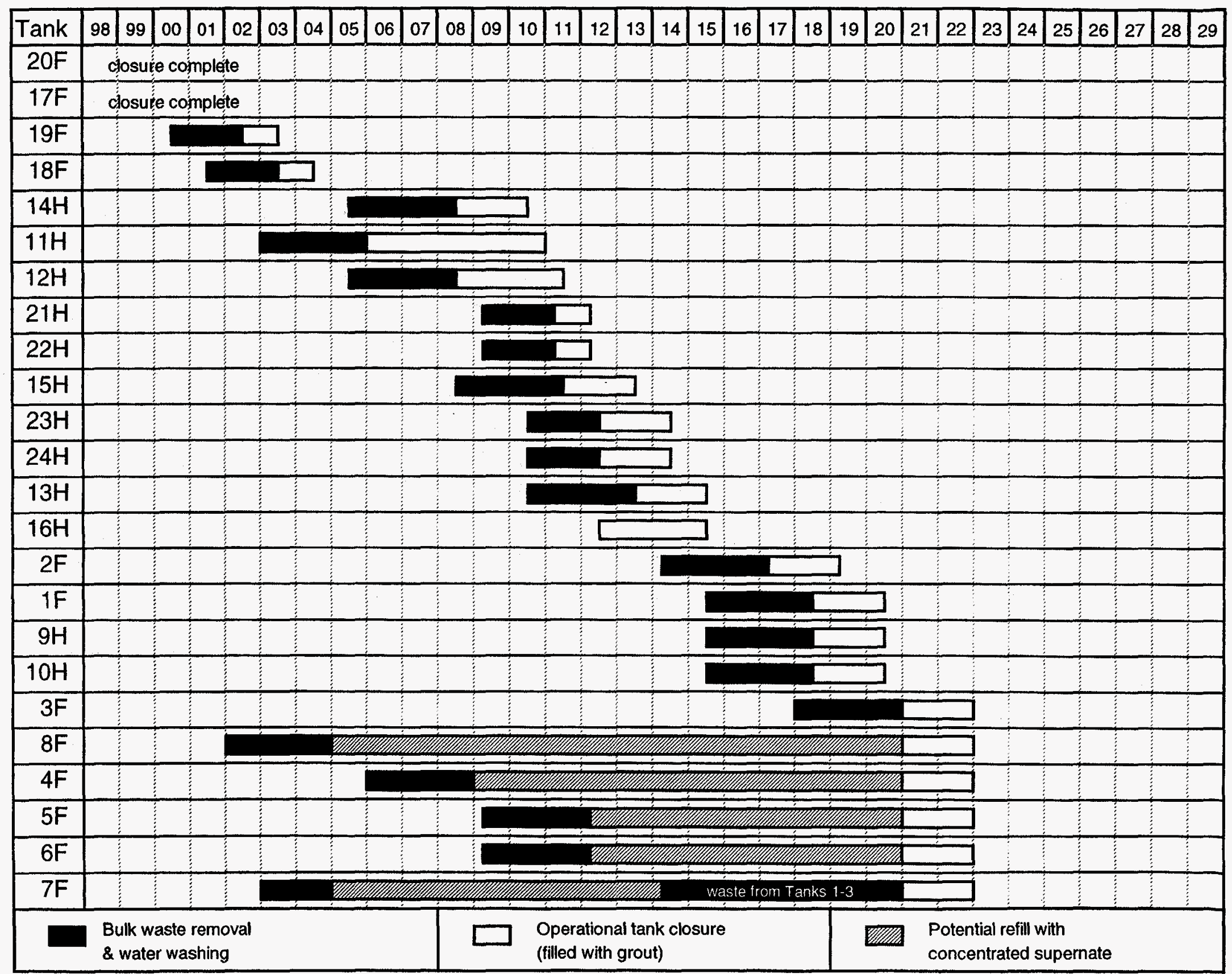

E.1 - 1 


\section{Appendix E.2 - Planned Waste Removal Schedule}

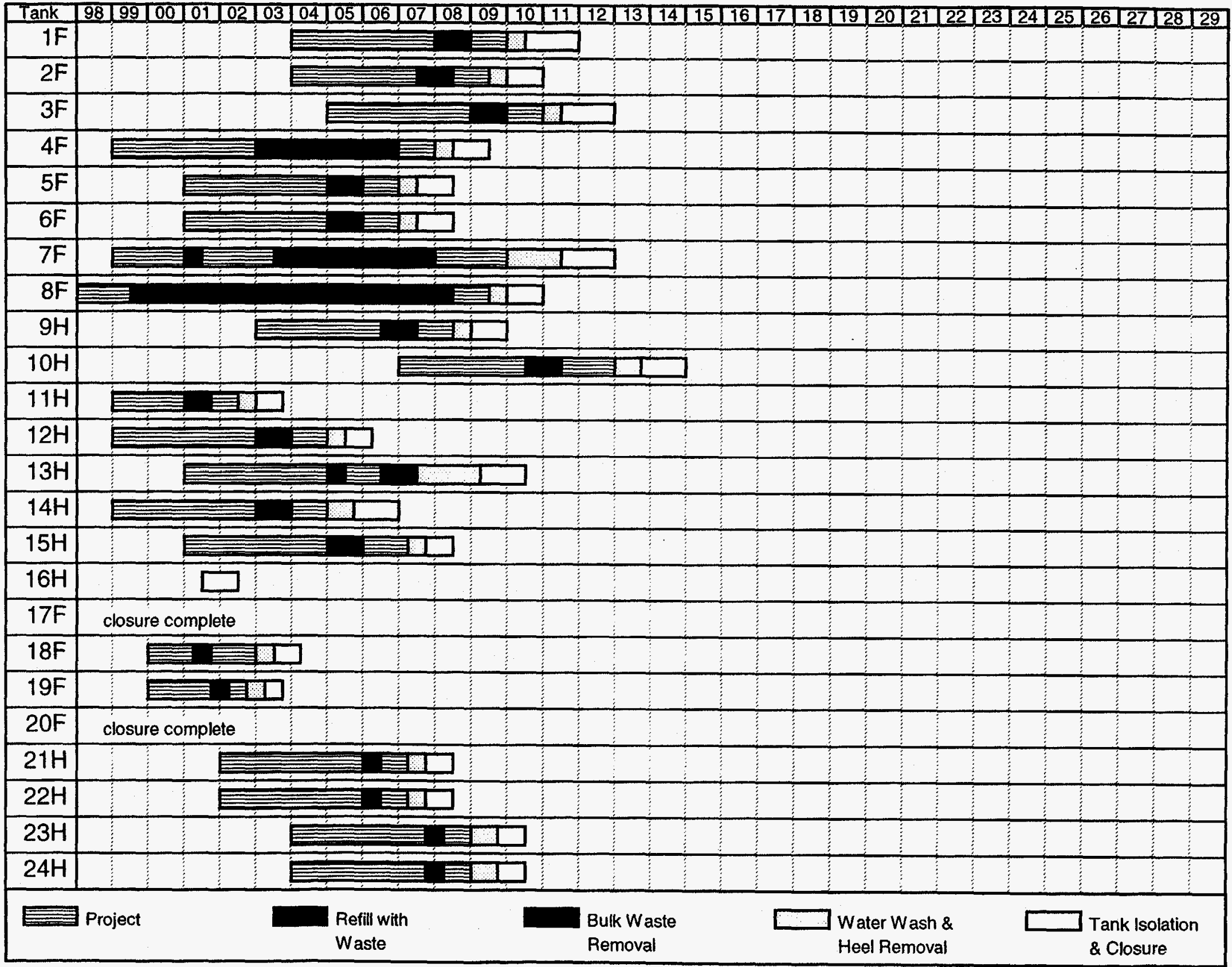

E.2 - 1 


\section{Appendix E.2 - Planned Waste Removal Schedule}

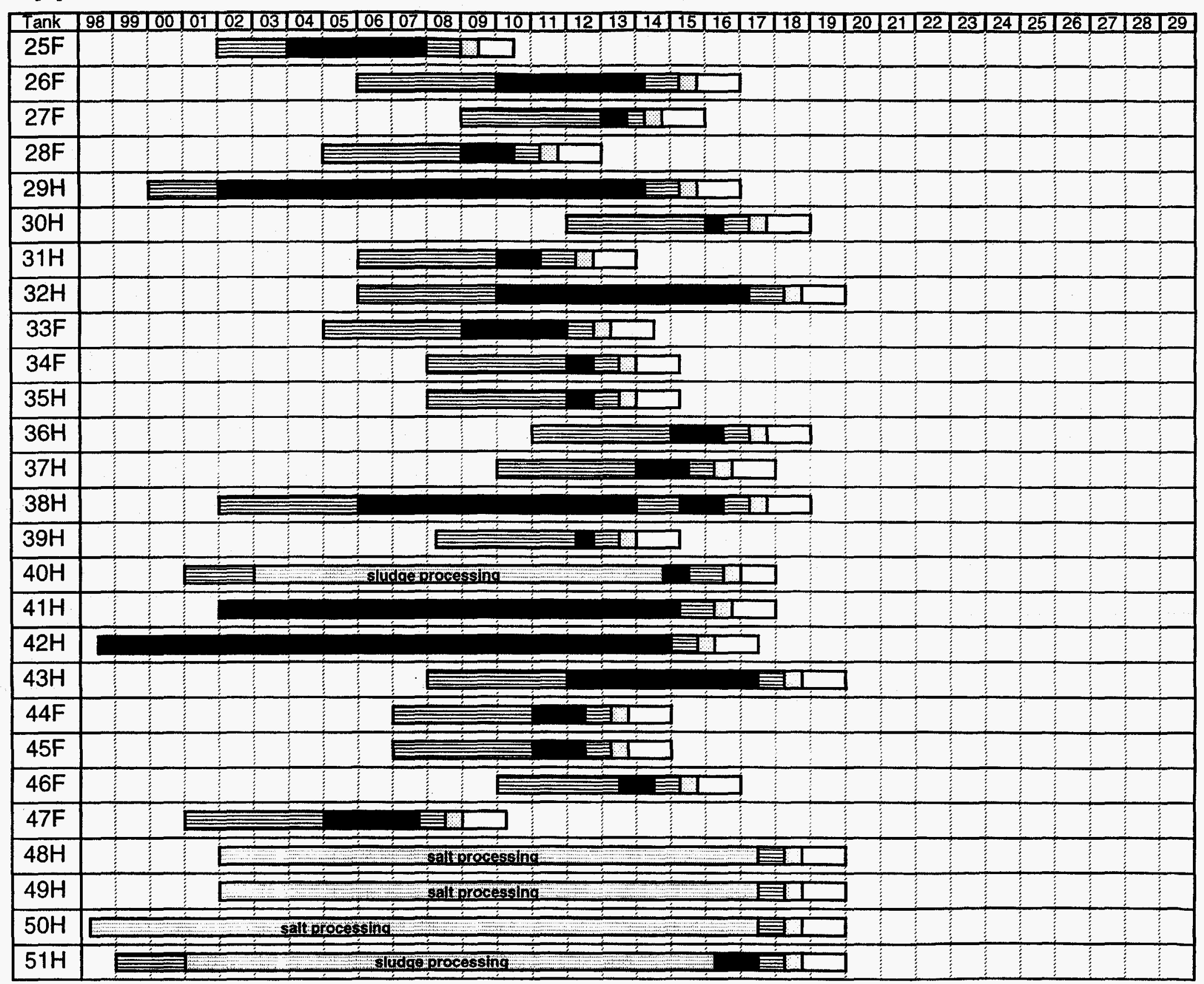

E.2 - 2 


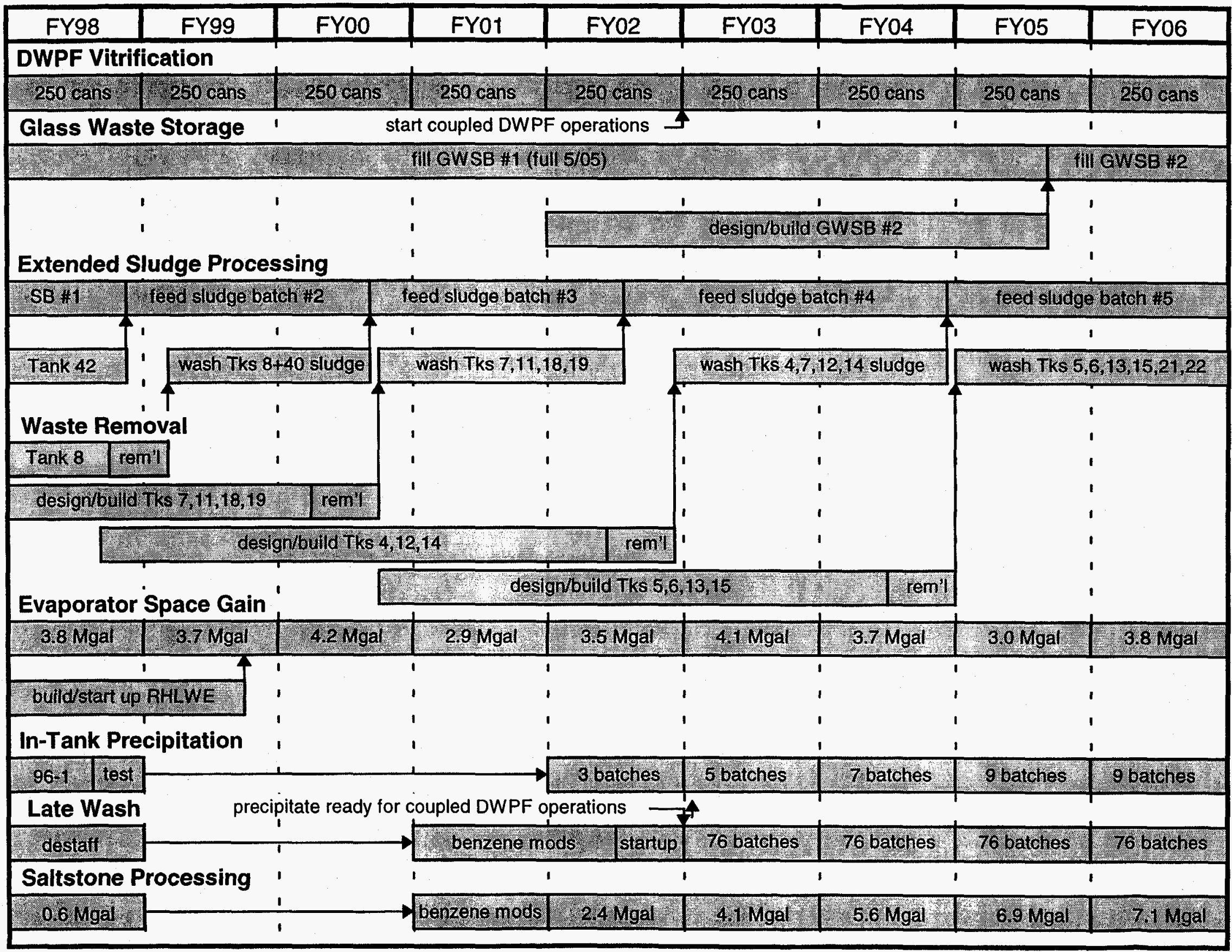

$F-1$ 


\section{Appendix G.1 - Tank Farm Material Balance ( 250 cans/yr)}

\begin{tabular}{|c|c|c|c|c|c|c|c|c|c|c|c|c|c|c|c|c|c|c|}
\hline \multirow{2}{*}{$\begin{array}{l}\text { End of } \\
\text { Morrr }\end{array}$} & \multicolumn{7}{|c|}{ Influents } & \multicolumn{4}{|c|}{ Backlog } & \multicolumn{5}{|c|}{ Effluents } & \multirow{2}{*}{$\begin{array}{c}\text { Usable } \\
\text { Space }\end{array}$} & \multirow[b]{2}{*}{ Notes } \\
\hline & F-LHW & F.HHW & H-LHW & $\mathrm{H}-\mathrm{HHW}$ & DWPF & ESPI & Tank WW & $T \mathrm{k}$ & Volume & SGF & Ev & 2F Evap & 2H Evap & RHLWE & ITP & Other & & \\
\hline Nov-97 & & & & & & & & & & & & & & & & & $1,172,340$ & actual end of Nov inventory \\
\hline Dec-97 & 12,993 & 0 & 3,030 & of & 190,003 & of & 0 & 33 & 351,000 & 0.71 & $2 \mathrm{~F}$ & 249,210 & 173,154 & of & of & 0 & $1,388,678$ & \\
\hline Jan-98 & 20,000 & 500 & 7,360 & 0 & 190,003 & of & 의 & & & & & of & 176,228 & of & 이 & 0 & $1,347,043$ & \\
\hline Feb-98 & 10,500 & 500 & 4,500 & 0 & 190,003 & of & 0 & & & & & of & 174,198 & of & 0 & 0 & $1,315,738$ & \\
\hline Mar-98 & 15,500 & 500 & 12,500 & 요 & 190,003 & of & 0 & 42 & 182,520 & 0.99 & $2 \mathrm{H}$ & 0 & 360,573 & 0 & 0 & 0 & $1,457,808$ & \\
\hline Apr-98 & 38,500 & 500 & 8,500 & 0 & 190,003 & 의 & 0 & & & & & 0 & 177,038 & 0 & 이 & 0 & $1,397,342$ & \\
\hline May-98 & 40,500 & 8,500 & 42,000 & 0 & 190,003 & 0 & 0 & 33 & 95,000 & 0.71 & $2 F$ & 67,450 & 200,823 & of & of & 0 & $1,384,612$ & \\
\hline Jun-98 & 49,500 & 8,500 & 33,250 & 요 & 190,003 & of & 의 & 32 & 421,000 & 0.68 & $2 F$ & 286,280 & 194,610 & 0 & 0] & 356,730 & $1,940,979$ & Other is Tk 42 sludge to Tk 51 \\
\hline Jul-98 & 10,500 & 500 & 13,250 & 0 & 190,003 & of & 0 & 32 & 351,000 & 0.68 & $2 F$ & 238,680 & 180,410 & 0 & 이 & 0 & $2,145,816$ & \\
\hline Aug.98 & 22,500 & 500 & 13,250 & 아 & 190,003 & of & 0 & 33 & 140,000 & 0.71 & $2 \mathrm{~F}$ & 99,400 & 180,410 & of & of & 讨 & $2,199,374$ & \\
\hline Sep-98 & 22,500 & 500 & 13,250 & 이 & 190,003 & 이 & 0 & & & & & 0) & 180,410 & of & 이 & 0 & $2,153,531$ & \\
\hline FY98 & 242,993 & 20,500 & 150,890 & 이 & $1,900,030$ & 0] & 0 & & $1,540,520$ & & & 941,020 & $1,997,854$ & 이 & 01 & 356,730 & & \\
\hline Oct-98 & 22,500 & 500 & 13,250 & 14,000 & 186,497 & 요 & 0 & 32 & 175,500 & 0.68 & $2 F$ & 119,340 & 167,847 & of & of & 의 & $2,203,971$ & \\
\hline Nov-98 & 15,500 & 500 & 13,250 & 14,000 & 186,497 & of & 의 & & & & & of & 167,847 & of & 0 & 0 & $2,142,071$ & \\
\hline Dec-98 & 34,500 & 3,500 & 13,250 & 14,000 & 186,497 & 의 & 의 & & & & & o & 167,847 & of & ㅇ. & 0 & $2,058,172$ & \\
\hline Jan-99 & 10,500 & 500 & 10,000 & 14,000 & 186,497 & 127,413 & 0 & $32 \uparrow 35$ & 421,200 & 0.64 & $2 \mathrm{~F}$ & 308,556 & 237.160 & 0 & 0 & 0 & $2,254,978$ & \\
\hline Feb-99 & 22,500 & 500 & 10,000 & 14,000 & 186,497 & 127,413 & 0 & 33 & 145,000 & 0.71 & $2 \mathrm{~F}$ & 141,938 & 237,160 & of & 0 & 0 & $2,273,166$ & \\
\hline Mar-99 & 10,500 & 500 & 10,000 & 14,000 & 186,497 & 127,413 & 0 & & & & & 38,988 & 237,160 & 0 & 이 & 0 & $2,200,405$ & \\
\hline Apr-99 & 22,500 & 500 & 10,000 & 14,000 & 186,497 & 127,413 & 요 & & & & & 38,988 & 237,160 & of & 0 & $-1,070,620$ & $1,045,023$ & Tk 40 to ESP use, $-1,007.62 \mathrm{kga}$ \\
\hline May-99 & 10,500 & 500 & 10,000 & 14,000 & 186,497 & 127,413 & 의 & & & & & 38,988 & 237,160 & of & 0) & 의 & 972,261 & \\
\hline Jun-99 & 22,500 & 500 & 10,000 & 14,000 & 186,497 & 127.413 & 의 & & & & & 38,988 & 237,160 & of & 요 & 0 & 887,500 & \\
\hline Jul-99 & 10,500 & 500 & 10,000 & 14,000 & 186,497 & 127,413 & 의 & 30 & 150,000 & 0.31 & $\mathrm{RE}$ & 38,988 & 125,885 & 157,774 & 0 & 의 & 861,238 & RE startup 6/30/99 \\
\hline Aug-99 & 22,500 & 500 & 10,000 & 14,000 & 186,497 & 127,413 & 의 & 30 & 250,000 & 0.31 & $\mathrm{RE}$ & 38,988 & 125,885 & 188,774 & 요 & 0 & 853,976 & \\
\hline Sep-99 & 10,500 & 500 & 10,000 & 14,000 & 186.497 & 127,413 & 0 & 30 & 300,000 & 0.31 & $\mathrm{RE}$ & 38,988 & 125,885 & 204,274 & 0 & 0 & 874,215 & \\
\hline FY99 & 215,000 & 9,000 & 129,750 & 168,000 & $2,237,964$ & $1,146,717$ & 0 & & $1,441,700$ & & & 842,753 & $2,304,158$ & 550,823 & a & $-1,070,620$ & & \\
\hline Oct-99 & 22,500 & 500 & 10,000 & 14,000 & 186,497 & 127,143 & 의 & 30 & 388,000 & \begin{tabular}{|l|l}
0.31 \\
\end{tabular} & $\mathrm{RE}$ & 38,906 & 125,885 & 231,408 & 의 & 0 & 909,774 & \\
\hline Nov-99 & 10,500 & 500 & 10,000 & 14,000 & 186,497 & 127,143 & 0 & 39 & 200,000 & 0.56 & $2 F$ & 150,906 & 125,885 & 111,128 & 0 & 0 & 949,052 & \\
\hline Dec-99 & 22,500 & 500 & 10,000 & 14,000 & 186,497 & 127,143 & 의 & $32+35$ & 200,000 & 0.64 & RE & 38,906 & 125,885 & 239,128 & of & 0 & 992,331 & \\
\hline Jan-00 & 10,500 & 500 & 10,000 & 14,000 & 186,497 & 127,143 & 의 & $32+35$ & 200,000 & 0.64 & $\mathrm{RE}$ & 38,906 & 125,885 & 239,128 & 0 & 0 & $1,047,610$ & \\
\hline Feb-00 & 22,500 & 500 & 10,000 & 14,000 & 186.497 & 127,143 & 0 & 42 & 200,000 & 0.45 & $\mathrm{RE}$ & 38,906 & 125,885 & 201,128 & 요 & 0 & $1,052,889$ & \\
\hline Mar-00 & 10,500 & 500 & 10,000 & 14,000 & 186,497 & 요 & 0 & 39 & 200,000 & 0.56 & $2 F$ & 112,000 & 125,885 & 41,962 & of & 0 & $1,111,239$ & \\
\hline Apr-00 & 20,000 & 2,000 & 10,000 & 14,000 & 186,497 & 70,000 & 0 & 39 & 200,000 & 0.56 & $2 F$ & 133,420 & 125,885 & 80,042 & 0 & 0 & $1,148,090$ & \\
\hline May-00 & 20,000 & 2,000 & 10,000 & 14,000 & 186,497 & 70,000 & 의 & & & & & 21,420 & 125,885 & 80,042 & 0 & 0 & $1,072,940$ & \\
\hline Jun-00 & 20,000 & 2,000 & 10,000 & 14,000 & 186,497 & 70,000 & 요 & 39 & 200,000 & 0.56 & $2 F$ & 133,420 & 125,885 & 80,042 & o & 0 & $1,109,790$ & \\
\hline Jul-00 & 20,000 & 2,000 & 10,000 & 15,000 & 186,497 & 70,000 & 의 & 33 & 300,000 & 0.71 & $2 \mathrm{~F}$ & 234,420 & 125,885 & 80,042 & of & 의 & $1,246,641$ & \\
\hline Aug-00 & 20,000 & 2,000 & 10,000 & 15,000 & 186.497 & 70,000 & 의 & 39 & 200,000 & 0.56 & $2 \mathrm{~F}$ & 133,420 & 125,885 & 80,042 & 0 & 의 & $1,282,491$ & \\
\hline Sep-00 & 10,000 & 요 & 10,000 & 15,000 & 186,497 & 70,000 & 0 & & & & & 21,420 & 125,885 & 80,042 & 의 & 0 & $1,218,341$ & \\
\hline FYOO & 209,000 & 13,000 & 120,000 & 171,000 & $2,237,964$ & $1,055,715$ & 0 & & $2,288,000$ & & & $1,096,049$ & $1,510,626$ & $1,544,131$ & of & 0 & & \\
\hline
\end{tabular}




\section{Appendix G.1 - Tank Farm Material Balance ( 250 cans/yr)}

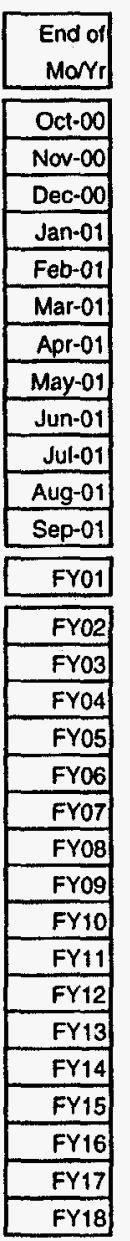

\begin{tabular}{|c|c|c|c|c|c|c|}
\hline \multicolumn{7}{|c|}{ Inffiuents } \\
\hline$F-L H W$ & F.HHW & H-LHW & $\mathrm{H}-\mathrm{HHW}$ & DWPF & ESPI & Tank $W W$ \\
\hline 10,000 & 0 & 10,000 & 15,000 & 186,497 & 70,000 & 0 \\
\hline 10,000 & 0 & 10,000 & 15,000 & 186,497 & 70,000 & \\
\hline 10,000 & 0 & 10,000 & 15,000 & 186,497 & 70,000 & ( \\
\hline 10,000 & 0 & 10,000 & 0 & 186,497 & 70,000 & 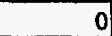 \\
\hline 10,000 & 0 & 10,000 & 0 & 186,497 & 70,000 & ( \\
\hline 10,000 & 0 & 10,000 & 0 & 186,497 & 70,000 & c \\
\hline 10,000 & 0 & 10,000 & o & 186,497 & 70,000 & 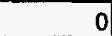 \\
\hline 10,000 & of & 10,000 & of & 186,497 & 70,000 & 0 \\
\hline 10,000 & 0 & 10,000 & 0 & 186,497 & 70,000 & 0 \\
\hline 10,000 & 0 & 10,000 & 0 & 186,497 & 70,000 & 0 \\
\hline 10,000 & 0 & 10,000 & 0 & 186,497 & 70,000 & \\
\hline 10,000 & 0 & 10,000 & 이 & 186,497 & 70,000 & 140,000 \\
\hline 120,000 & 0 & 120,000 & 45,000 & $2,237,964$ & 840,000 & 170, \\
\hline 120,000 & 0 & 120,000 & 0 & $3,116,313$ & 615,000 & 140,000 \\
\hline 120,000 & 0 & 120,000 & 0 & $3,116,313$ & $1,170,000$ & 190,000 \\
\hline 120,000 & 0 & 120,000 & 0 & $3,116,313$ & 975,000 & \\
\hline 120,000 & 0 & 120,000 & 0 & $3,116,313$ & 900,000 & 330,000 \\
\hline 120,000 & 0 & 120,000 & 0 & $3,116,313$ & 900,000 & 190,000 \\
\hline 120,000 & 0 & 120,000 & 0 & $3,116,313$ & $1,500,000$ & 750,000 \\
\hline 120,000 & 0 & 120,000 & 0 & $3,116,313$ & $1,500,000$ & 470,000 \\
\hline 120,000 & 0 & 120,000 & of & $3,116,313$ & $1,525,000$ & 520,000 \\
\hline 120,000 & 0 & 120,000 & 0 & $3,116,313$ & $1,525,000$ & 470,000 \\
\hline 120,000 & 0 & 120,000 & 0 & $3,116,313$ & 795,000 & 420,000 \\
\hline 120,000 & 0 & 120,000 & 이 & $3,116,313$ & 795,000 & 420,000 \\
\hline 120,000 & 0 & 120,000 & 0 & $3,116,313$ & 90,000 & 140,000 \\
\hline 120,000 & 0 & 120,000 & 0 & $3,116,313$ & 270,000 & 140,000 \\
\hline 120,000 & 0 & 120,000 & 0 & $3,116,313$ & 180,000 & 420,000 \\
\hline 120,000 & 0 & 120,000 & 0 & $3,116,313$ & o. & 420,000 \\
\hline 120,000 & 0 & 120,000 & 0 & $1,047,081$ & 0 & 140,000 \\
\hline of & 0 & 0 & 0 & 이 & o) & 420,000 \\
\hline
\end{tabular}

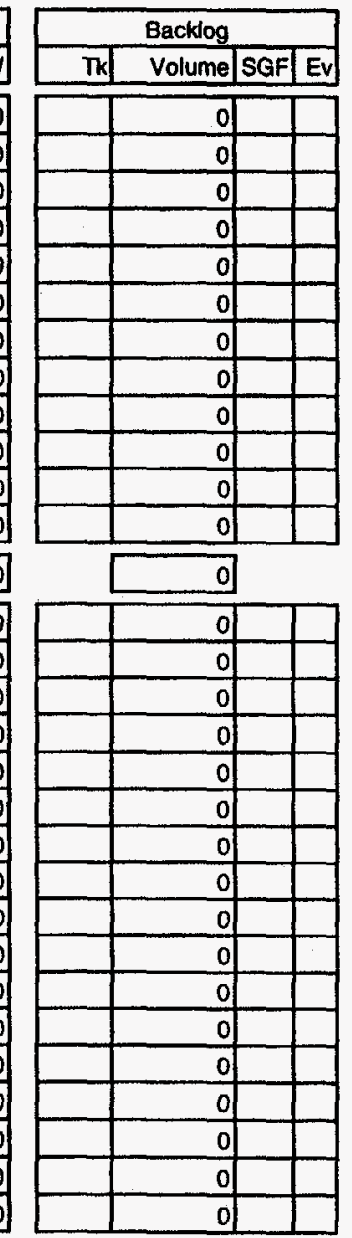

\begin{tabular}{|r|r|r|r|r|}
\hline \multicolumn{5}{|c|}{ Eftluents } \\
\hline 2F Evap & 2H Evap & RHLWE & ITP & Other \\
\hline 21,420 & 83,924 & 122,004 & 0 & 0 \\
\hline 21,420 & 83,924 & 122,004 & 0 & 0 \\
\hline 21,420 & 83,924 & 122,004 & 0 & 0 \\
\hline 21,420 & 83,924 & 122,004 & 0 & 250,000 \\
\hline 21,420 & 83,924 & 122,004 & 0 & 0 \\
\hline 21,420 & 83,924 & 122,004 & 0 & 0 \\
\hline 21,420 & 83,924 & 122,004 & 0 & 0 \\
\hline 21,420 & 83,924 & 122,004 & 0 & 300,000 \\
\hline 21,420 & 83,924 & 122,004 & 0 & 0 \\
\hline 21,420 & 83,924 & 122,004 & 0 & 0 \\
\hline 21,420 & 83,924 & 122,004 & 0 & 0 \\
\hline 75,706 & 83,924 & 200,718 & 0 & 200,000 \\
\hline 311,326 & $1,007,084$ & $1,542,758$ & 0 & 750,000 \\
\hline 327,676 & $1,402,341$ & $1,815,615$ & 698,000 & 350,000 \\
\hline 516,893 & $1,402,341$ & $2,145,647$ & 926,000 & 400,000 \\
\hline 383,550 & $1,402,341$ & $1,932,741$ & $1,349,000$ & \\
\hline 488,559 & $1,402,341$ & $2,077,482$ & $2,553,000$ & \\
\hline 434,273 & $1,402,341$ & $1,998,767$ & $1,214,000$ & \\
\hline 835,016 & $1,402,341$ & $2,640,025$ & $1,767,000$ & \\
\hline 726,445 & $1,402,341$ & $2,482,596$ & $1,683,000$ & \\
\hline 753,483 & $1,402,341$ & $2,524,308$ & $2,135,000$ & 0 \\
\hline 734,095 & $1,402,341$ & $2,496,196$ & $2,183,000$ & 0 \\
\hline 491,327 & $1,402,341$ & $2,070,964$ & $1,594,000$ & 0 \\
\hline 491,327 & $1,402,341$ & $2,070,964$ & $1,411,000$ & 0 \\
\hline 167,026 & $1,402,341$ & $1,530,015$ & $2,402,000$ & 0 \\
\hline 222,106 & $1,402,341$ & $1,627,935$ & $2,434,000$ & 0 \\
\hline 303,137 & $1,402,341$ & $1,736,404$ & $2,225,000$ & 0 \\
\hline 248,057 & $1,402,341$ & $1,638,484$ & $2,060,000$ & 0 \\
\hline 139,486 & 471,186 & 549,901 & & 0 \\
\hline 162,857 & 0 & 236,143 & & 0 \\
\hline & & & & \\
\hline
\end{tabular}
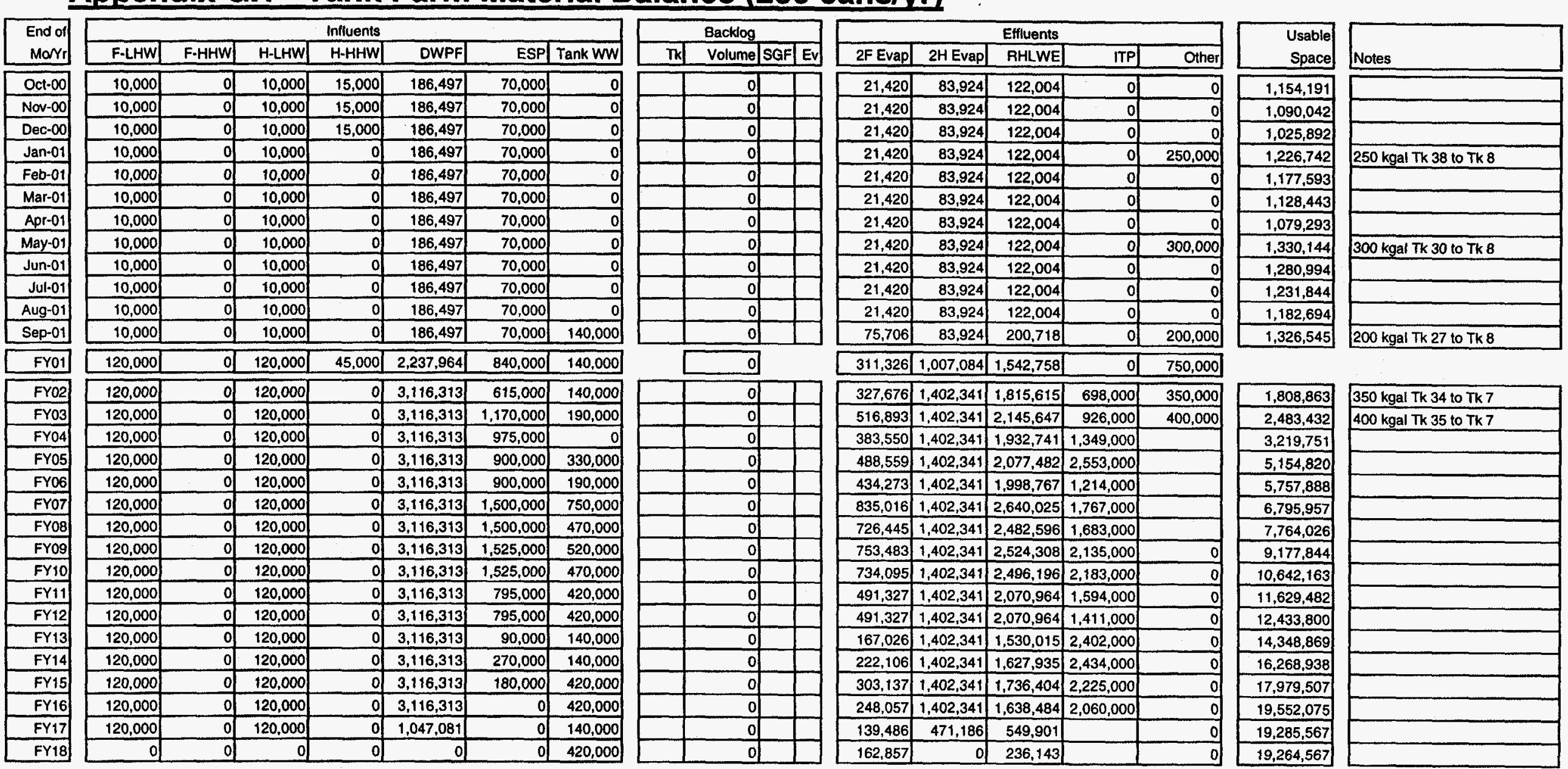


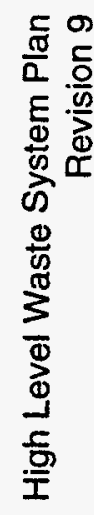

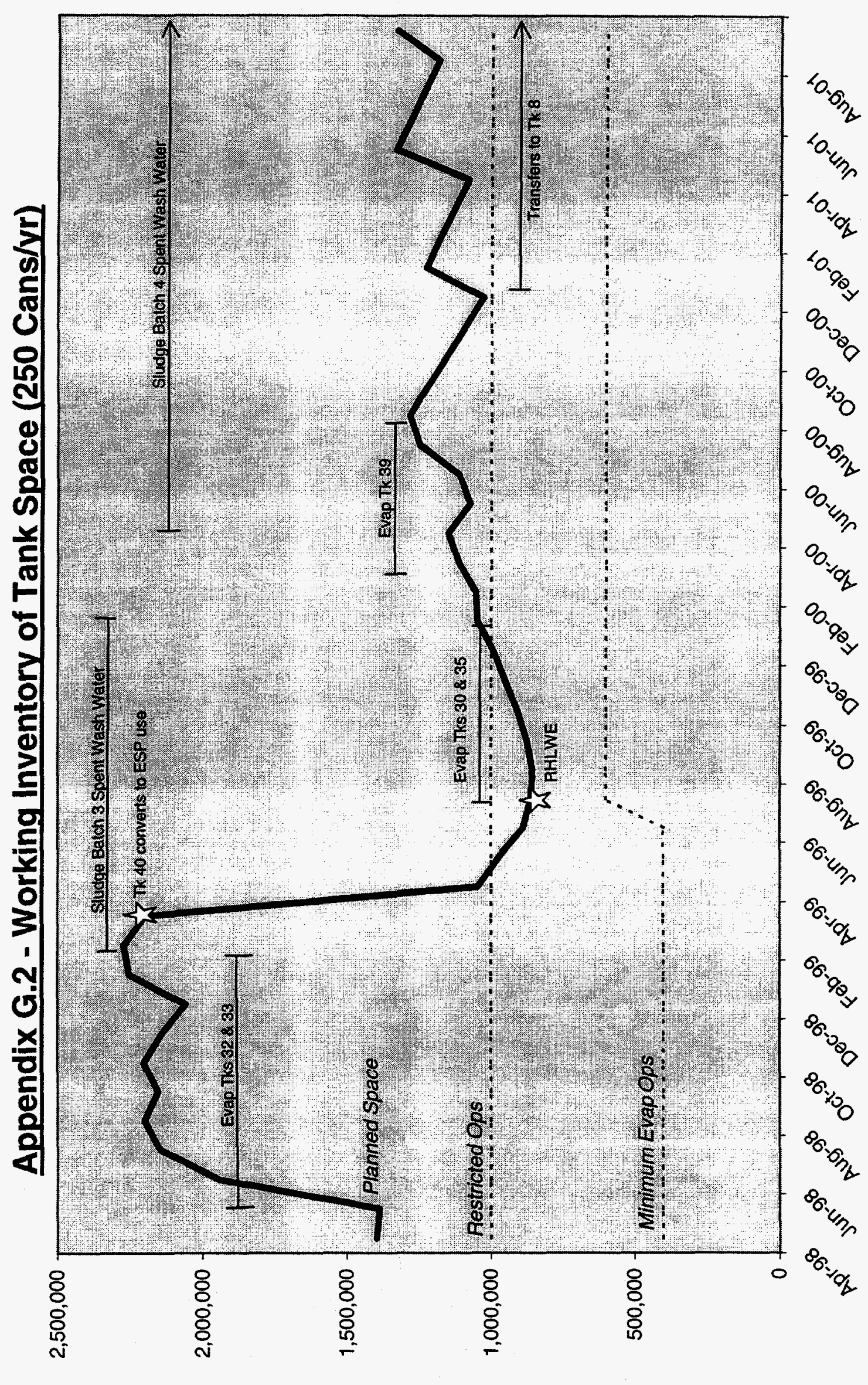

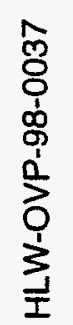


Appendix G.3 - Salt Processing ( 250 cans/yr)

\begin{tabular}{|c|c|c|c|c|c|c|c|c|c|c|c|c|c|c|c|c|}
\hline \multicolumn{11}{|c|}{ W-TANK PRECIPITATION FACIIITY OR REPLACEMENT PROCESS } & \multicolumn{3}{|c|}{ SALT SOLUTION PAODUCED } & \multicolumn{3}{|c|}{ SALTSTOME FACILTY } \\
\hline $\begin{array}{l}\text { Cycled } \\
\text { Bateh }\end{array}$ & $\begin{array}{l}\text { Stan } \\
\text { Date }\end{array}$ & $\begin{array}{c}\text { Duration } \\
\text { (Days) } \\
\end{array}$ & $\begin{array}{c}\text { Source } \\
\text { Tank } \\
\end{array}$ & $\begin{array}{r}\text { Waste } \\
\text { Removed } \\
\text { (Kgal) } \\
\end{array}$ & $\begin{array}{l}\text { Feed } \\
\text { Type }\end{array}$ & $\begin{array}{l}\text { Feed } \\
\text { lolTP } \\
\text { (Kgal) } \\
\end{array}$ & $\begin{array}{l}10 \text { w\% ppt } \\
\text { in Tank 48 } \\
(\text { Kgal) }\end{array}$ & $\begin{array}{l}\text { Pptcs } \\
\text { Conc } \\
\text { (CVGal) } \\
\end{array}$ & $\begin{array}{r}\begin{array}{c}\text { Ppt Fed to } \\
\text { Late Wash } \\
\text { (Kgal) }\end{array} \\
\end{array}$ & 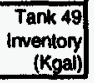 & $\begin{array}{c}\text { ITP Filtrate } \\
\text { (Kgal) }\end{array}$ & $\begin{array}{l}\text { ETF Conc } \\
\quad \text { (Kgal) } \\
\end{array}$ & $\begin{array}{c}\text { Tota } \\
\text { (Koal) }\end{array}$ & $\begin{array}{r}\text { Grout } \\
\text { Produced } \\
\text { (Kgal) }\end{array}$ & $\begin{array}{l}\text { Cum Vault } \\
\text { Cells Filled } \\
\text { (Each) }\end{array}$ & Notes: \\
\hline $\begin{array}{l}\text { FYG6 } \\
\text { C1/B1 }\end{array}$ & 9/2/95 & 128 & $\begin{array}{l}48 \\
38\end{array}$ & $\begin{array}{l}252 \\
130\end{array}$ & $\begin{array}{l}\text { supr } \\
\text { supr } \\
\text { stob } \\
\text { total: }\end{array}$ & $\begin{array}{r}252 \\
130 \\
30 \\
412\end{array}$ & 105 & 10 & 0 & of & 345 & 63 & 408] & 722 & 2.91 & 2.50 cells filled at stant \\
\hline CLFL Outage & 1/8/96 & 267 & & & & & 105 & 10 & 0 & 0 & 0 & 132 & 132 & 233 & 3.04 & \\
\hline FY96 totals & & & space gain & 382 & & 412 & 105 & 10 & 0 & o & & & & & & \\
\hline $\begin{array}{c}\text { FY97 } \\
\text { CLFL Outage }\end{array}$ & 10/1/96 & 15 & & & & & 105 & 10 & 0 & of & 0 & 7 & 7 & 13 & 3.04 & \\
\hline PVT-1 & $10 / 16 / 96$ & 60 & 48 & & $\begin{array}{l}\text { heel } \\
\text { stspo }\end{array}$ & $\begin{array}{r}154 \\
0\end{array}$ & 105 & 10 & 0 & 0 & 0 & 30 & 30 & 52 & 3.07 & \\
\hline & & & space gain ${ }^{-}$ & 0 & lotal & 154 & & & & & & & & & & \\
\hline CLFL Outage & $12 / 15 / 96$ & 290 & $\cdots$ & $\ldots$ & $\ldots$ & $\ldots$ & 105 & 10 & 0 & of & 0 & 143 & 143) & 253 & 3.21 & \\
\hline $\begin{array}{c}\text { FY98 } \\
\text { CLFL Outage }\end{array}$ & 10/1/97 & 114 & & -.. & & -- & 105 & 10 & 0 & of & 0 & 56 & 56 & 99 & 3.27 & \\
\hline Re.Evaluation & $1 / 23 / 98$ & 251 & & $\ldots$ & & $\ldots$ & 105 & 10 & 0 & o] & 0 & 124 & 124 & 219 & 3.39 & \\
\hline $\begin{array}{c}\text { FY99 } \\
\text { Re-Evaluation }\end{array}$ & $10 / 1 / 98$ & 61 & & $\cdots$ & & $\ldots$ & 105 & 10 & 0 & 9 & $\overline{0}$ & 30 & 30 & 53 & 3.42 & \\
\hline Assumed Down & $12 / 1 / 98$ & 304 & & $\ldots$ & & $\ldots$ & 105 & 10 & 0 & 0 & 0 & 150 & 150 & 265 & 3.57 & \\
\hline $\begin{array}{c}\text { FYo0 } \\
\text { Assumed Down }\end{array}$ & $10 / 1 / 99$ & 366 & & $\cdots$ & & $\ldots$ & 705 & To & $\overline{0}$ & 可 & 0 & 180 & 180 & $\overline{319}$ & 3.75 & \\
\hline $\begin{array}{c}\text { FYo1 } \\
\text { Assumed Down }\end{array}$ & $10 / 4 / 00$ & 365 & & $\cdots$ & & $\ldots$ & 105 & 10 & $\overline{0}$ & 0 & $\overline{0}$ & 180 & 180 & $\overline{319}$ & 3.93 & \\
\hline FY02 & 10/1/01 & 365 & $\begin{array}{r}29 \\
29 \\
41 \\
\end{array}$ & $\begin{array}{l}274 \\
239 \\
185\end{array}$ & $\begin{array}{l}c s \\
\text { ds } \\
d s \\
d w \\
\text { swpb } \\
\text { stotal } \\
\end{array}$ & $\begin{array}{r}274 \\
646 \\
500 \\
857 \\
48 \\
2.325 \\
\end{array}$ & 71 & 31 & 0 & 155 & 2.249 & 180 & 2,429 & 4,299 & 6.34 & Al 7.00 cells, stant filing Vault 44 \\
\hline FYo3 & $10 / 1 / 102$ & 365 & $\begin{array}{r}4 \\
29 \\
41 \\
\end{array}$ & $\begin{array}{r}33 \\
741 \\
185 \\
\\
926 \\
\end{array}$ & 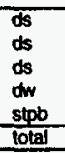 & $\begin{array}{r}89 \\
2,000 \\
500 \\
1,337 \\
619 \\
3,987 \\
\end{array}$ & 130 & 17 & 0 & 285 & 3,889 & 180 & 4,069 & 7,202 & 10.38 & \\
\hline FY04 & $10 / / 1 / 03$ & 366 & $\begin{array}{r}13 \\
25 \\
41 \\
47 \\
\end{array}$ & $\begin{array}{l}200 \\
481 \\
725 \\
143\end{array}$ & $\begin{array}{l}c s \\
d s \\
d s \\
c s \\
d w \\
\text { stpb } \\
\text { lotal } \\
\end{array}$ & $\begin{array}{r}200 \\
1,300 \\
1,957 \\
143 \\
1,902 \\
127 \\
5,629 \\
\end{array}$ & 189 & 21 & 265 & 209 & 5,425 & 180 & 5,605 & 9,922 & 15.95 & At 18.0 cells, start flling Vault in2. \\
\hline FYos & 10/104 & 365 & $\begin{array}{l}25 \\
27 \\
30 \\
38 \\
41 \\
47\end{array}$ & $\begin{array}{l}604 \\
305 \\
900 \\
300 \\
111 \\
333\end{array}$ & $\begin{array}{l}d s \\
c s \\
c s \\
c s \\
d s \\
d s \\
d w \\
d w \\
s \text { spo } \\
\text { lotal } \\
\end{array}$ & $\begin{array}{r}1631 \\
305 \\
900 \\
300 \\
300 \\
900 \\
2.532 \\
266 \\
7,134 \\
\end{array}$ & 391 & 30 & 265 & 335 & 6.706 & 180 & 6,886 & 12,188 & 22.79 & Al24.0 celis, start filing Vault $\$ 3$. \\
\hline
\end{tabular}




\section{Appendix G.3 - Salt Processing (250 cans/yr)}

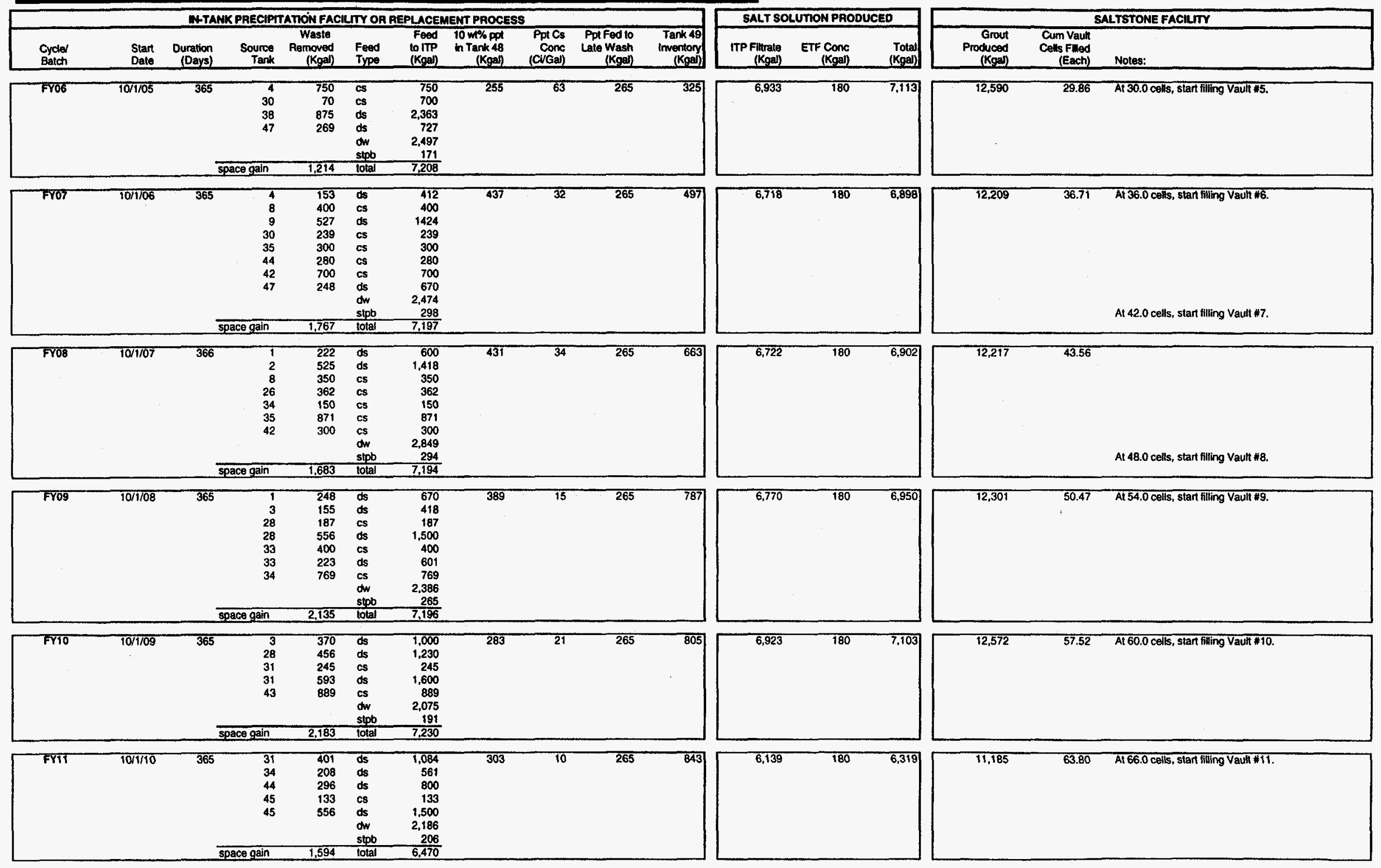




\section{Appendix G.3 - Salt Processing (250 cans/vr)}

\begin{tabular}{|c|c|c|c|c|c|c|c|c|c|c|}
\hline \multicolumn{11}{|c|}{ M-TANK PRECIPTI ATLON FACILITY OR REPLACEMENT PROCESS } \\
\hline $\begin{array}{l}\text { Cycled } \\
\text { Batch }\end{array}$ & $\begin{array}{l}\text { Start } \\
\text { Dale }\end{array}$ & $\begin{array}{c}\text { Duration } \\
\text { (Days) }\end{array}$ & $\begin{array}{r}\text { Source } \\
\text { Tank } \\
\end{array}$ & $\begin{array}{r}\text { Waste } \\
\text { Remeved } \\
\text { (Kgal) }\end{array}$ & $\begin{array}{l}\text { Foed } \\
\text { Type } \\
\end{array}$ & $\begin{array}{l}\text { Feod } \\
0.1 T P \\
\text { (Kgal) } \\
\end{array}$ & $\begin{array}{r}10 \text { m\% pot } \\
n \text { Tant } 48 \\
\text { (Koal) } \\
\end{array}$ & $\begin{array}{r}\text { Ppt Cs } \\
\text { Conc } \\
\text { (CvGal) }\end{array}$ & $\begin{array}{c}\text { Pol Fed to } \\
\text { Lale Wash } \\
\text { (Kgal) }\end{array}$ & 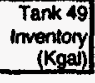 \\
\hline FY12 & $100 / 1 / 11$ & 366 & $\begin{array}{l}10 \\
36 \\
44 \\
45\end{array}$ & $\begin{array}{l}209 \\
187 \\
673 \\
551\end{array}$ & $\begin{array}{l}d s \\
c s \\
d s \\
d s \\
d w \\
d s p b \\
\text { sotal } \\
\text { lotal }\end{array}$ & $\begin{array}{r}563 \\
187 \\
1,816 \\
1,489 \\
2.157 \\
218 \\
6,430\end{array}$ & 321 & 16 & 265 & 899 \\
\hline
\end{tabular}

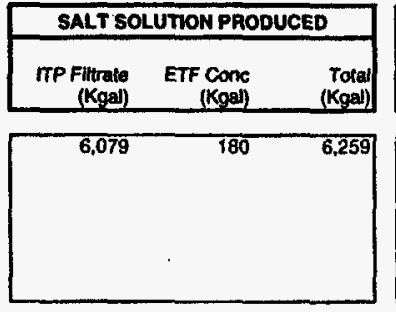

\begin{tabular}{|c|c|c|c|c|c|c|c|c|c|c|}
\hline$F \sqrt{13}$ & $10 / 1 / 12$ & 365 & $\begin{array}{l}27 \\
27 \\
37 \\
29 \\
37 \\
46\end{array}$ & $\begin{array}{l}660 \\
454 \\
222 \\
300 \\
266 \\
500\end{array}$ & $\begin{array}{l}\text { cs } \\
d s \\
c s \\
c s \\
c s \\
c s \\
c s \\
d w \\
\text { stpb } \\
\text { total }\end{array}$ & $\begin{array}{r}660 \\
1,226 \\
600 \\
300 \\
266 \\
500 \\
2,567 \\
299 \\
6,418\end{array}$ & 437 & 26 & 265 & 1,071 \\
\hline
\end{tabular}

\begin{tabular}{|c|c|c|c|c|c|c|c|c|c|c|}
\hline FY14 & $10 / 1 / 13$ & 365 & $\begin{array}{l}29 \\
37 \\
38 \\
46 \\
46\end{array}$ & $\begin{array}{l}903 \\
333 \\
282 \\
389 \\
527\end{array}$ & $\begin{array}{l}c s \\
d s \\
c s \\
c s \\
d s \\
d w \\
\text { stpb }\end{array}$ & $\begin{array}{r}903 \\
900 \\
282 \\
389 \\
1,423 \\
2,128 \\
213 \\
\end{array}$ & 314 & 36 & 265 & 1,120 \\
\hline
\end{tabular}
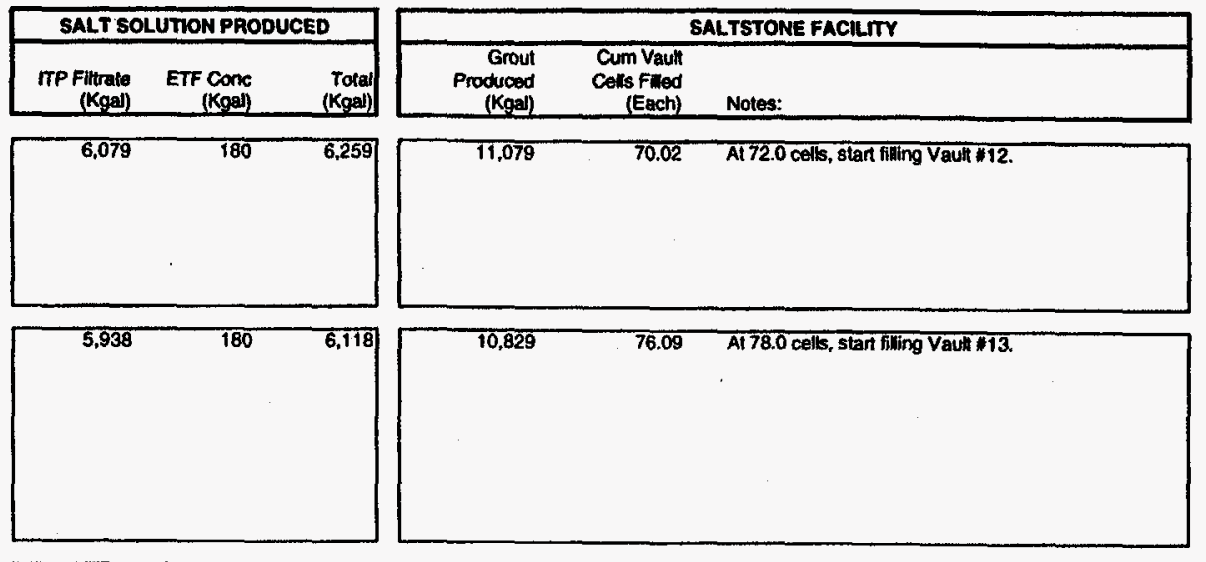

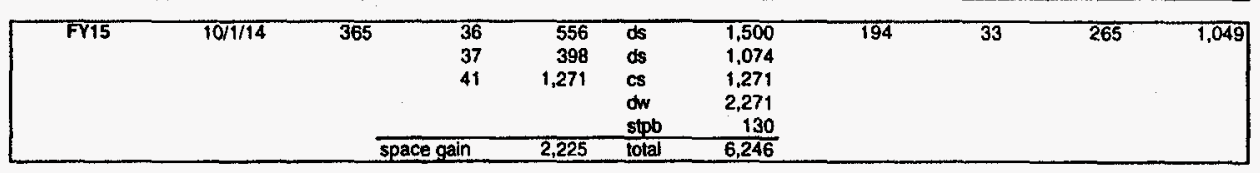
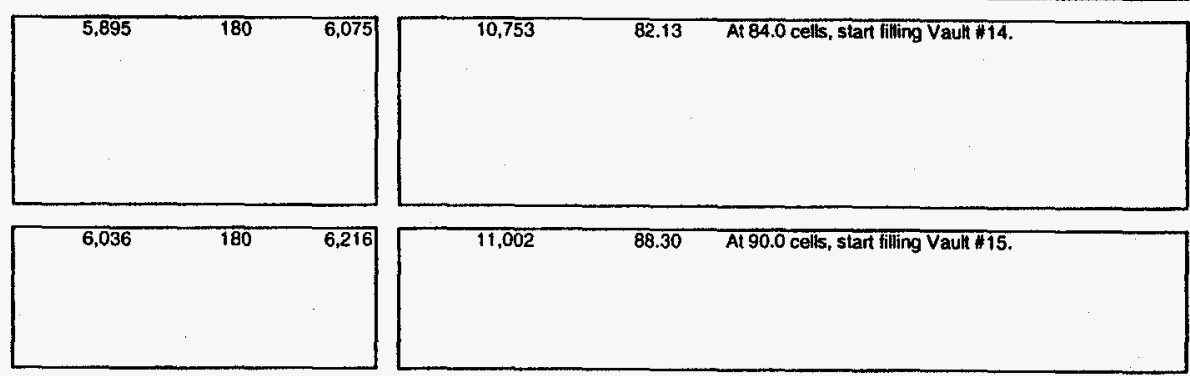

\begin{tabular}{|c|c|c|c|c|c|c|c|c|c|c|}
\hline Fri6 & $10 / 1 / 15$ & 366 & $\begin{array}{l}36 \\
30 \\
38\end{array}$ & $\begin{array}{r}516 \\
1,000 \\
544\end{array}$ & $\begin{array}{l}d s \\
c s \\
d s \\
d s \\
\text { ds } \\
\text { stob } \\
\text { total }\end{array}$ & $\begin{array}{r}1,394 \\
1,000 \\
544 \\
1,792 \\
143 \\
4,873 \\
\end{array}$ & 211 & 64 & 265 & 995 \\
\hline
\end{tabular}
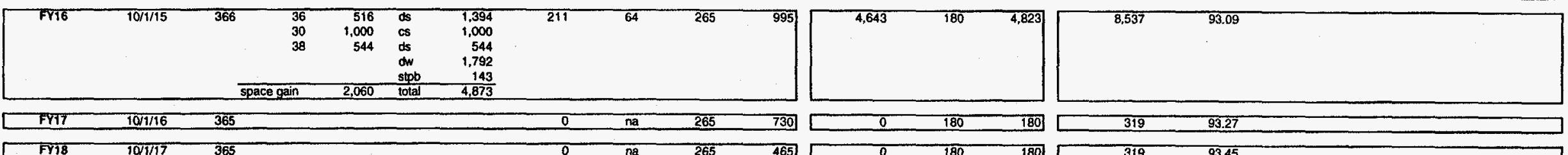

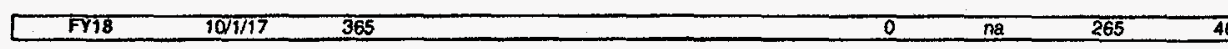

165 $\square$

80

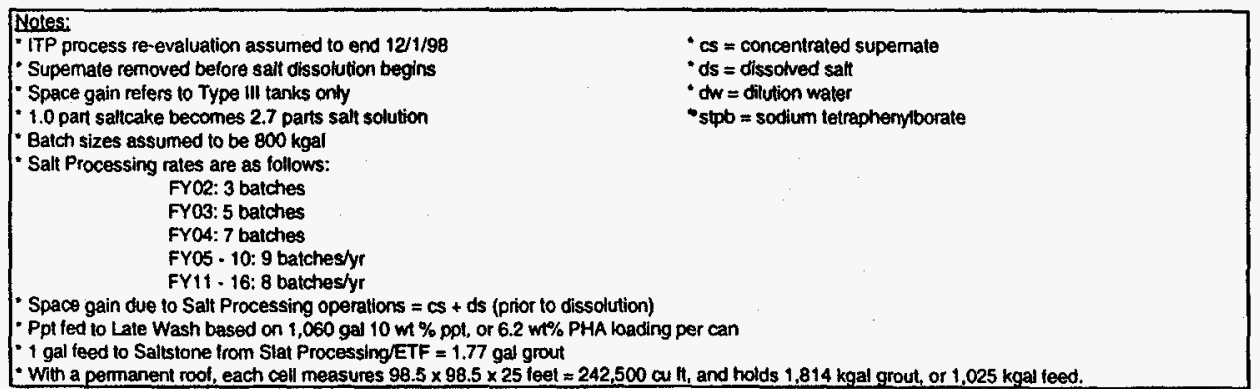


Appendix G.4 - Sludge Processing (250 cans/yr)

\begin{tabular}{|c|c|c|c|c|c|c|c|c|c|c|c|c|c|c|c|c|c|}
\hline & \multicolumn{2}{|c|}{ Waste Removal } & \multicolumn{8}{|c|}{ ESP Pretreatment } & \multicolumn{7}{|c|}{ DWPF Vitrification } \\
\hline $\begin{array}{c}\underline{A} \\
\text { Sludge } \\
\text { Macro- } \\
\text { Batch } \\
\end{array}$ & $\begin{array}{c}\text { B } \\
\text { Source } \\
\text { Tanks } \\
\end{array}$ & $\begin{array}{c}\underline{\mathrm{C}} \\
\text { Sludge } \\
\text { Content } \\
(\mathrm{kg}) \\
\end{array}$ & $\begin{array}{l}\underline{\underline{D}} \\
\text { Alum. } \\
\text { Rern'd } \\
(w t \%) \\
\end{array}$ & $\begin{array}{c}\text { E } \\
\text { Wash } \\
\text { Start } \\
\text { Date } \\
\end{array}$ & $\begin{array}{c}\text { Wash } \\
\text { Wuration } \\
\text { (months) } \\
\end{array}$ & $\begin{array}{c}\underline{\mathbf{G}} \\
\text { Wash } \\
\text { Volume } \\
\text { (kgal) } \\
\end{array}$ & $\begin{array}{c}\underline{\mathrm{H}} \\
\mathrm{Na} \\
\text { (wt\% dry) }\end{array}$ & $\begin{array}{c}! \\
\mathrm{Hg} \\
(w+\% \mathrm{dry})\end{array}$ & $\begin{array}{c}\mathrm{J} \\
\text { Total } \\
\text { Solids } \\
\text { (wt\%) }\end{array}$ & $\begin{array}{c}\underline{\mathrm{K}} \\
\text { Pretreated } \\
\text { Volume } \\
\text { (kgal) } \\
\end{array}$ & $\begin{array}{c}\underline{L} \\
\text { Feed } \\
\text { Volume } \\
\text { (kgal) }\end{array}$ & $\begin{array}{c}\text { M } \\
\text { Start } \\
\text { Feed }\end{array}$ & $\begin{array}{c}\underline{N} \\
\text { Canister } \\
\text { Yield } \\
\end{array}$ & $\begin{array}{c}\underline{\mathbf{o}} \\
\text { Feed } \\
\text { Duration } \\
\text { (years) }\end{array}$ & $\begin{array}{c}\underline{P} \\
\text { Finish } \\
\text { Feed } \\
\end{array}$ & $\begin{array}{c}\underline{Q} \\
\text { Feed } \\
\text { Tank } \\
\end{array}$ & $\begin{array}{c}\text { R } \\
\text { Waste } \\
\text { Loading } \\
\text { (wt \%) }\end{array}$ \\
\hline $1 \mathrm{~A}$ & 51 & na & na & na & na & na & 8.80 & & 16.4 & 491 & $\begin{array}{l}491 \\
\frac{-88}{403} \\
\end{array}$ & $\begin{array}{c}3 / 1 / 96 \\
\text { (Tk } 51 \text { heel) }\end{array}$ & 466 & 2.75 & $8 / 30 / 98$ & 51 & 27.3 \\
\hline $1 \mathrm{~B}$ & $\begin{array}{c}42 \\
\text { total }\end{array}$ & $\frac{220,700}{220,700}$ & na & na & na & na & 7.77 & & 16.5 & 488 & $\begin{array}{l}488 \\
\frac{-75}{413}\end{array}$ & $\begin{array}{c}8 / 30 / 98 \\
\text { (Tk } 42 \text { heel) }\end{array}$ & 428 & 1.71 & $5 / 15 / 00$ & 51 & 28.5 \\
\hline $\begin{array}{c}2 \\
(2 A)\end{array}$ & $\begin{array}{c}8 \\
40 \\
\text { total } \\
\end{array}$ & $\begin{array}{l}182,500 \\
\frac{167,100}{349,600}\end{array}$ & & $8 / 15 / 98$ & 21 & 1,780 & 6.90 & & 16.9 & 582 & $\begin{array}{l}582 \\
\frac{-88}{494} \\
\end{array}$ & $\begin{array}{c}5 / 15 / 00 \\
\text { (Tk 40 heel) }\end{array}$ & 479 & 1.92 & $4 / 15 / 02$ & 40 & 28.6 \\
\hline $\begin{array}{c}3 \\
(2 B)\end{array}$ & $\begin{array}{c}7(70 \%) \\
11 \\
18 \\
19 \\
\text { total } \\
\end{array}$ & $\begin{array}{r}288,960 \\
124,400 \\
20,740 \\
2,794 \\
436,894 \\
\end{array}$ & 75 & $4 / 14 / 00$ & 24 & 1,680 & 6.90 & & 16.5 & 709 & 709 & $4 / 15 / 02$ & 591 & 2.36 & $8 / 25 / 04$ & 51 & 28.8 \\
\hline $\begin{array}{c}4 \\
(3 A)\end{array}$ & $\begin{array}{c}4 \\
7(30 \%) \\
12 \\
14 \\
\text { total }\end{array}$ & \begin{tabular}{r|r|}
65,480 \\
123,840 \\
189,700 \\
4,119 \\
383,139 \\
\end{tabular} & $\begin{array}{l}50 \\
50\end{array}$ & $8 / 25 / 02$ & 24 & 2,340 & 8.90 & & 16.5 & 658 & 658 & $8 / 25 / 04$ & 527 & 2.11 & $10 / 3 / 06$ & 40 & 29.8 \\
\hline $\begin{array}{c}5 \\
(3 B)\end{array}$ & $\begin{array}{c}5 \\
6 \\
13(30 \%) \\
15 \\
21 \\
22 \\
\text { total }\end{array}$ & $\begin{array}{r}57,630 \\
38,710 \\
125,280 \\
165,800 \\
6,393 \\
13,260 \\
407,073 \\
\end{array}$ & $\begin{array}{l}50 \\
50\end{array}$ & $10 / 3 / 04$ & 24 & 1,800 & 6.90 & & 16.5 & 648 & 648 & $10 / 3 / 06$ & 497 & 1.99 & $9 / 28 / 08$ & 51 & 30.8 \\
\hline $\begin{array}{c}6 \\
\text { (4) }\end{array}$ & $\begin{array}{c}13(70 \%) \\
23 \\
47 \\
\text { total }\end{array}$ & $\begin{array}{r}292,320 \\
59,110 \\
137,800 \\
489,230 \\
\end{array}$ & 35 & $9 / 28 / 06$ & 24 & 3,000 & 7.02 & & 16.5 & 852 & 852 & $9 / 28 / 08$ & 740 & 2.96 & $9 / 13 / 11$ & 40 & 27.8 \\
\hline $\begin{array}{c}7 \\
(5)\end{array}$ & $\begin{array}{c}26 \\
32 \\
33 \\
\text { total }\end{array}$ & $\begin{array}{r}154,900 \\
195,600 \\
\underline{62,400} \\
412,900\end{array}$ & 86 & $9 / 13 / 09$ & 24 & 3,050 & 6.93 & 3.00 & 16.5 & 632 & 632 & $9 / 13 / 11$ & $\overline{473}$ & 1.89 & $8 / 4 / 13$ & 51 & $\overline{31.3}$ \\
\hline
\end{tabular}




\section{Appendix G.4 - Sludge Processing (250 cans/yr)}

\begin{tabular}{|c|c|c|c|c|c|c|c|c|c|c|c|c|c|c|c|c|c|}
\hline & \multicolumn{2}{|c|}{ Waste Removal } & \multicolumn{8}{|c|}{ ESP Pretreatment } & \multicolumn{7}{|c|}{ DWPF Vitrification } \\
\hline $\begin{array}{c}\text { A } \\
\text { Sludge } \\
\text { Macro- } \\
\text { Batch } \\
\end{array}$ & $\begin{array}{c}\text { B } \\
\text { Source } \\
\text { Tanks } \\
\end{array}$ & $\begin{array}{c}\mathrm{C} \\
\text { Sludge } \\
\text { Content } \\
\text { (kg) }\end{array}$ & $\begin{array}{l}\text { D } \\
\text { Alum. } \\
\text { Rem'd } \\
\text { (wt \%) }\end{array}$ & $\begin{array}{c}\text { E } \\
\text { Wash } \\
\text { Start } \\
\text { Dale } \\
\end{array}$ & $\begin{array}{c}F \\
\text { Wash } \\
\text { Duration } \\
\text { (months) } \\
\end{array}$ & $\begin{array}{c}\text { Wash } \\
\text { Volume } \\
\text { (kgal) }\end{array}$ & $\begin{array}{c}\text { H } \\
\mathrm{Na} \\
(w+\% \mathrm{dry}) \\
\end{array}$ & $\begin{array}{c}I \\
\mathrm{Hg} \\
(w+\% \mathrm{~d} y) \\
\end{array}$ & $\begin{array}{c}\mathbf{J} \\
\text { Total } \\
\text { Solids } \\
\text { (wt\%) } \\
\end{array}$ & $\begin{array}{c}\underline{K} \\
\text { Pretreated } \\
\text { Volume } \\
\text { (kgal) } \\
\end{array}$ & $\begin{array}{c}\underline{L} \\
\text { Feed } \\
\text { Volume } \\
\text { (kgai) } \\
\end{array}$ & $\begin{array}{l}\text { M } \\
\text { Start } \\
\text { Feed } \\
\end{array}$ & $\begin{array}{c}\text { N } \\
\text { Canister } \\
\text { Yield } \\
\end{array}$ & $\begin{array}{c}\mathrm{Q} \\
\text { Foed } \\
\text { Duration } \\
\text { (years) }\end{array}$ & $\begin{array}{c}\mathrm{P} \\
\text { Finish } \\
\text { Foed } \\
\end{array}$ & $\begin{array}{c}Q \underline{Q} \\
\text { Feed } \\
\text { Tank } \\
\end{array}$ & $\begin{array}{c}\text { B } \\
\text { Waste } \\
\text { Loading } \\
\text { (wt \%) }\end{array}$ \\
\hline $\begin{array}{c}8 \\
(6 A)\end{array}$ & $\begin{array}{c}34 \\
35 \\
39 \\
43 \\
40 \text { heel } \\
\text { total } \\
\end{array}$ & $\begin{array}{r}77,120 \\
139,000 \\
89,470 \\
51,940 \\
? ? ? \\
357,530 \\
\end{array}$ & $\begin{array}{l}61 \\
61\end{array}$ & $8 / 4 / 11$ & 24 & 1,590 & 6.84 & 3.72 & $\overline{16.5}$ & 565 & $\begin{array}{l}565 \\
\frac{88}{653}\end{array}$ & $\begin{array}{c}8 / 4 / 13 \\
\text { (pump dow }\end{array}$ & $\begin{array}{c}467 \\
\text { Tk } 40 \text { heel }\end{array}$ & $0)^{1.87}$ & $6 / 16 / 15$ & 40 & 32.2 \\
\hline $\begin{array}{c}9 \\
(6 B)\end{array}$ & $\begin{array}{c}51 \text { heel } \\
1-3,9-10,36,41 \\
42 \text { heel } \\
\text { Type III's } \\
\text { total } \\
\end{array}$ & $\begin{array}{r}61,278 \\
20,316 \\
47,478 \\
187,871 \\
316,943 \\
\end{array}$ & $\begin{array}{l}48 \\
48\end{array}$ & $6 / 16 / 13$ & 24 & 540 & 6.95 & 1.52 & 16.5 & 449 & 449 & $6 / 16 / 15$ & $\begin{array}{r}416 \\
5,084 \\
\end{array}$ & 1.66 & $2 / 13 / 17$ & 51 & 30.3 \\
\hline
\end{tabular}

\section{Notes:}

A) each macro-batch must be individually tested and confirmed to meet waste qualification specifications

B) the sludge in these tanks will comprise the macro-batch

C) the amount of sludge from each source tank in the macro-batch

D) the amount of aluminum removed from HM sludge (typically $\mathrm{H}$-Area HHW sludge)

E) the date by which washing must start to have the batch ready to feed by the date in Column $L$

F) planned duration of aluminum dissolution, washing, sampling, test glass production, transfer to feed tank and final decant

G) volume of aluminum dissolution decant plus washwater

H) amount of total $\mathrm{Na}$ in washed sludge (dry basis)

1) $\mathrm{wt} \% \mathrm{Hg}$ in the washed sludge (dry basis)

J) total solids (soluble and insoluble) in washed sludge, normally adjusted to $16.5 \mathrm{wt} \%$

K) volume of sludge at given $w t \%$ total solids before heel effects

L) volume of sludge available for feed after adding or subtracting pump heel

M) start feed date based on depletion of previous macro-batch down to pump heel

$\mathrm{N})$ estimated number of canisters produced given the pretreatment as shown

O) column $M$ divided by the planned canister production during the period in which the macro-batch is vitrified

P) column $M$ plus column $N$

Q) macro-batch feed tank

R) weight fraction of glass comprised of sludge oxides assuming nominal salt oxide loading of $6.2 \mathrm{wt} \%$ 


\section{Appendix G.5 - Canister Storage ( 250 cans/yr)}

\begin{tabular}{|c|c|c|c|c|c|c|c|}
\hline $\begin{array}{r}\text { End } \\
\text { of } \\
\text { Year }\end{array}$ & $\begin{array}{l}\text { SRS Cans } \\
\text { Produced } \\
\text { Each Year }\end{array}$ & $\begin{array}{r}\text { Cumulative } \\
\text { SRS Cans } \\
\text { Produced }\end{array}$ & $\begin{array}{r}\text { Cumulative } \\
\text { SRS Cans } \\
\text { in GWSB\#1 }\end{array}$ & $\begin{array}{r}\text { Cumulative } \\
\text { SRS Cans } \\
\text { in GWSB\#2 }\end{array}$ & $\begin{array}{r}\text { SRS Cans Shipped } \\
\text { to Fed. Repository } \\
\text { Each Year }\end{array}$ & $\begin{array}{r}\text { SRS Cans Shipped } \\
\text { to Fed. Repository } \\
\text { Cumulative }\end{array}$ & $\begin{array}{r}\text { Net Cans } \\
\text { Stored at SRS } \\
\text { Each Year }\end{array}$ \\
\hline 1996 & 64 & 64 & 64 & & & & 64 \\
\hline 1997 & 169 & 233 & 233 & & & & 233 \\
\hline 1998 & 250 & 483 & 483 & & & & 483 \\
\hline 1999 & 250 & 733 & 733 & & & & 733 \\
\hline 2000 & 250 & 983 & 983 & & & & 983 \\
\hline 2001 & 250 & 1,233 & 1,233 & & & & 1,233 \\
\hline 2002 & 250 & 1,483 & 1,483 & & & & 1,483 \\
\hline 2003 & 250 & 1,733 & 1,733 & & & & 1,733 \\
\hline 2004 & 250 & 1,983 & 1,983 & & & & 1,983 \\
\hline 2005 & 250 & 2,233 & 2,159 & 74 & & & 2,233 \\
\hline 2006 & 250 & 2,483 & & 324 & & & 2,483 \\
\hline 2007 & 250 & $2,7.33$ & & 574 & & & 2,733 \\
\hline 2008 & 250 & 2,983 & & 824 & & & 2,983 \\
\hline 2009 & 250 & 3,233 & & 1,074 & & & 3,233 \\
\hline 2010 & 250 & 3,483 & & 1,324 & & & 3,483 \\
\hline 2011 & 250 & 3,733 & & 1,574 & & & 3,733 \\
\hline 2012 & 250 & 3,983 & & 1,824 & & & 3,983 \\
\hline 2013 & 250 & 4,233 & & 2,074 & & & 4,233 \\
\hline 2014 & 250 & 4,483 & & 2,324 & & & 4,483 \\
\hline 2015 & 250 & 4,733 & & 2,074 & 500 & 500 & 4,233 \\
\hline 2016 & 250 & 4,983 & & 1,824 & 500 & 1,000 & 3,983 \\
\hline 2017 & 101 & 5,084 & & 1,425 & 500 & 1,500 & 3,584 \\
\hline 2018 & & & & 925 & 500 & 2,000 & 3,084 \\
\hline 2019 & & & & 425 & 500 & 2,500 & 2,584 \\
\hline 2020 & & & 2,084 & 0 & 500 & 3,000 & 2,084 \\
\hline 2021 & & & 1,584 & & 500 & 3,500 & 1,584 \\
\hline 2022 & & & 1,084 & & 500 & 4,000 & 1,084 \\
\hline 2023 & & & 584 & & 500 & 4,500 & 584 \\
\hline 2024 & & & 84 & & 500 & 5,000 & 84 \\
\hline 2025 & & & 0 & & 84 & 5,084 & 0 \\
\hline
\end{tabular}




\section{Appendix G.5 - Canister Storage (250 cans/yr)}

\section{Notes:}

1) GWSB \#1 filling began in April 1996. It has 2,286 canister storage locations, less 121 locations for which the plugs cannot be repaired, less 5 positions being used for storage of non-radioactive test canisters $=2,159$ usable storage locations. However, of the 2,159 usable positions, 450 locations are currently abandoned in place and will need repair/replacement plugs before they will be available for use.

2) GWSB \#1 is expected to reach maximum capacity in FY05. Therefore, GWSB\#2 must be ready to start operations in FY05.

3) GWSB \#2 maximum capacity should minimize close-coupling of DWPF canister production and Repository availability.

4) Per the 5/98 "Accelerating Cleanup Plan: Paths to Closure," this System Plan assumes that canisters can be transported to the Federal Repository at a rate of 500 per year, starting in 2015.

5) A canister load-out facility will be required to move the canisters from the GWSBs to a truck or rail car. Assume one year for design (FY12) and two years for construction (FY13-14).

6) GWSB \#1 will be emptied and available for D\&D in FY25.

7) GWSB \#2 will be emptied and available for D\&D in FY20.

8) This System Plan does not include possible can-in-canister disposition of excess plutonium.

9) This System Plan does not include possible storage of -300 West Valley canisters at SRS. Pending completion of appropriate NEPA activities and DOE-HQ direction to proceed, receipt of West Valley canisters would be incorporated in the HLW System Plan. 


\section{Appendix H - Simplified HLW System Flowsheet}

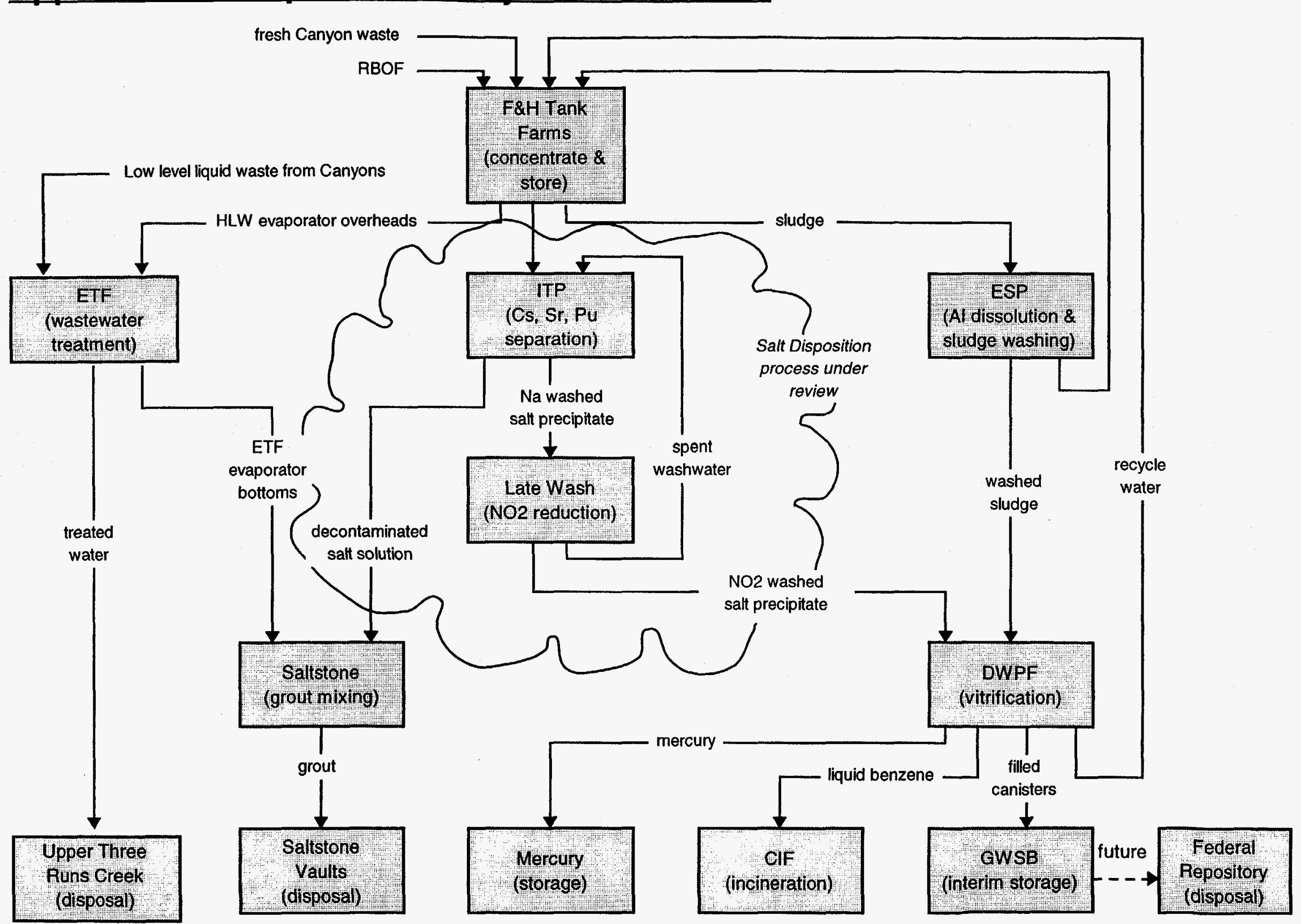




\section{Appendix I-Historical Tank Farm Influents and Effluents}
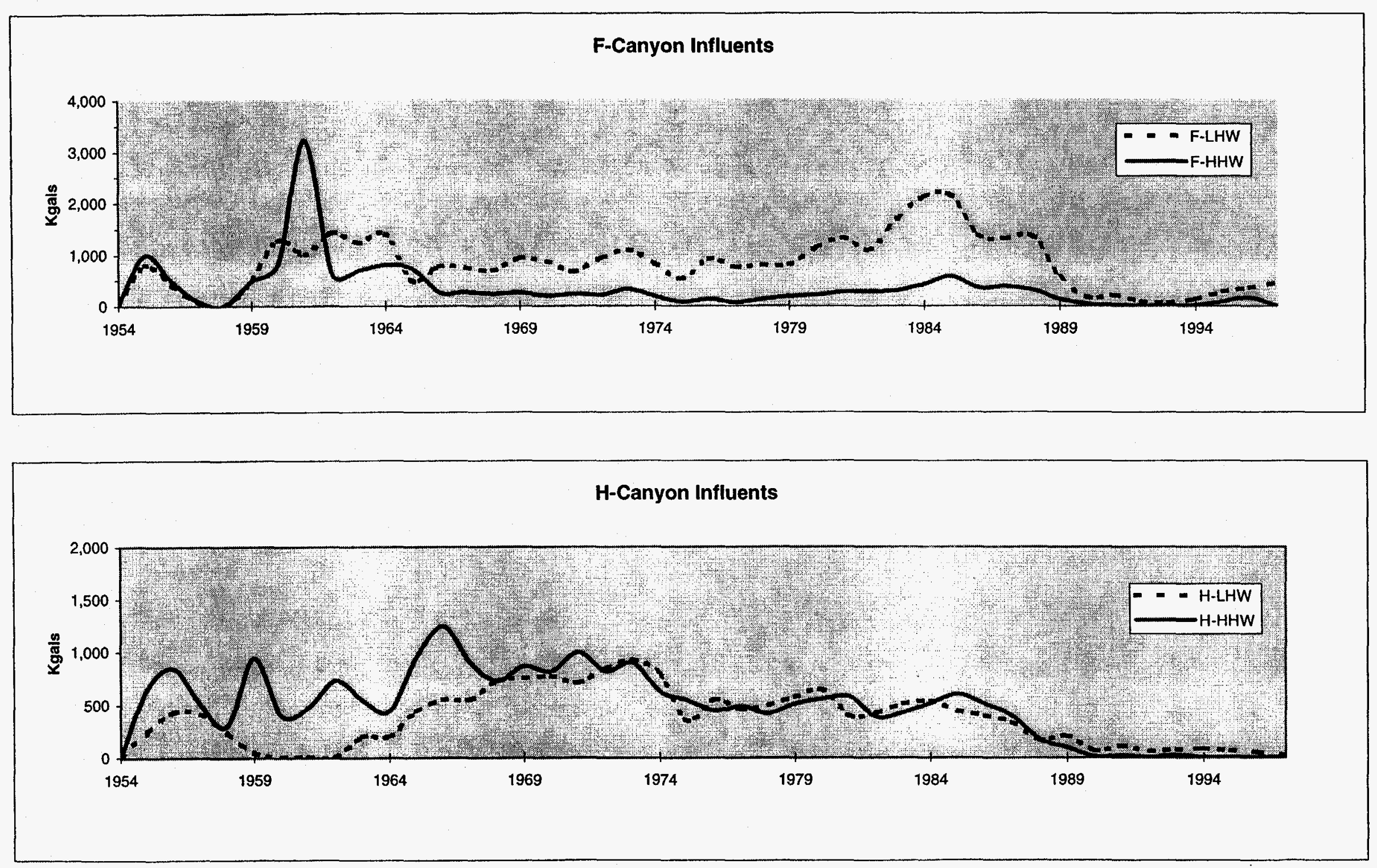


\section{Appendix 1-Historical Tank Farm Influents and Effluents}
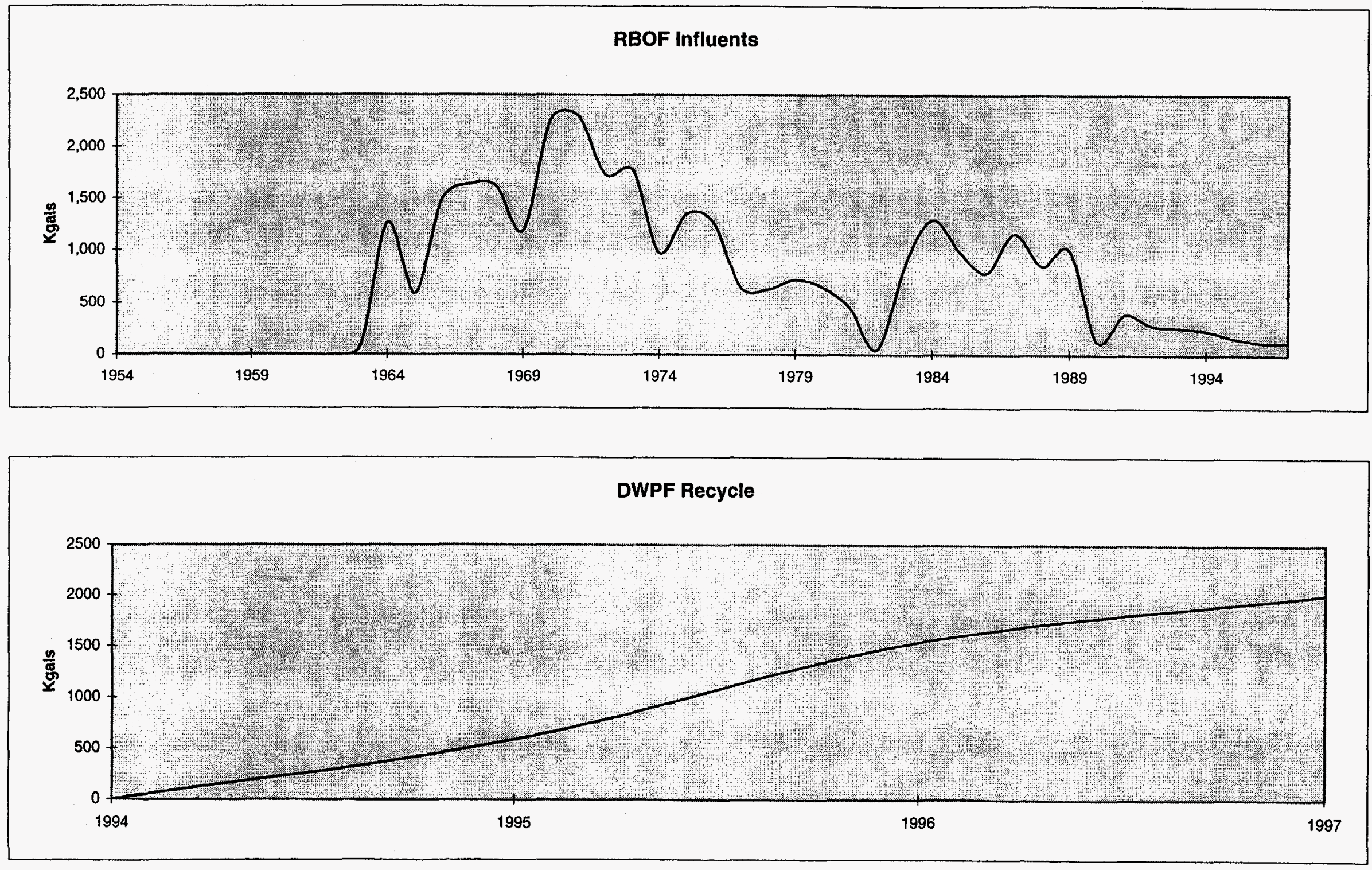


\section{Appendix I - Historical Tank Farm Influents and Effluents}
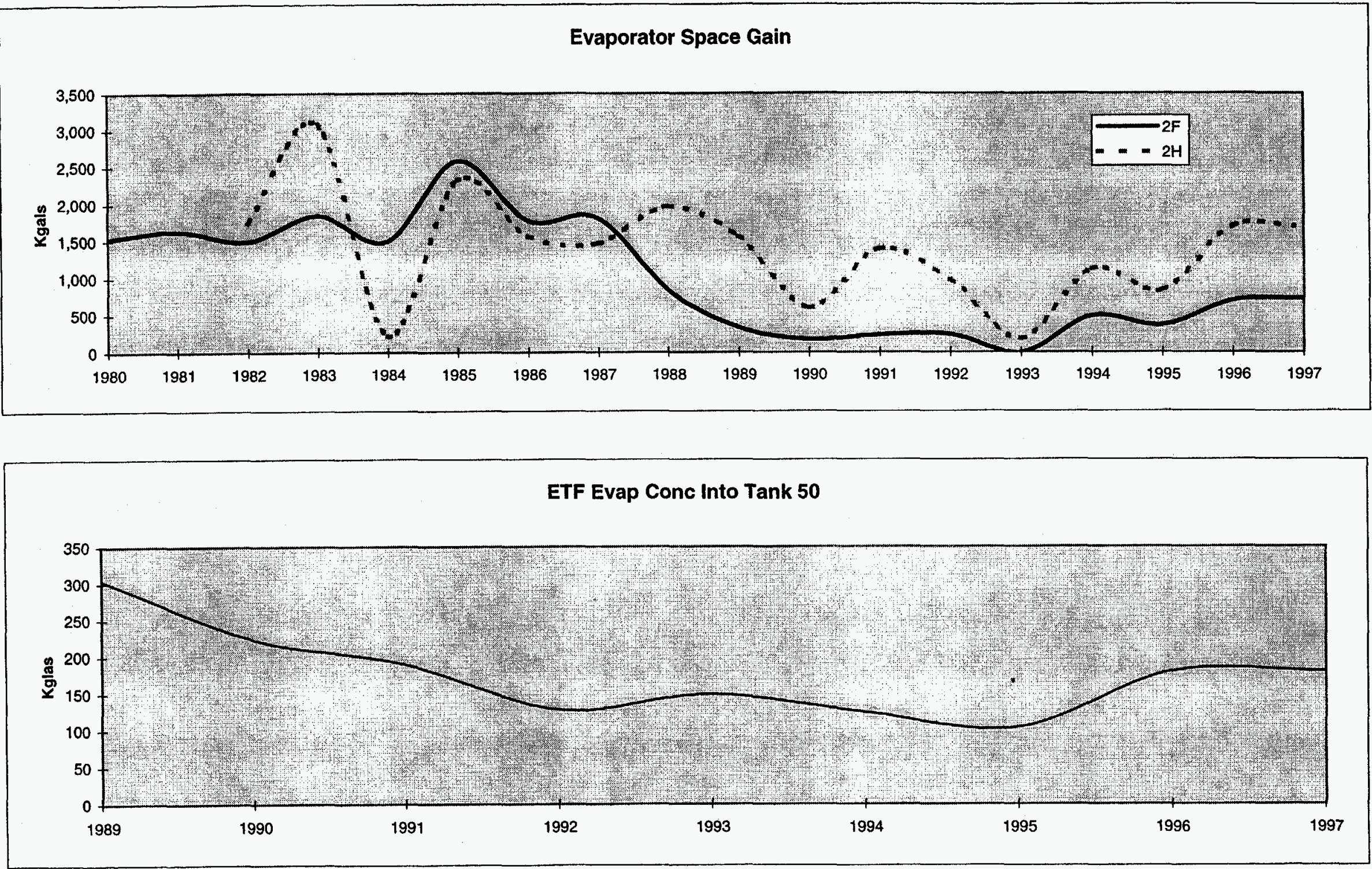


\section{Appendix J.1 - Funding (200 cans/yr)}

\begin{tabular}{|c|c|c|c|c|c|c|c|c|c|c|c|c|}
\hline Project Title & Project \# & FY98 & FY99 & FYO0 & EY01 & FY02 & FY03 & FY04 & FY05 & FY06 & FY07 & FY08 \\
\hline H-Tank Farm & SR-HL01 & 93,734 & 94,795 & 90,244 & 91,966 & 94,989 & 97,924 & 101,156 & 104,494 & 107,932 & 111,484 & 115,153 \\
\hline F-Tank Farm & SR-HLO2 & 51,833 & 55,786 & 59,129 & 60,249 & 62,242 & 63,285 & 65,379 & 67,543 & 69,778 & 72,088 & 74,475 \\
\hline Waste Removal Operations & S SR-HLO3 & 2,016 & 2,190 & 2,362 & 6,936 & 15,261 & 24,339 & 30,560 & 6,857 & 5,865 & 18,050 & 7,684 \\
\hline ITP/ESP & SR-HLO4 & 85,531 & 64,237 & 62,993 & 80,881 & 104,521 & 105,348 & 105,866 & 112,718 & 119,885 & 121,952 & 129,475 \\
\hline Vitrification & SR-HL05 & 125,831 & 144,454 & 142,076 & 155,701 & 161,456 & 161,467 & 163,128 & 169,283 & 175,072 & 180,790 & 186,422 \\
\hline Glass Waste Storage & SR-HL06 & 517 & 526 & 564 & 574 & 849 & 13247 & 39562 & 47298 & 34891 & 1,126 & 1,162 \\
\hline Tank Farm Sevices I & SR-HLO9 & 3,333 & 320 & 0 & 0 & 0 & 0 & 0 & 0 & 0 & 0 & 0 \\
\hline Storm Water Upgrades & SR-HL10 & 1,253 & 4,475 & 6,382 & 0 & 0 & 0 & 0 & 0 & 0 & 0 & 0 \\
\hline Tank Farm Services II & SR-HL11 & 0 & 3,604 & 7,255 & 9,363 & 5,872 & 0 & 0 & 0 & 0 & 0 & 0 \\
\hline Waste Removal Project & $\underline{\text { SR-HL12 }}$ & $\underline{23,026}$ & $\underline{19,520}$ & $\underline{30,848}$ & 118,631 & $\underline{130,348}$ & $\underline{88,285}$ & $\underline{87,343}$ & $\underline{43,240}$ & $\underline{63,133}$ & $\underline{58,313}$ & $\underline{55,757}$ \\
\hline HLWMD Sub-Total & & 387,074 & 389,907 & 401,853 & 524,301 & 575,538 & 553,895 & 592,994 & 551,433 & 576,556 & 563,803 & 570,128 \\
\hline Effluent Treatment Facility & SR-HL07 & 17,353 & 16,920 & 18,853 & 18,156 & 19,255 & 19,534 & 20,341 & 20,956 & 21,567 & 22,272 & 23,000 \\
\hline Saltstone & SR-HLO8 & 7,753 & 1,871 & 2,216 & 8,688 & 9,361 & 15,072 & 25,014 & 23,656 & 36,185 & 36,775 & 26,027 \\
\hline Consol. Incinerator Fac. & $\underline{\text { SR-SW01 }}$ & $\underline{22,168}$ & $\underline{22,875}$ & $\underline{24,310}$ & $\underline{25,020}$ & $\underline{26,745}$ & $\underline{24,618}$ & $\underline{25,046}$ & $\underline{26,177}$ & $\underline{27,442}$ & $\underline{28,320}$ & $\underline{29,2}$ \\
\hline Solid Waste Div. Sub-Tot & & 47,274 & 41,666 & 45,379 & 51,864 & 55,361 & 59,224 & 70,401 & 70,789 & 85,194 & 87,367 & 78,252 \\
\hline Totals & & 4,348 & 31,573 & 447,232 & 76,165 & 630,899 & 613,119 & 663,395 & 622,222 & 661,750 & 651,170 & 648,380 \\
\hline
\end{tabular}




\section{Appendix J.1 - Funding (200 cans/yr)}

\begin{tabular}{|c|c|c|c|c|c|c|c|c|c|c|c|c|}
\hline Project Title & Project \# & FY09 & FY10 & FY11 & FY12 & FY13 & FY14 & FY15 & $\underline{F Y 16}$ & FY17 & FY18 & FY19 \\
\hline H-Tank Farm & SR-HL01 & 118,943 & 122,859 & 126,904 & 93,981 & 86,190 & 89,030 & 91,964 & 77,303 & 79,852 & 82,485 & 85,202 \\
\hline F-Tank Farm & SR-HLO2 & 76,940 & 79,488 & 82,121 & 67,416 & 51,755 & 53,469 & 55,241 & 57,072 & 58,964 & 40,474 & 31,318 \\
\hline Waste Removal & SR-HLO3 & 15,341 & 44,407 & 34,247 & 75,184 & 39,408 & 24,654 & 20,054 & 42,002 & 18,423 & 68,569 & 65,552 \\
\hline ITP/ESP & SR-HLO4 & 132,912 & 144,831 & 132,693 & 139,033 & 155,139 & 154,693 & 166,433 & 161,050 & 158,629 & 173,592 & 180,962 \\
\hline Vitrification & SR-HL05 & 192,797 & 199,098 & 205,309 & 217,199 & 223,774 & 226,126 & 231,374 & 238,282 & 246,102 & 254,896 & 262,524 \\
\hline Glass Waste Storage & SR-HL06 & 1,200 & 1,239 & 1,279 & 1,321 & 1,363 & 1,408 & 3,510 & 3,626 & 3,745 & 3,869 & 3,996 \\
\hline Tank Farm Sevices I & SR-HLO9 & 0 & 0 & 0 & 0 & 0 & 0 & 0 & 0 & 0 & 0 & 0 \\
\hline Storm Water Upgrades & SR-HL10 & 0 & 0 & 0 & 0 & 0 & 0 & 0 & 0 & 0 & 0 & 0 \\
\hline Tank Farm Services II & SR-HL11 & 0 & 0 & 0 & 0 & 0 & 0 & 0 & 0 & 0 & 0 & 0 \\
\hline Waste Removal & $\underline{\mathrm{SR}-\mathrm{HL} 12}$ & $\underline{77,760}$ & $\underline{79,856}$ & $\underline{94,931}$ & $\underline{79,157}$ & 71,074 & $\underline{59,704}$ & $\underline{42,557}$ & $\underline{21.910}$ & $\underline{23,878}$ & $\underline{22,192}$ & 19,905 \\
\hline HLWMD Sub-Total & & 615,893 & 671,778 & 677,484 & 673,291 & 628,703 & 609,084 & 611,133 & 601,245 & 589,593 & 646,077 & 649,459 \\
\hline Effluent Treatment Facility & SR-HL07 & 23,753 & 24,530 & 25,332 & 26,161 & 27,017 & 27,902 & 28,815 & 29,758 & 30,732 & 31,739 & 34,916 \\
\hline Saltstone & SR-HL08 & 32,486 & 42,066 & 43,468 & 37,547 & 29,495 & 44,523 & 46,299 & 47,922 & 49,996 & 32,161 & 23,806 \\
\hline Consol. Incinerator Fac. & SR-SW01 & $\underline{30,160}$ & $\underline{31,125}$ & $\underline{32.122}$ & $\underline{33,150}$ & $\underline{34,212}$ & $\underline{35,308}$ & $\underline{36,439}$ & $\underline{37.607}$ & $\underline{38,813}$ & $\underline{40,058}$ & $\underline{39,803}$ \\
\hline \multicolumn{2}{|l|}{ Solid Waste Div. Sub-Total } & 86,399 & 97,721 & 100,922 & 96,858 & 90,724 & 107,733 & 111,553 & 115,287 & 119,541 & 103,958 & 98,525 \\
\hline Grand Totals & & 702,292 & 769,499 & 778,406 & 770,149 & 719,427 & 716,817 & 722,686 & 716,532 & 709,134 & 750,035 & 747,984 \\
\hline
\end{tabular}




\section{Appendix J.1 - Funding (200 cans/yr)}

\begin{tabular}{|c|c|c|c|c|c|c|c|c|c|c|c|}
\hline Project Title & Project \# & FY20 & FY21 & FY22 & FY23 & FY24 & FY25 & FY26 & FY27 & FY28 & Total \\
\hline $\mathrm{H}$-Tank Farm & SR-HL01 & 68,334 & 50,376 & 24,363 & 0 & 0 & 0 & 0 & 0 & 0 & $2,301,657$ \\
\hline F-Tank Farm & SR-HLO2 & 0 & 0 & 0 & 0 & 0 & 0 & 0 & 0 & 0 & $1,356,045$ \\
\hline Waste Removal & SR-HLO3 & 90,038 & 50,709 & 35,107 & 234,718 & 298,954 & 0 & 0 & 0 & 0 & $1,279,487$ \\
\hline ITP/ESP & SR-HLO4 & 164,458 & 146,295 & 151,154 & 0 & 0 & 0 & 0 & 0 & 0 & $3,255,281$ \\
\hline Vitrification & SR-HL05 & 271,145 & 280,827 & 276,103 & 0 & 0 & 0 & 0 & 0 & 0 & $5,091,236$ \\
\hline Glass Waste Storage & SR-HLO6 & 4,126 & 4,260 & 3,250 & 3,355 & 3,464 & 3,576 & 0 & 0 & 0 & 188,903 \\
\hline Tank Farm Sevices I & SR-HL09 & 0 & 0 & 0 & 0 & 0 & 0 & 0 & 0 & 0 & 3,653 \\
\hline Storm Water Upgrades & SR-HL10 & 0 & 0 & 0 & 0 & 0 & 0 & 0 & 0 & 0 & 12,110 \\
\hline Tank Farm Services II & SR-HL11 & 0 & 0 & 0 & 0 & 0 & 0 & 0 & 0 & 0 & 26,094 \\
\hline Waste Removal & $\underline{\text { SR-HL12 }}$ & $\underline{14,259}$ & 8,001 & $\underline{4,843}$ & $\underline{20,424}$ & 11,652 & $\underline{Q}$ & $\underline{0}$ & $\underline{0}$ & $\underline{0}$ & $1,370,547$ \\
\hline HLWMD Sub-Total & & 612,360 & 540,468 & 494,820 & 258,497 & 314,070 & 3,576 & 0 & 0 & 0 & $14,885,013$ \\
\hline Effluent Treatment Facility & SR-HL07 & 32,780 & 33,854 & 34,963 & 36,108 & 37,291 & 9,628 & 0 & 0 & 0 & 713,486 \\
\hline Saltstone & SR-HL08 & 21,811 & 21,060 & 21,752 & 22,467 & 5,801 & 0 & 0 & 0 & 0 & 715,278 \\
\hline Consol. Incinerator Fac. & SR-SW01 & $\underline{42,670}$ & 44,040 & $\underline{45,455}$ & $\underline{46,915}$ & 48,422 & $\underline{49,978}$ & $\underline{\mathbf{5 1 , 5 8 5}}$ & $\underline{53,244}$ & $\underline{54,948}$ & \\
\hline \multicolumn{2}{|l|}{ Solid Waste Div. Sub-Total } & 97,261 & 98,954 & 102,170 & 105,490 & 91,514 & 59,606 & 51,585 & 53,244 & 54,948 & $2,536,764$ \\
\hline Grand Totals & & 709,621 & 639,422 & 596,990 & 363,987 & 405,584 & 63,182 & 51,585 & 53,244 & 54,948 & $17,421,777$ \\
\hline
\end{tabular}




\section{Appendix J.2 - Milestones (200 cans/yr vs. 250 cans/yr)}

\section{Milestone}

Start up RHLWE

Resume Salt Processing

Close Tank 16

Close Tank 19

Close Tank 18

Tanks 17-20 Cluster Closed

Start up Late Wash/Salt Cell

Complete filling GWSB \#1

2F Evaporator Shut Down

F-Tank Farm Closed

All HLW Vitrified

Last Canister Shipped

All HLW Facilities Closed
All HLW Facilities Closed (except GWSB)

$\begin{array}{cc}200 \text { cans/yr } \\ \text { Date } \\ \text { 6/30/99 } & \begin{array}{c}250 \text { cans/yr } \\ \text { Date }\end{array} \\ \text { FY02 } & 6 / 30 / 99 \\ \text { FY02 } & \text { FY02 } \\ \text { FY03 } & \text { FY02 } \\ \text { FY04 } & \text { FY04 } \\ \text { FY04 } & \text { FY04 } \\ \text { FY05 } & \text { FY03 } \\ \text { FY07 } & \text { FY05 } \\ \text { FY19 } & \text { FY16 } \\ \text { FY20 } & \text { FY16 } \\ \text { FY22 } & \text { FY17 } \\ \text { FY24 } & \text { FY20 } \\ \text { FY25 } & \text { FY25 }{ }^{\star} \\ \text { FY25 } & \text { FY25 }{ }^{\star}\end{array}$

* end date determined by start date of FY15 and ship rate of 500 cans/yr 
Appendix J.3 - Level 1 Schedule (200 cans/yr)

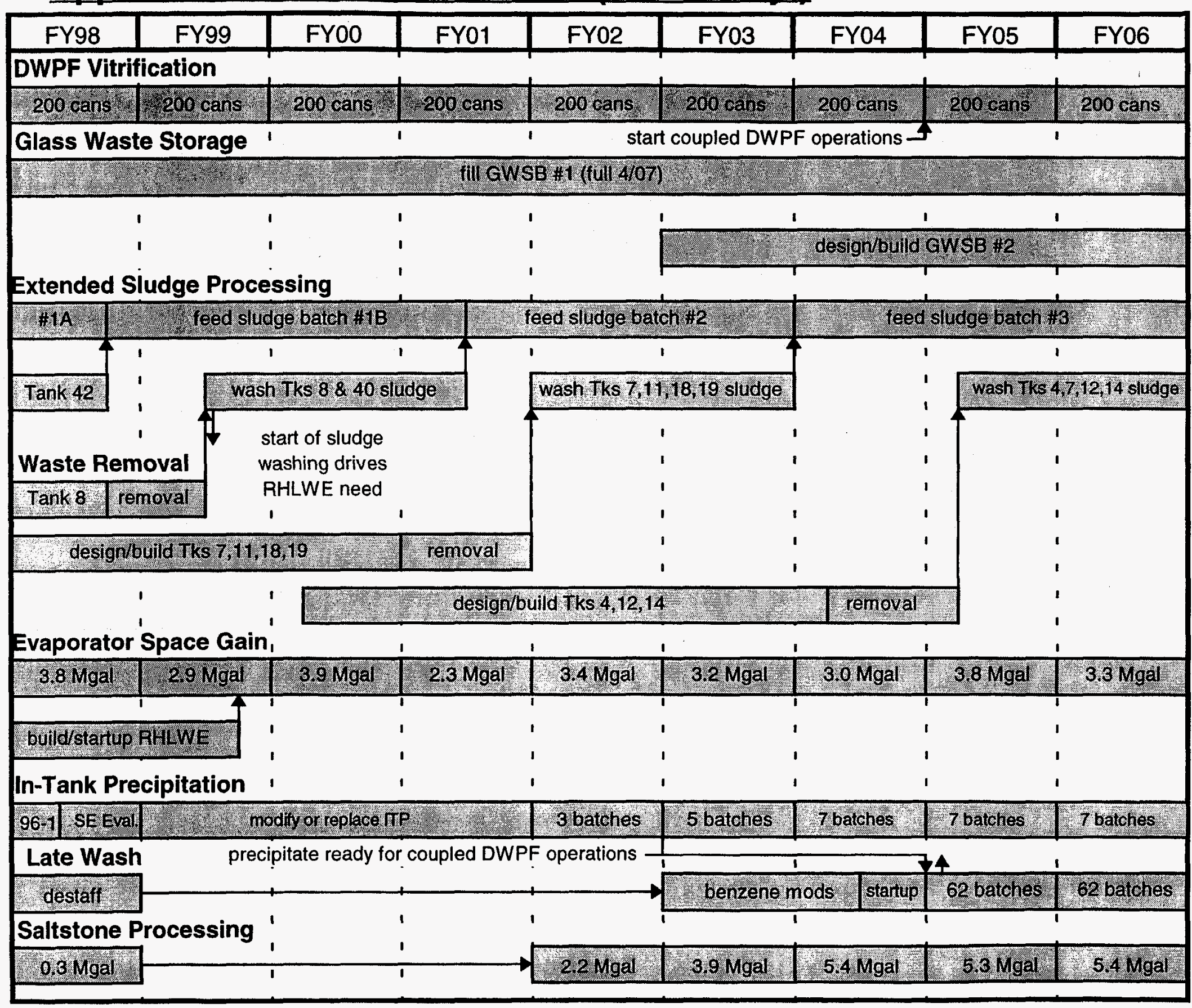




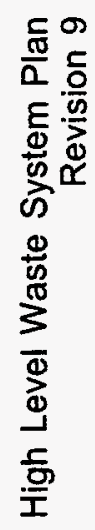

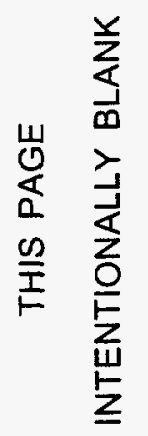

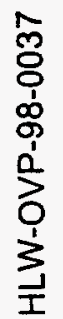




\section{Appendix J.4 - Tank Farm Material Balance (200 cans/yr)}

\begin{tabular}{|c|c|c|c|c|c|c|c|c|c|c|c|}
\hline \multirow{2}{*}{$\begin{array}{l}\text { End of } \\
\text { Mo/rr }\end{array}$} & \multicolumn{7}{|c|}{ Influents } & \multicolumn{4}{|c|}{ Backlog } \\
\hline & F-LHW & $\mathrm{F} \cdot \mathrm{HHW}$ & H-LHW & $\mathrm{H}-\mathrm{HHW}$ & DWPF & ESP & Tank Ww & $\pi k$ & Volume & SGF & Ev \\
\hline \multicolumn{12}{|l|}{ Nov-97 } \\
\hline Dec-97 & 12,993 & 0 & 3,030 & 0 & 165,590 & 아 & 0 & 33 & 351,000 & 0.71 & $2 F$ \\
\hline Jan-98 & 20,000 & 500 & 7,360 & 0 & 165,590 & of & 0 & & & & \\
\hline Feb-98 & 10,500 & 500 & 4,500 & 0 & 165,590 & of & 0 & & & & \\
\hline Mar-98 & 15,500 & 500 & 12,500 & 0 & 165.590 & 0 & 0 & 42 & 182,520 & 0.99 & $2 H$ \\
\hline Apr-98 & 38,500 & 500 & 8,500 & 0 & 165,590 & 0 & 0 & 32 & 421,200 & 0.68 & $2 F$ \\
\hline May-98 & 40,500 & 8,500 & 42,000 & 0 & 165,590 & 0 & 0 & & & & \\
\hline Jun-98 & 49,500 & 8,500 & 33,250 & 0 & 165,590 & of & 0 & 33 & 193,500 & 0.71 & $2 F$ \\
\hline Jut-98 & 10,500 & 500 & 13,250 & 0 & 165,590 & 0 & 0 & & & & \\
\hline Aug-98 & 22,500 & 500 & 13,250 & 0 & 165,590 & 0 & 0 & 32 & 351,000 & 0.68 & $2 F$ \\
\hline Sep-98 & 22,500 & 500 & 13,250 & 0 & 165,590 & 0 & 0 & & & & \\
\hline FY98 & 242,993 & 20,500 & 150,890 & 0 & $1,655,900$ & 0] & 0 & & $1,499,220$ & & \\
\hline Oct-98 & 22,500 & 500 & 13,250 & 14,000 & 163,486 & 0 & 0 & 32 & 175,500 & 0.68 & $2 \mathrm{~F}$ \\
\hline Nov.98 & 15,500 & 500 & 13,250 & 14,000 & 163,486 & 0 & 0 & & & & \\
\hline Dec-98 & 34,500 & 3,500 & 13,250 & 14,000 & 163,486 & of & 0 & & & & \\
\hline Jan-99 & 10,500 & 500 & 10,000 & 14,000 & 163,486 & 0 & 0 & $32 \nmid 35$ & 421,200 & 0.64 & $2 F$ \\
\hline Feb-99 & 22,500 & 500 & 10,000 & 14,000 & 163,486 & 0 & 0 & 33 & 145,000 & 0.71 & $2 \mathrm{~F}$ \\
\hline Mar-99 & 10,500 & 500 & 10,000 & 14,000 & 163,486 & o & 0 & & & & \\
\hline Apr-99 & 22,500 & 500 & 10,000 & 14,000 & 163,486 & 84,762 & 0 & & & & \\
\hline May-99 & 10,500 & 500 & 10,000 & 14,000 & 163,486 & 84,762 & 의 & & & & \\
\hline Jun-99 & 22,500 & 500 & 10,000 & 14,000 & 163,486 & 84,762 & 0 & & & & \\
\hline Jul-99 & 10,500 & 500 & 10,000 & 14,000 & 163,486 & 84,762 & 0 & 30 & 150,000 & 0.31 & $\mathrm{RE}$ \\
\hline Aug.99 & 22,500 & 500 & 10,000 & 14,000 & 163,486 & 84,762 & 0 & 30 & 250,000 & 0.31 & $\mathrm{RE}$ \\
\hline Sep-99 & 10,500 & 500 & 10,000 & 14,000 & 163,486 & 84,762 & 0 & 30 & 300,000 & 0.31 & $\mathrm{RE}$ \\
\hline FY99 & 215,000 & 9,000 & 129,750 & 168,000 & $1,961,832$ & 508,572 & 0 & & $1,441,700$ & & \\
\hline Oct-99 & 22,500 & 500 & 10,000 & 14,000 & 163,486 & 84,762 & 0 & 30 & 388,000 & 0.31 & $\mathrm{RE}$ \\
\hline Nov-99 & 10,500 & 500 & 10,000 & 14,000 & 163,486 & 84,762 & 0 & 39 & 200,000 & 0.56 & $2 F$ \\
\hline Dec-99 & 22,500 & 500 & 10,000 & 14,000 & 163,486 & 84,762 & 0 & 32135 & 200,000 & \begin{tabular}{|l|}
0.64 \\
\end{tabular} & $\mathrm{RE}$ \\
\hline Jan-00 & 10,500 & 500 & 10,000 & 14,000 & 163,486 & 84,762 & 0 & $32+35$ & 200,000 & 0.64 & $\mathrm{RE}$ \\
\hline Feb-00 & 22,500 & 500 & 10,000 & 14,000 & 163,486 & 84,762 & 0 & 42 & 200,000 & 0.45 & $\mathrm{RE}$ \\
\hline Mar-00 & 10,500 & 500 & 10,000 & 14,000 & 163,486 & 84,762 & 0 & 39 & 200,000 & 0.56 & $2 \mathrm{~F}$ \\
\hline Apr.00 & 20,000 & 2,000 & 10,000 & 14,000 & 163,486 & 84,762 & 0 & 39 & 200,000 & 0.56 & $2 \mathrm{~F}$ \\
\hline May-00 & 20,000 & 2,000 & 10,000 & 14,000 & 163,486 & 84,762 & 0 & & & & \\
\hline Jun-00 & 20,000 & 2,000 & 10,000 & 14,000 & 163,486 & 84,762 & 0 & 39 & 200,000 & 0.56 & $2 \mathrm{~F}$ \\
\hline Jul-00 & 20,000 & 2,000 & 10,000 & 15,000 & 163,486 & 84,762 & 0 & 33 & 300,000 & 0.71 & $2 \mathrm{~F}$ \\
\hline Aug.00 & 20,000 & 2,000 & 10,000 & 15,000 & 163,486 & 84,762 & 0 & 39 & 200,000 & 0.56 & $2 \mathrm{~F}$ \\
\hline Sep-00 & 10,000 & 0 & 10,000 & 15,000 & 163,486 & 84,762 & 0 & & & & \\
\hline FYOO & 209,000 & 13,000 & 120,000 & 171,000 & $1,961,832$ & $1,017,144$ & 0 & & $2,288,000$ & & \\
\hline
\end{tabular}
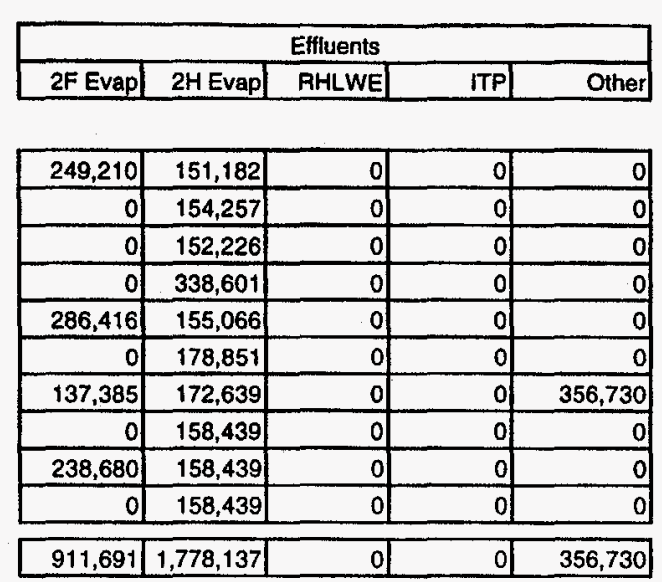

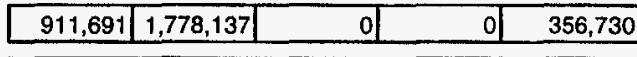

\begin{tabular}{|r|r|r|r|r|}
\hline 119,340 & 147,137 & 0 & 0 & 0 \\
\hline 0 & 147,137 & 0 & 0 & 0 \\
\hline 0 & 147,137 & 0 & 0 & 0 \\
\hline 269,568 & 147,137 & 0 & 0 & 0 \\
\hline 102,950 & 147,137 & 0 & 0 & 0 \\
\hline 0 & 147,137 & 0 & 0 & 0 \\
\hline 25,937 & 193,248 & 0 & 0 & 0 \\
\hline 25,937 & 193,248 & 0 & 0 & 0 \\
\hline 25,937 & 193,248 & 0 & 0 & $-1,070,620$ \\
\hline 25,937 & 110,353 & 129,395 & 0 & 0 \\
\hline 25,937 & 110,353 & 160,395 & 0 & 0 \\
\hline 25,937 & 110,353 & 175,895 & 0 & 0 \\
\hline
\end{tabular}

\begin{tabular}{|l|l|l|l|l|}
\hline 647,481 & $1,793,627$ & 465,685 & & $-1,070,620$ \\
\hline
\end{tabular}

\begin{tabular}{|r|r|r|r|r|}
\hline 25,937 & 110,353 & 203,175 & 0 & 0 \\
\hline 137,937 & 110,353 & 82,895 & 0 & 0 \\
\hline 25,937 & 110,353 & 210,895 & 0 & 0 \\
\hline 25,937 & 110,353 & 210,895 & 0 & 0 \\
\hline 25,937 & 110,353 & 172,895 & 0 & 0 \\
\hline 137,937 & 110,353 & 82,895 & 0 & 0 \\
\hline 137,937 & 110,353 & 82,895 & 0 & 0 \\
\hline 25,937 & 110,353 & 82,895 & 0 & 0 \\
\hline 137,937 & 110,353 & 82,895 & 0 & 0 \\
\hline 238,937 & 110,353 & 82,895 & 0 & 0 \\
\hline 137,937 & 110,353 & 82,895 & 0 & 0 \\
\hline 25,937 & 110,353 & 82,895 & 0 & 0 \\
\hline $1,084,246$ & $1,324,237$ & $1,461,019$ & 0 & 0 \\
\hline
\end{tabular}
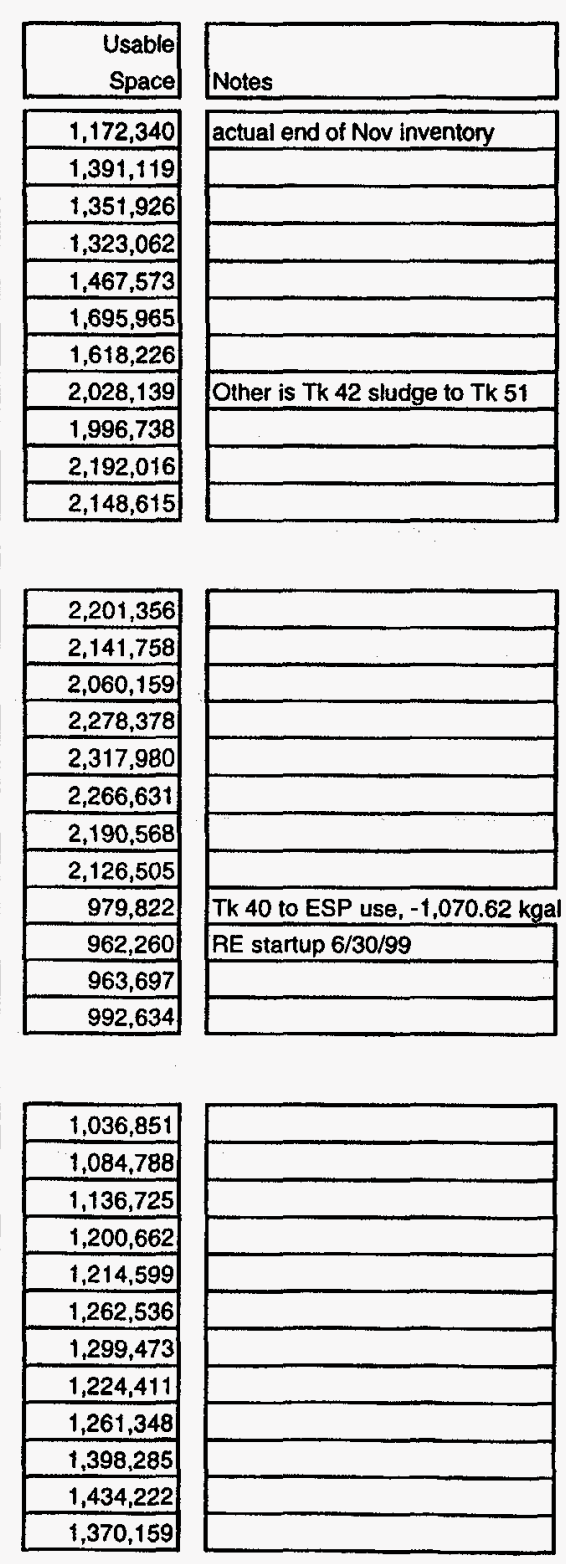


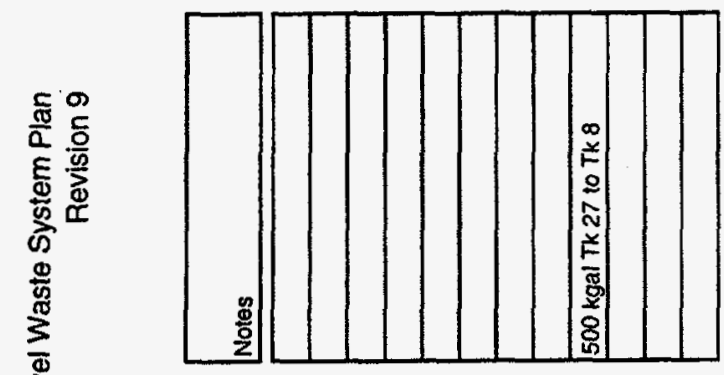

亭

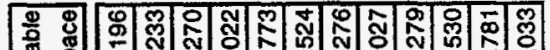

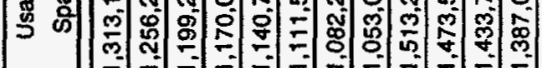
\begin{tabular}{llllllllllll} 
& & & & & & & & & & & \\
\hline
\end{tabular}

鯜

E

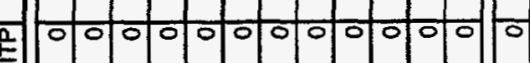

2)

言

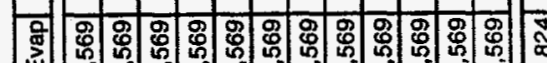

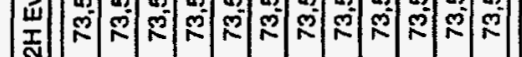

(웡

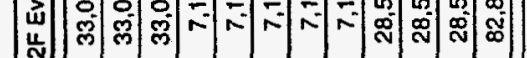

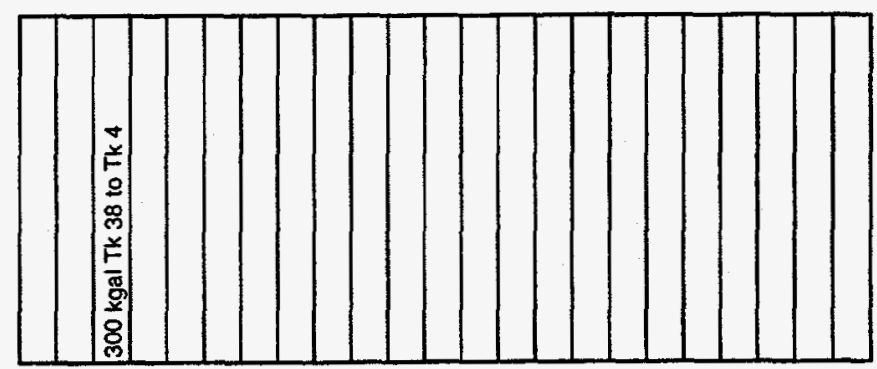

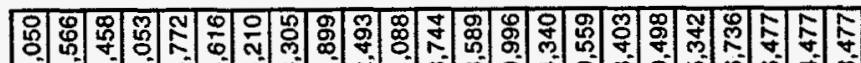
行 $=$ m

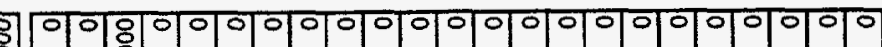

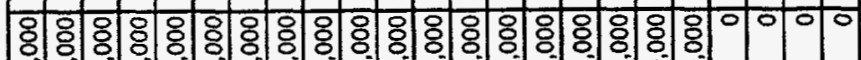

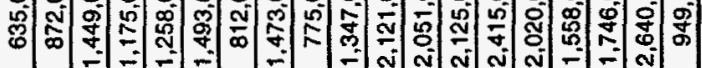

g-5

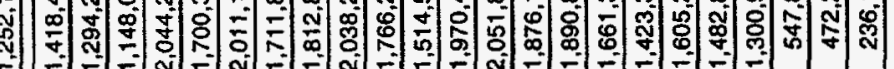

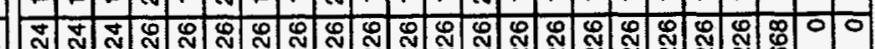
क œ

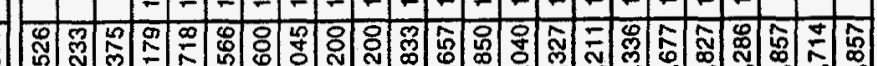

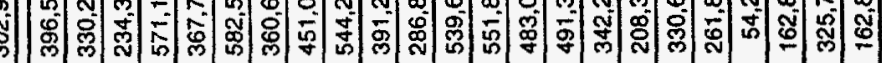
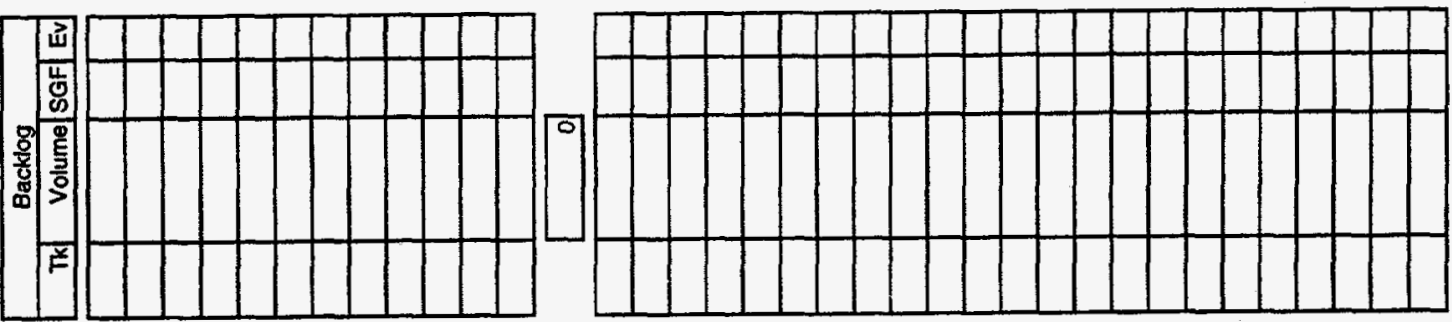

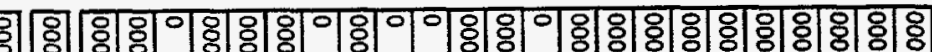

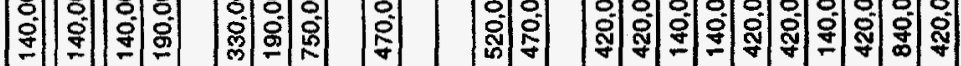
只 Uు री

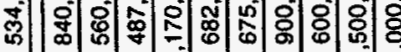

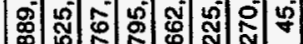

花

(

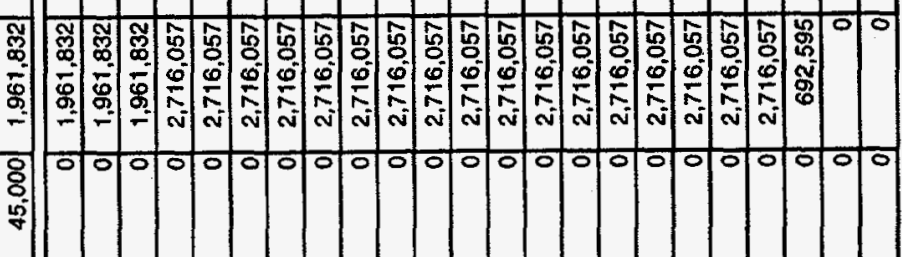

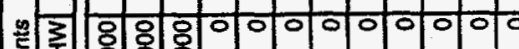
总空

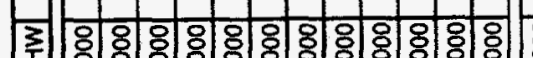

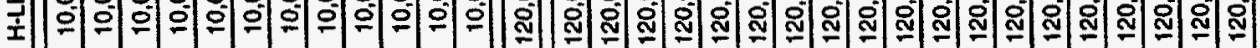

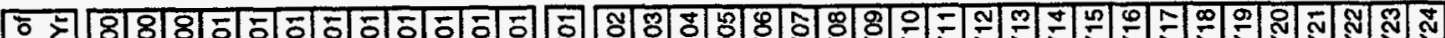

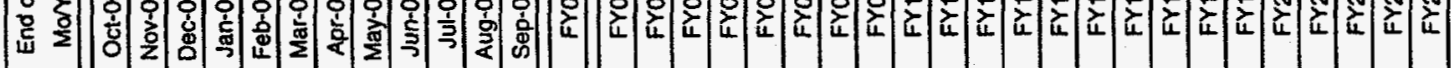




\section{Appendix J.5 - Salt Processing (200 cans/yr)}

\begin{tabular}{|c|c|c|c|c|c|c|c|c|c|c|}
\hline \multicolumn{11}{|c|}{ W-TANK PAECIPTIATION FACILITY OR REPLACEMENT PROCESS } \\
\hline $\begin{array}{l}\text { Cyclel } \\
\text { Batch }\end{array}$ & $\begin{array}{l}\text { Stan } \\
\text { Date }\end{array}$ & $\begin{array}{r}\text { Duration } \\
\text { (Days) }\end{array}$ & $\begin{array}{r}\text { Source } \\
\text { Tank }\end{array}$ & $\begin{array}{c}\text { Waste } \\
\text { Rermoved } \\
\text { (Kgal) }\end{array}$ & $\begin{array}{l}\text { Feed } \\
\text { Type }\end{array}$ & $\begin{array}{l}\text { Feed } \\
\text { tolTP } \\
\text { (Kgal) } \\
\end{array}$ & $\begin{array}{l}0 \text { w'\% popt } \\
\text { in Tank 48 } \\
\text { (Kgall) }\end{array}$ & $\begin{array}{l}\text { Ppt Cs } \\
\text { Conc } \\
\text { (CVGal) }\end{array}$ & $\begin{array}{l}\text { Ppt Fod to } \\
\text { Late Wash } \\
\text { (Kgal) } \\
\end{array}$ & $\begin{array}{r}\text { Tank 49 } \\
\text { Inventory } \\
\text { (Kgal) }\end{array}$ \\
\hline $\begin{array}{l}\text { Fr96 } \\
\text { C1/81 }\end{array}$ & 9/2/95 & 128 & $\begin{array}{l}48 \\
38\end{array}$ & $\begin{array}{l}252 \\
130\end{array}$ & $\begin{array}{l}\text { supr } \\
\text { supr } \\
\text { stpb } \\
\text { total: }\end{array}$ & $\begin{array}{r}252 \\
130 \\
\quad 30 \\
412\end{array}$ & 105 & 10 & 0 & 0 \\
\hline CLFL Outage & $1 / 8 / 96$ & 267 & & & & & 105 & 10 & 0 & 0 \\
\hline FY96 totals & & & ace gain & 382 & & 412 & 105 & 10 & 0 & o] \\
\hline $\begin{array}{c}\text { FY97 } \\
\text { CLFL Outage }\end{array}$ & 10/4/96 & 15 & & & & & 105 & 10 & 0 & 0 \\
\hline PVT-1 & $10 / 16 / 96$ & 60 & $\begin{array}{r}48 \\
\text { ace gain }\end{array}$ & $\overline{0}$ & $\begin{array}{l}\text { neel } \\
\text { stpob } \\
\text { total }\end{array}$ & $\begin{array}{r}154 \\
\quad 0 \\
154\end{array}$ & 105 & 10 & 0 & 0 \\
\hline CLFL Outage & $12 / 15 / 96$ & 290 & $\ldots$ & $\ldots$ & $\ldots$ & $\ldots$ & 105 & 10 & 0 & 0 \\
\hline
\end{tabular}

\begin{tabular}{|c|c|c|c|c|c|c|c|c|}
\hline CLFL Qutage & $12 / 15 / 96$ & 290 & $\ldots$ & $\ldots$ & 105 & 10 & 0 & \\
\hline $\begin{array}{c}\text { FYg8 } \\
\text { CLFL Outage }\end{array}$ & 10/1/97 & 114 & $\cdots$ & $\cdots$ & 105 & 10 & 0 & \\
\hline Re-Evaluation & $1 / 23 / 98$ & 251 & $\ldots$ & $\ldots$ & 105 & 10 & 0 & \\
\hline
\end{tabular}

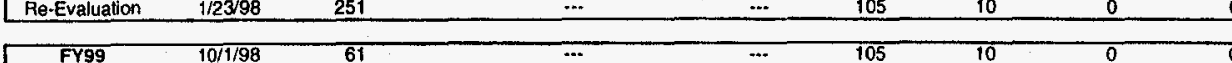

\begin{tabular}{|c|c|c|c|c|c|c|c|}
\hline $\begin{array}{c}\text { FY99 } \\
\text { Re-Evaluation }\end{array}$ & 10/1/98 & 61 & $\cdots$ & $\cdots$ & 105 & 10 & 0 \\
\hline Assumed Down & $12 / 1 / 98$ & 304 & $\ldots$ & $\ldots$ & 105 & 10 & 0 \\
\hline
\end{tabular}$$
\text { Froo }
$$$$
\text { Assumed Down }
$$$$
\begin{array}{|c|ccccccc}
\hline \begin{array}{c}
\text { FYo1 } \\
\text { Assumed Down }
\end{array} & 10 / 1 / 00 & 365 & \cdots & 105 & 10 & 0 \\
\hline
\end{array}
$$

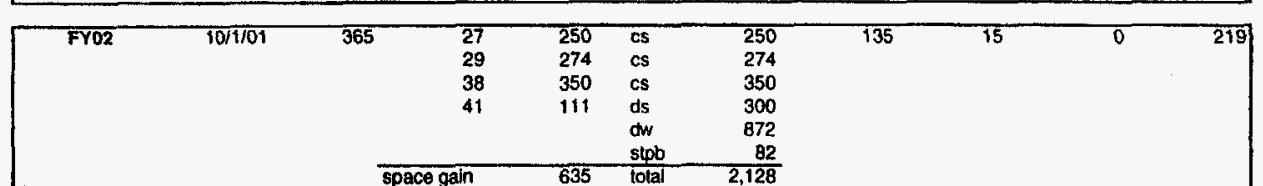

\begin{tabular}{|c|c|c|c|c|c|c|c|c|c|c|}
\hline FYO3 & $10 / 1 / 02$ & $\overline{365}$ & $\begin{array}{r}4 \\
4 \\
11 \\
25 \\
28 \\
29 \\
41\end{array}$ & $\begin{array}{r}346 \\
33 \\
200 \\
162 \\
187 \\
301 \\
222\end{array}$ & $\begin{array}{l}c s \\
d s \\
c s \\
c s \\
c s \\
d s \\
d s \\
d w \\
s p b \\
\text { total }\end{array}$ & $\begin{array}{r}346 \\
89 \\
200 \\
162 \\
187 \\
812 \\
600 \\
1.358 \\
122 \\
3.876\end{array}$ & 200 & 39 & $\overline{0}$ & \\
\hline
\end{tabular}

\begin{tabular}{|c|c|c|c|c|c|c|c|c|c|c|}
\hline FYO4 & $10 / 1 / 03$ & 366 & $\begin{array}{l}25 \\
29 \\
38 \\
41 \\
47\end{array}$ & $\begin{array}{l}185 \\
148 \\
100 \\
873 \\
143\end{array}$ & $\begin{array}{l}\text { ds } \\
d s \\
c s \\
d s \\
c s \\
d w \\
\text { stpb } \\
\text { total }\end{array}$ & $\begin{array}{r}500 \\
400 \\
100 \\
2,357 \\
143 \\
1,740 \\
97 \\
5,337\end{array}$ & 162 & 11 & 0 & \\
\hline
\end{tabular}

\begin{tabular}{|c|c|c|}
\hline \multicolumn{3}{|c|}{ SALT SOLUTONON PRODUCEO } \\
\hline $\begin{array}{l}\text { ITP Fillrate } \\
\text { (Kgal) }\end{array}$ & $\begin{array}{l}\text { ETF Conc } \\
\text { (Kgal) }\end{array}$ & $\begin{array}{c}\text { Tola } \\
\text { (Kgal) }\end{array}$ \\
\hline
\end{tabular}

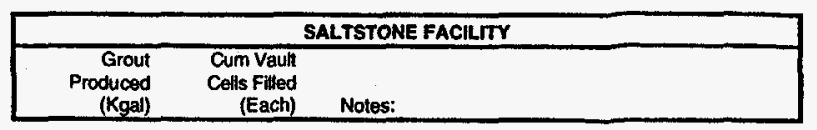

\begin{tabular}{rrr|}
345 & 63 & 408 \\
0 & 132 & 132 \\
\hline
\end{tabular}

\begin{tabular}{lll|}
722 & 2.91 & 2.50 cells filled at start \\
233 & 3.04 & \\
\hline
\end{tabular}

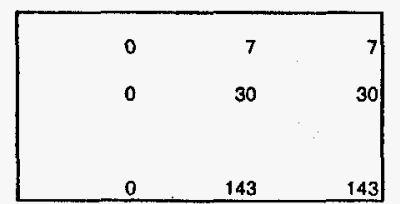

\begin{tabular}{|ll|}
13 & 3.04 \\
52 & 3.07 \\
253 & 3.21 \\
\hline
\end{tabular}
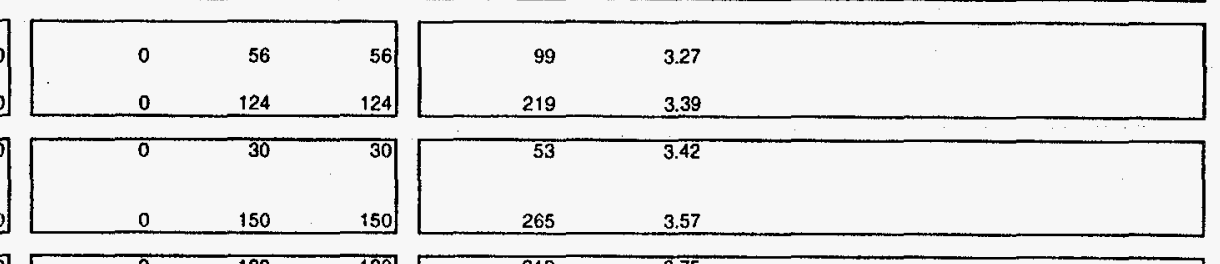

30
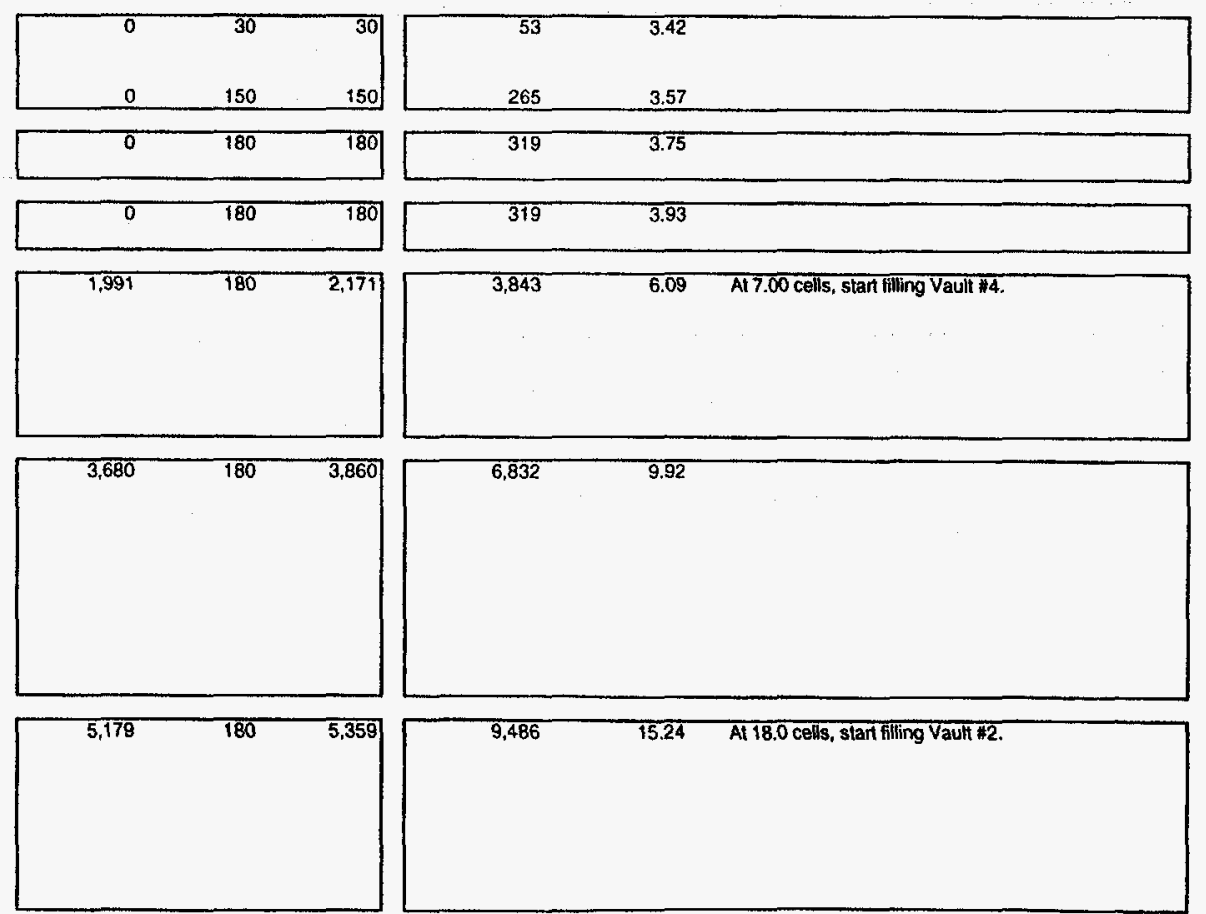


\section{Appendix J.5 - Salt Processing (200 cans/yr)}

\begin{tabular}{|c|c|c|c|c|c|c|c|c|c|c|}
\hline \multicolumn{11}{|c|}{ W-TANK PAECIPITATION FACIIUTY OR REPLACEMENT PROCESS } \\
\hline $\begin{array}{l}\text { Cycled } \\
\text { Balch }\end{array}$ & $\begin{array}{l}\text { Start } \\
\text { Date }\end{array}$ & $\begin{array}{r}\text { Duration } \\
\text { (Days) }\end{array}$ & $\begin{array}{r}\text { Source } \\
\text { Tank } \\
\end{array}$ & $\begin{array}{r}\text { Waste } \\
\text { Removed } \\
\text { (Kgal) }\end{array}$ & $\begin{array}{l}\text { Feed } \\
\text { Type }\end{array}$ & $\begin{array}{l}\text { Foed } \\
\text { foITP } \\
\text { (Kgal) } \\
\end{array}$ & $\begin{array}{r}10 \text { Wroppot } \\
\text { in Tank } 48 \\
\text { (Kgal) } \\
\end{array}$ & $\begin{array}{l}\text { Pplcs } \\
\text { Conc } \\
\text { (Cugal) }\end{array}$ & $\begin{array}{c}\text { Pot Fed to } \\
\text { Lata Wash } \\
\text { (Kgal) }\end{array}$ & 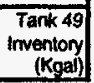 \\
\hline FY05 & 10/1/04 & 365 & $\begin{array}{l}13 \\
21 \\
25 \\
27 \\
29\end{array}$ & $\begin{array}{l}359 \\
117 \\
444 \\
200 \\
531\end{array}$ & $\begin{array}{l}\text { cs } \\
\text { cs } \\
d s \\
c s \\
\text { ds } \\
d \mathbf{d w} \\
\text { stpb } \\
\text { lotal }\end{array}$ & $\begin{array}{r}359 \\
117 \\
1,200 \\
200 \\
1,434 \\
1,869 \\
129 \\
5,308\end{array}$ & 214 & 30 & $\overline{212}$ & 583 \\
\hline
\end{tabular}

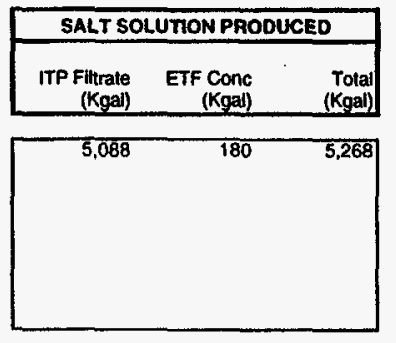

\begin{tabular}{|c|c|}
\hline & SALTSTONE FACILITY \\
\hline $\begin{array}{r}\text { Grout } \\
\text { Prouced } \\
\text { (Kgal) }\end{array}$ & $\begin{array}{c}\text { Cum Vaut } \\
\text { Cells Fillod } \\
\text { (Each) }\end{array} \quad$ Notes: \\
\hline
\end{tabular}

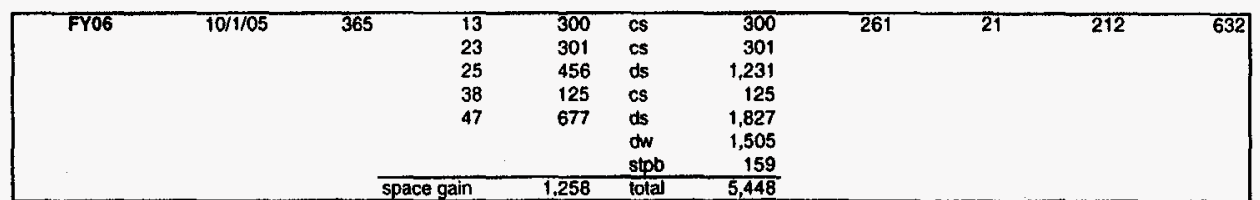
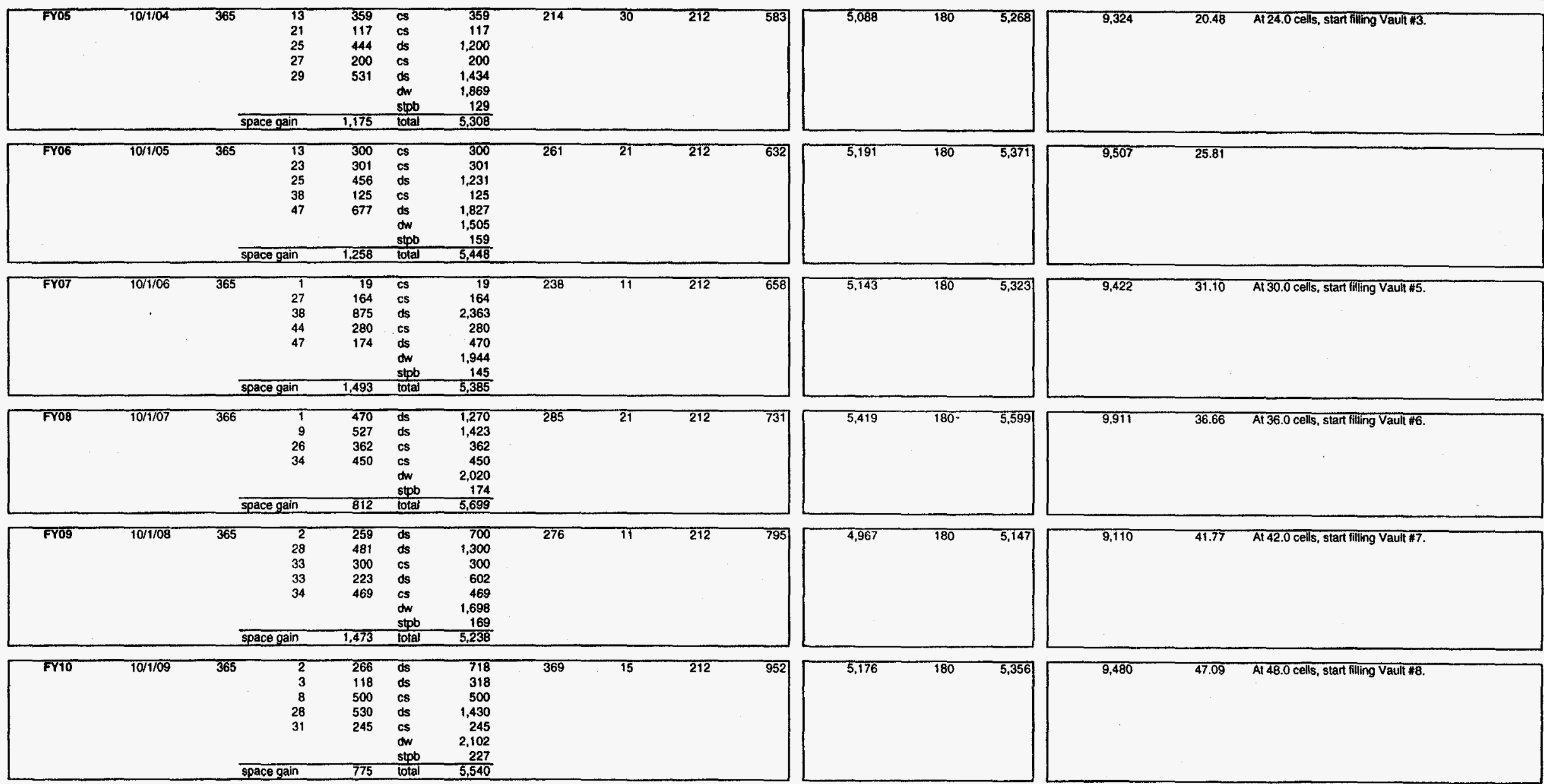

\begin{tabular}{|c|c|c|c|c|c|c|c|c|c|}
\hline FY11 & $10 / 1 / 10$ & 365 & $\begin{array}{r}3 \\
4 \\
30 \\
31 \\
46\end{array}$ & $\begin{array}{l}407 \\
300 \\
800 \\
370 \\
177\end{array}$ & 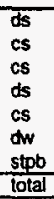 & $\begin{array}{r}1,100 \\
300 \\
800 \\
1,000 \\
177 \\
2,117 \\
105 \\
5,599\end{array}$ & 173 & 51 & 212 \\
\hline
\end{tabular}
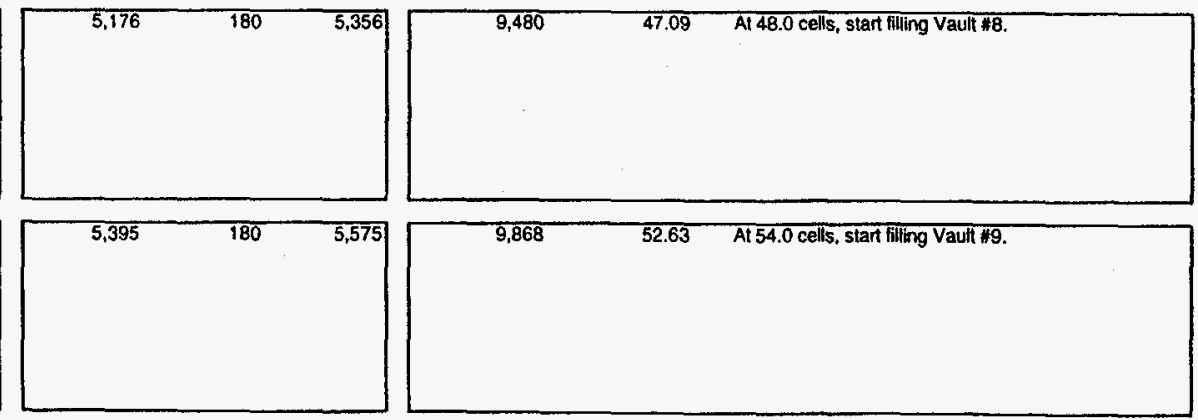


\section{Appendix J.5 - Salt Processing (200 cans/yr)}

\begin{tabular}{|c|c|c|c|c|c|c|c|c|c|c|}
\hline \multicolumn{11}{|c|}{ W-TANK PRECIPTTATION FACIIITT OR REPLACEMENT PROCESS } \\
\hline $\begin{array}{l}\text { Cycclat } \\
\text { Bat }\end{array}$ & $\begin{array}{l}\text { Start } \\
\text { Dale }\end{array}$ & $\begin{array}{c}\text { Duration } \\
\text { (Days) }\end{array}$ & $\begin{array}{r}\text { Source } \\
\text { Tank }\end{array}$ & $\begin{array}{l}\text { Waste } \\
\text { Removed } \\
\text { (Kgal) }\end{array}$ & $\begin{array}{l}\text { Feed } \\
\text { Type }\end{array}$ & $\begin{array}{l}\text { Feod } \\
\text { 101TP } \\
\text { (Kgat) } \\
\end{array}$ & $\begin{array}{l}10 \text { wit\% pot } \\
n \text { Tank 48 } \\
\text { (Kgal) }\end{array}$ & $\begin{array}{l}\text { Pplos } \\
\text { Conch } \\
\text { (CVGall) }\end{array}$ & $\begin{array}{l}\text { Ppif fed to } \\
\text { Late Wash } \\
\text { (Kgal) }\end{array}$ & $\begin{array}{c}\text { Tank 49 } \\
\text { Inventory } \\
\text { (Kgau) }\end{array}$ \\
\hline Fri2 & 10/1/11 & 366 & $\begin{array}{l}30 \\
31 \\
36\end{array}$ & $\begin{array}{r}1,310 \\
624 \\
187\end{array}$ & $\begin{array}{l}\text { cs } \\
d s \\
c s \\
d w \\
s t p b \\
d p t a l\end{array}$ & $\begin{array}{r}1,310 \\
1,684 \\
187 \\
2,188 \\
120 \\
5.489\end{array}$ & 793 & 66 & 212 & 894 \\
\hline
\end{tabular}
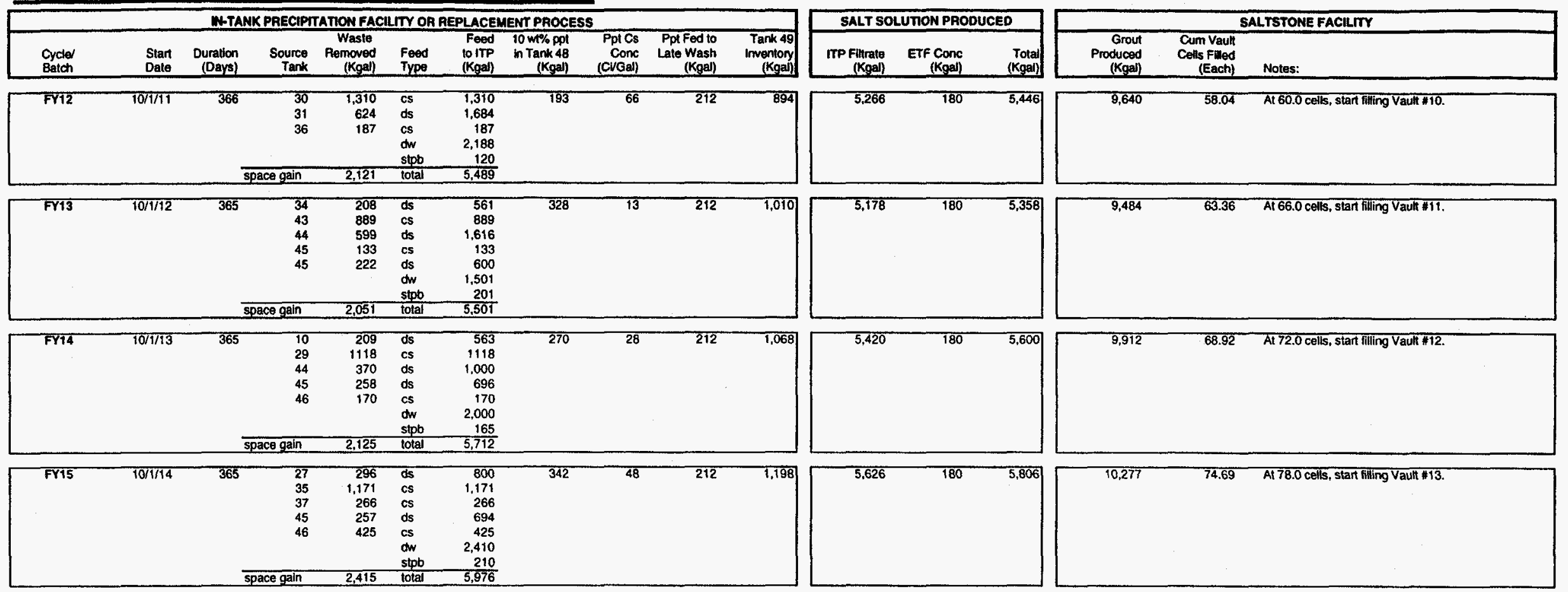

\begin{tabular}{|c|c|c|c|c|c|c|c|c|c|c|}
\hline FY16 & $10 / 1 / 15$ & $\overline{366}$ & $\begin{array}{l}27 \\
41 \\
45 \\
46\end{array}$ & $\begin{array}{r}157 \\
1,197 \\
370 \\
296\end{array}$ & $\begin{array}{l}\text { ds } \\
\text { os } \\
d s \\
d s \\
d w \\
d w \\
\text { sipb } \\
\text { oftal }\end{array}$ & $\begin{array}{r}425 \\
1,197 \\
1,000 \\
800 \\
1,996 \\
142 \\
5.560\end{array}$ & 232 & 9 & 212 & 1,218 \\
\hline
\end{tabular}
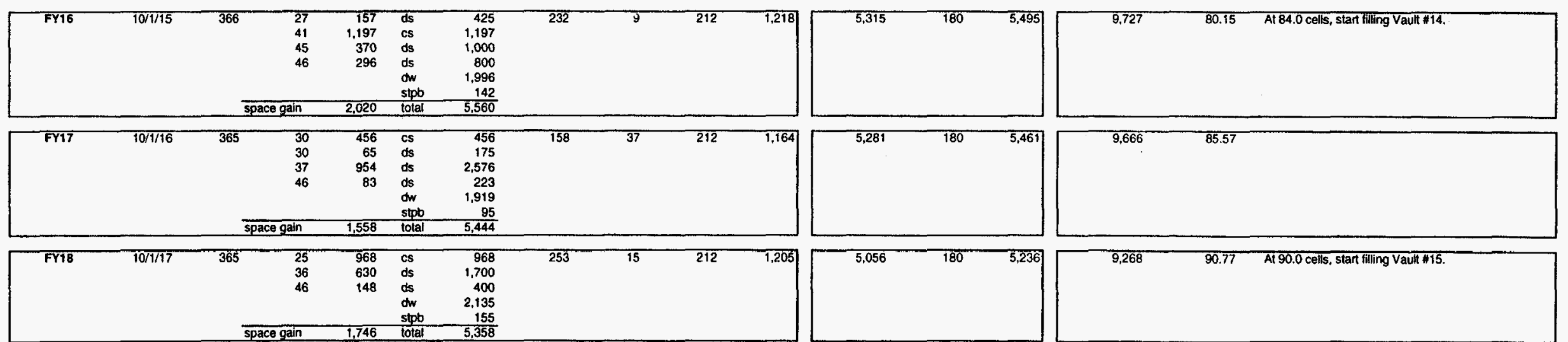

\begin{tabular}{|c|c|c|c|c|c|c|c|c|c|}
\hline FY19 & $10 / 1 / 18$ & 365 & $\begin{array}{l}36 \\
38 \\
42\end{array}$ & $\begin{array}{r}443 \\
1,197 \\
1,000 \\
2,640\end{array}$ & $\begin{array}{l}\text { ds } \\
\text { cs } \\
\text { cs } \\
d w \\
\text { stpb }\end{array}$ & $\begin{array}{r}1,195 \\
1,197 \\
1,000 \\
1,898 \\
166 \\
5,456\end{array}$ & 272 & 24 & 212 \\
\hline
\end{tabular}
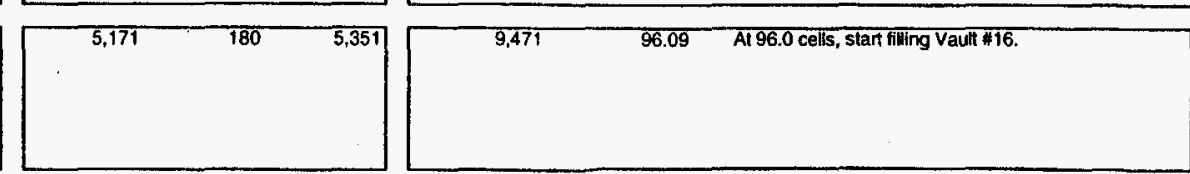


\section{Appendix J.5 - Salt Processing (200 cans/yr)}

\begin{tabular}{|c|c|c|c|c|c|c|c|c|c|c|}
\hline \multicolumn{11}{|c|}{ IH-TANK PRECIPTTATION FACILTTY OR REPLACEMENT PROCESS } \\
\hline $\begin{array}{l}\text { Cycled } \\
\text { Batch }\end{array}$ & $\begin{array}{l}\text { Stant } \\
\text { Date }\end{array}$ & $\begin{array}{c}\text { Duration } \\
\text { (Days) }\end{array}$ & $\begin{array}{r}\text { Source } \\
\text { Tank }\end{array}$ & $\begin{array}{c}\text { Wasle } \\
\text { Removed } \\
(\text { (Kgal) } \\
\end{array}$ & $\begin{array}{l}\text { Feed } \\
\text { Type }\end{array}$ & $\begin{array}{l}\text { Foed } \\
\text { folTP } \\
\text { (Kgal) }\end{array}$ & $\begin{array}{r}10 \text { wto pot } \\
\text { in Tank } 48 \\
\text { (Kgal) }\end{array}$ & $\begin{array}{l}\text { PptCs } \\
\text { Conc } \\
\text { (CvGal) }\end{array}$ & $\begin{array}{l}\text { Ppt Fed to } \\
\text { Late Wash } \\
\text { (Kgal) } \\
\end{array}$ & $\begin{array}{r}\text { Tank 49 } \\
\text { inventory } \\
\text { (Kgal) }\end{array}$ \\
\hline FY20 & $10 / 1 / 19$ & 366 & $\overline{c e g a i n}$ & 949 & $\begin{array}{l}c s \\
\text { dw } \\
\text { stpb } \\
\text { lotal }\end{array}$ & $\begin{array}{r}949 \\
739 \\
38 \\
1,726\end{array}$ & 62 & 10 & 212 & $\overline{T, 115}$ \\
\hline
\end{tabular}

\section{ITP process re-evaluation assumed to end $121 / 98$}

Supemate removed before salt dissolution begins

Space gain reters to Type lil lanks only

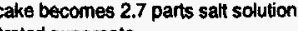

is $\approx$ concentrated supema
ds $=$ dissolved sati

$\mathrm{dw}=$ dilution water

$\operatorname{stpb}=$ sodium tetraphenyiborate

-

ITP limited to 7 batches $y$ ear plus washes as needed

FY02: $\quad 3$ batches $\times 800 \mathrm{Kgalbatch}=2400 \mathrm{Kga}$

FY04. FY20: 7 batches $\times 800$ Kgalbatch $=5600$ Kgally

- Space gain due to ITP operations $=$ cs + ds (prior to dissolution)

Ppt fed to Late Wasth based on 1,060 gal $10 \mathrm{~m} \%$ ppt per can
SALT SOLUTHON PRODUCED

ITP Filtrate ETF Conc Tot

$\begin{array}{ccc}\text { (Kgal) } & \begin{array}{c}\text { ETF Conc } \\ \text { (Kgal) }\end{array} & \begin{array}{r}\text { Total } \\ \text { (Kgal) }\end{array}\end{array}$

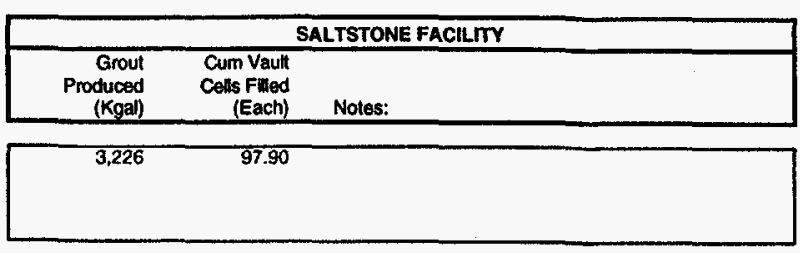




\section{Appendix J.6 - Sludge Processing (200 cans/yr)}

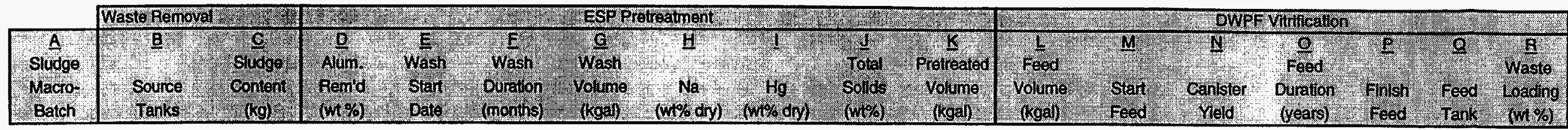

\begin{tabular}{|c|c|c|c|c|c|c|c|c|c|c|c|c|c|c|c|c|c|}
\hline $1 \mathrm{~A}$ & 51 & na & na & na & na & na & 8.80 & & 16.4 & 491 & $\begin{array}{r}491 \\
\frac{-88}{403} \\
\end{array}$ & $\begin{array}{c}\text { 3/1/96 } \\
\text { (Tk } 51 \text { heel) }\end{array}$ & 466 & 2.75 & $11 / 30 / 98$ & 51 & 27.3 \\
\hline 1B & $\begin{array}{c}42 \\
\text { total }\end{array}$ & $\frac{220,700}{220,700}$ & na & na & na & na & 7.77 & 0.76 & 16.5 & 488 & $\begin{array}{l}488 \\
\frac{-75}{413} \\
\end{array}$ & $\begin{array}{c}11 / 30 / 98 \\
\text { (Tk 42 heel) }\end{array}$ & 428 & 2.14 & $1 / 19 / 01$ & 51 & 28.5 \\
\hline $\begin{array}{c}2 \\
(2 A)\end{array}$ & $\begin{array}{c}8 \\
40 \\
\text { total }\end{array}$ & $\begin{array}{r}182,500 \\
167,100 \\
349,600 \\
\end{array}$ & & $4 / 21 / 99$ & 21 & 1,780 & 6.90 & 0.20 & 16.9 & 582 & $\begin{array}{l}582 \\
-88 \\
494 \\
\end{array}$ & $\begin{array}{c}1 / 19 / 01 \\
\text { (Tk 40 heel) }\end{array}$ & 479 & 2.40 & $6 / 13 / 03$ & 40 & 28.6 \\
\hline $\begin{array}{c}3 \\
(2 B)\end{array}$ & $\begin{array}{c}7(70 \%) \\
11 \\
18 \\
19 \\
\text { total }\end{array}$ & \begin{tabular}{r|}
288,960 \\
124,400 \\
20,740 \\
2,794 \\
436,894 \\
\end{tabular} & 75 & $6 / 12 / 01$ & 24 & 1,680 & 6.90 & 1.14 & 16.5 & 709 & 709 & $6 / 13 / 03$ & 591 & 2.96 & $5 / 27 / 06$ & 51 & 28.8 \\
\hline $\begin{array}{c}4 \\
(3 A)\end{array}$ & $\begin{array}{c}4 \\
7(30 \%) \\
12 \\
14 \\
\text { total }\end{array}$ & \begin{tabular}{r|}
65,480 \\
123,840 \\
189,700 \\
4,119 \\
383,139 \\
\end{tabular} & $\begin{array}{l}50 \\
50\end{array}$ & $5 / 27 / 04$ & 24 & 2,340 & 8.90 & 1.30 & 16.5 & 658 & 658 & $5 / 27 / 06$ & 527 & 2.64 & $1 / 14 / 09$ & 40 & 29.8 \\
\hline $\begin{array}{c}5 \\
(3 \mathrm{~B})\end{array}$ & $\begin{array}{c}5 \\
6 \\
13(30 \%) \\
15 \\
21 \\
22 \\
\text { total }\end{array}$ & $\begin{array}{r}57,630 \\
38,710 \\
125,280 \\
165,800 \\
6,393 \\
13,260 \\
407,073 \\
\end{array}$ & $\begin{array}{l}50 \\
50\end{array}$ & $1 / 14 / 07$ & 24 & 1,800 & 6.90 & 2.17 & 16.5 & 648 & 648 & $1 / 14 / 09$ & 497 & 2.49 & $7 / 10 / 11$ & 51 & 30.8 \\
\hline $\begin{array}{c}6 \\
(4)\end{array}$ & $\begin{array}{c}13(70 \%) \\
23 \\
47 \\
\text { total } \\
\end{array}$ & $\begin{array}{r}292,320 \\
59,110 \\
137,800 \\
489,230 \\
\end{array}$ & 35 & $7 / 10 / 09$ & 24 & 3,000 & 7.02 & 1.42 & 16.5 & 852 & 852 & $7 / 10 / 11$ & 740 & 3.70 & $3 / 23 / 15$ & 40 & 27.8 \\
\hline $\begin{array}{c}7 \\
(5)\end{array}$ & $\begin{array}{c}26 \\
32 \\
33 \\
\text { total }\end{array}$ & $\begin{array}{r}154,900 \\
195,600 \\
62,400 \\
412,900\end{array}$ & 86 & $3 / 22 / 13$ & 24 & 3,050 & 6.93 & 3.02 & 16.5 & 632 & 632 & $3 / 23 / 15$ & 473 & 2.37 & $8 / 3 / 17$ & 51 & 31.3 \\
\hline
\end{tabular}




\section{Appendix J.6 - Sludge Processing (200 cans/yr)}

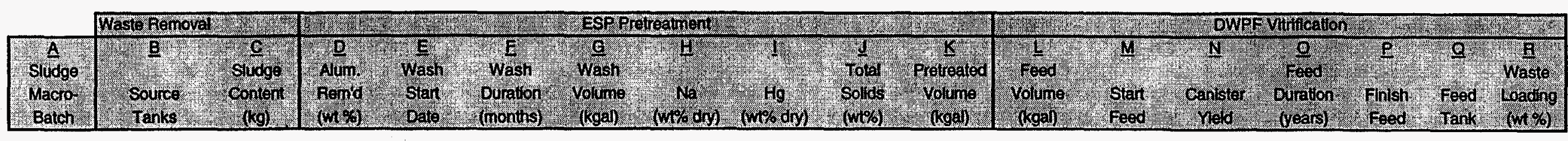

\begin{tabular}{|c|c|c|c|c|c|c|c|c|c|c|c|c|c|c|c|c|c|}
\hline $\begin{array}{c}8 \\
(6 A)\end{array}$ & $\begin{array}{c}34 \\
35 \\
39 \\
43 \\
40 \text { heel } \\
\text { total }\end{array}$ & $\begin{array}{r}77,120 \\
139,000 \\
89,470 \\
51,940 \\
? ? \\
357,530\end{array}$ & $\begin{array}{l}61 \\
61\end{array}$ & $8 / 3 / 15$ & 24 & 1,590 & 6.84 & 3.72 & 16.5 & 565 & $\begin{array}{l}565 \\
\frac{88}{653}\end{array}$ & $\begin{array}{c}8 / 3 / 17 \\
\text { (pump dow }\end{array}$ & $\begin{array}{c}467 \\
k 40 \mathrm{he}\end{array}$ & 2.34 & $12 / 3 / 19$ & 40 & 32.2 \\
\hline $\begin{array}{c}9 \\
(6 \mathrm{~B})\end{array}$ & $\begin{array}{c}51 \text { heel } \\
1-3,9-10,36,41 \\
42 \text { heel } \\
\text { Type Ill's } \\
\text { total }\end{array}$ & $\begin{array}{r}61,278 \\
20,316 \\
47,478 \\
187,871 \\
316,943\end{array}$ & $\begin{array}{l}48 \\
48\end{array}$ & $12 / 3 / 17$ & 24 & 540 & 6.95 & 1.52 & 16.5 & 449 & 449 & $12 / 3 / 19$ & 416 & 2.08 & $1 / 1 / 22$ & 51 & 30.3 \\
\hline Totals & & & & & & 15,780 & & & & & 7,874 & & 5,084 & 25.84 & & & \\
\hline
\end{tabular}

\section{Notes:}

A) each macro-batch must be individually lested and confirmed to meet waste qualification specifications

B) the sludge in these tanks will comprise the macro-batch

C) the amount of sludge in kilograms from each source tank in the macro-batch

D) the amount of aluminum removed from the sludge (typically $\mathrm{H}$-Area HHW sludge)

E) the date by which washing must start to have the batch ready to feed by the date in column L

F) planned duration of aluminum dissolution, washing, sampling, test glass production, transfer to feed tank and final decant

G) volume of aluminum dissolution and washwater decants

H) amount of total $\mathrm{Na}$ in washed sludge (dry basis)

I) $\mathrm{wt} \% \mathrm{Hg}$ in the washed sludge (dry basis), target max is <3 $\mathrm{wt} \%$

J) total solids (soluble and insoluble) in washed sludge, normally adjusted to $16.5 \mathrm{wt} \%$

K) volume of sludge at given wt \% total solids before heel effects

L) volume of sludge available for feed after adding or subtracting pump heel

M) start feed date based on depletion of previous macro-batch down to pump heel

N) estimated number of canisters produced given the pretreatment as shown

O) column $N$ divided by the planned canister production during the period in which the macro-batch is vitrified

P) column M plus column $O$

Q) macro-batch feed tank

R) weight fraction of glass comprised of sludge oxides assuming nominal salt oxide loading of $6.2 \mathrm{wt} \%$ 


\section{Appendix J.7 - Canister Storage (200 cans/yr)}

\begin{tabular}{|c|c|c|c|c|c|c|c|}
\hline $\begin{array}{r}\text { End } \\
\text { of } \\
\text { Year }\end{array}$ & $\begin{array}{l}\text { SRS Cans } \\
\text { Produced } \\
\text { Each Year }\end{array}$ & $\begin{array}{r}\text { Cumulative } \\
\text { SRS Cans } \\
\text { Produced }\end{array}$ & $\begin{array}{r}\text { Cumulative } \\
\text { SRS Cans } \\
\text { in GWSB\#1 }\end{array}$ & $\begin{array}{r}\text { Cumulative } \\
\text { SRS Cans } \\
\text { in GWSB\#2 }\end{array}$ & $\begin{array}{r}\text { SRS Cans Shipped } \\
\text { to Fed. Repository } \\
\text { Each Year }\end{array}$ & $\begin{array}{r}\text { SRS Cans Shipped } \\
\text { to Fed. Repository } \\
\text { Cumulative }\end{array}$ & $\begin{array}{r}\text { Net Cans } \\
\text { Stored at SRS } \\
\text { Each Year }\end{array}$ \\
\hline 1996 & 64 & 64 & 64 & & & & 64 \\
\hline 1997 & 169 & 233 & 233 & & & & 233 \\
\hline 1998 & 200 & 433 & 433 & & & & 433 \\
\hline 1999 & 200 & 633 & 633 & & & & 633 \\
\hline 2000 & 200 & 833 & 833 & & & & 833 \\
\hline 2001 & 200 & 1,033 & 1,033 & & & & 1,033 \\
\hline 2002 & 200 & 1,233 & 1,233 & & & & 1,233 \\
\hline 2003 & 200 & 1,433 & 1,433 & & & & 1,433 \\
\hline 2004 & 200 & 1,633 & 1,633 & & & & 1,633 \\
\hline 2005 & 200 & 1,833 & 1,833 & & & & 1,833 \\
\hline 2006 & 200 & 2,033 & 2,033 & & & & 2,033 \\
\hline 2007 & 200 & 2,233 & 2,159 & 74 & & & 2,233 \\
\hline 2008 & 200 & 2,433 & & 274 & & & 2,433 \\
\hline 2009 & 200 & 2,633 & & 474 & & & 2,633 \\
\hline 2010 & 200 & 2,833 & & 674 & & & 2,833 \\
\hline 2011 & 200 & 3,033 & & 874 & & & 3,033 \\
\hline 2012 & 200 & 3,233 & & 1,074 & & & 3,233 \\
\hline 2013 & 200 & 3,433 & & 1,274 & & & 3,433 \\
\hline 2014 & 200 & 3,633 & & 1,474 & & & 3,633 \\
\hline 2015 & 200 & 3,833 & & 1,174 & 500 & 500 & 3,333 \\
\hline 2016 & 200 & 4,033 & & 874 & 500 & 1,000 & 3,033 \\
\hline 2017 & 200 & 4,233 & & 574 & 500 & 1,500 & 2,733 \\
\hline 2018 & 200 & 4,433 & & 274 & 500 & 2,000 & 2,433 \\
\hline 2019 & 200 & 4,633 & 2,133 & 0 & 500 & 2,500 & 2,133 \\
\hline 2020 & 200 & 4,833 & 1,833 & & 500 & 3,000 & 1,833 \\
\hline 2021 & 200 & 5,033 & 1,533 & & 500 & 3,500 & 1,533 \\
\hline 2022 & 51 & 5,084 & 1,084 & & 500 & 4,000 & 1,084 \\
\hline 2023 & & & 584 & & 500 & 4,500 & 584 \\
\hline 2024 & & & 84 & & 500 & 5,000 & 84 \\
\hline 2025 & & & 0 & & 84 & 5,084 & 0 \\
\hline
\end{tabular}




\section{Appendix J.7 - Canister Storage (200 cans/yr)}

\section{Notes:}

1) GWSB \#1 filling began in April 1996. It has 2,286 canister storage locations, less 121 locations for which the plugs cannot be repaired, less 5 positions being used for storage of non-radioactive test canisters $=2,159$ usable storage locations. However, of the 2,159 usable positions, 450 locations are currently abandoned in place and will need repair/replacement plugs before they will be available for use.

2) GWSB \#1 is expected to reach maximum capacity in FY07. Therefore, GWSB\#2 must be ready to start operations in FY07.

3) GWSB \#2 maximum capacity should minimize close-coupling of DWPF canister production and Repository availability.

4) Per the 5/98 "Accelerating Cleanup Plan: Paths to Closure," this System Plan assumes that canisters can be transported to the Federal Repository at a rate of 500 per year, starting in 2015.

5) A canister load-out facility will be required to move the canisters from the GWSBs to a truck or rail car.

Assume one year for design (FY12) and two years for construction (FY13-14).

6) GWSB \#1 will be emptied and available for D\&D in FY25.

7) GWSB \#2 will be emptied and available for D\&D in FY19.

8) This System Plan does not include possible can-in-canister disposition of excess plutonium.

9) This System Plan does not include possible storage of -300 West Valley canisters at SRS. Pending completion of appropriate NEPA activities and DOE-HQ direction to proceed, receipt of West Valley canisters would be incorporated in the HLW System Plan. 
